Helena Ferreira Nunes

\title{
Responsabilidade Civil e a Transfusão de Sangue
}

Dissertação apresentada ao Departamento de Clínica Médica da Faculdade de Medicina da Universidade de São Paulo para obtenção de título de mestre em Ciências

Programa de: Ciências Médicas

Área de concentração: Distúrbios do Crescimento Celular, Hemodinâmicos e da Hemostasia

Orientador: Prof. Dr. Dalton de Alencar Fischer Chamone

São Paulo 2010 
Dados Internacionais de Catalogação na Publicação (CIP)

Preparada pela Biblioteca da

Faculdade de Medicina da Universidade de São Paulo

Creprodução autorizada pelo autor

\section{Nunes, Helena Ferreira}

Responsabilidade civil e a transfusão de sangue / Helena Ferreira Nunes.. -São Paulo, 2010.

Dissertação(mestrado)--Faculdade de Medicina da Universidade de São Paulo. Programa de Ciências Médicas. Área de concentração: Distúrbios do Crescimento Celular, Hemodinâmicos e da Hemostasia.

Orientador: Dalton de Alencar Fischer Chamone.

Descritores: 1.Transfusão de sangue 2.Responsabilidade civil 3.Serviço de hemoterapia 4.Temas bioéticos

USP/FM/DBD-147/10 
Ao meu avô Ubiratan Ferreira (in memoria), ao Prof. Dr. Dalton de Alencar Fischer Chamone e a minha mãe Erika Severini Ferreira. 


\section{Agradecimentos}


Ao Prof. Dr. Dalton de Alencar Fischer Chamone, meu orientador e minha fonte de inspiração para a realização deste trabalho. Um mestre nato, a quem tenho profundo respeito, admiração e gratidão pelo estimulo, compreensão, ensinamentos, paciência, amizade, confiança e exemplo de dedicação plena à Medicina e aos seus pacientes.

Ao Prof. Dr. Pedro Enrique Dorlhiac-Llacer, uma pessoa ímpar, um profissional impecável e infatigável em desenvolver a excelência da hemoterapia, a quem tenho sincera gratidão pelo apoio, colaboração, amizade, paciência e confiança.

Às Profa. Dra. Giselda Maria Fernandes Hironaka, Dra. Márcia Cristina Zago Novaretti e Dra. Youko Nukui, membros da banca de qualificação, que imprimiram significativo desenvolvimento ao meu conhecimento acadêmico.

À Dra. Aline Maria Monteiro que foi incansável em revisar as partes técnicas do texto, discutir assuntos controversos e ensinar hemoterapia.

À Dra. Geny de Oliveira Barna e ao Dr. César de Almeida Neto que sempre estiveram dispostos a ajudar e muito colaboram enviando textos técnicos.

Ao Dr. Waldemir Washington Rezende, à Dra. Juliana Pereira, ao Prof. Dr. Sérgio Paulo Bydlowski, ao Dr. Élbio D’Amico, à Graciela Brocado, à Gláucia Pancev, à Luciene M. O. Viana, à Terezinha dos Anjos de Oliveira, à Silmara Guerreta, à Elvira Souza e Coelho Benz, à Thânia Rúbia Flores, ao Daniel 
Costa Garcia, ao Antonio A. Turaça Jr., ao Rodrigo Pasqualini, ao Dr. Cyrillo Cavalheiro Filho, à Dra. Juliana Pereira, ao Ernesto Stanguetti e à Adriana Galeazzi pelo incentivo, cooperação e amizade.

À Fernanda Rizzo pela minuciosa e criteriosa revisão ortográfica.

À Débora Levy pela paciência e disposição com que realizou a meticulosa revisão e formatação do texto à normalização obrigatória.

Aos funcionários da Secretária de Pós-Graduação da Faculdade de Medicina da Universidade de São Paulo, especialmente Angélica, Rose Cler e Valéria Vilhena, pela atenção e dedicação dispensada em todos os momentos, durante o curso de pós-graduação.

À minha querida mãe Erika Severini Ferreira; ao meu namorado Frederico Ayroza Cury; à minha avó materna Daici Severini Ferreira (in memória); à minha bisavó materna Maria Villas Boas Severini; à minha irmã Patricia Ferreira Nunes; aos meus amigos Eduardo Frighetto, Renata Barros do Souto e Marcela Albuquerque Rodrigues; aos meus tios Pedro Olavo Severini, Neusa Severini, Marilene Severini Cirilo, Ciro Ubiratan Ferreira, Eliana Severini Ferreira e Paulo Ubiratan Ferreira; à minha família do coração Silvia Elza Kaufmann Chamone, Lourdes Gomes (Vó Hilda), Alcina Gomes pelo afeto e incentivo constantes recebidos para que mais este sonho se tornasse realidade. 
Esta dissertação foi elaborada de acordo com a adaptação International Committee of Medical Journals Editors (Vancouver) e com o Guia de apresentação de dissertações, teses e monografias. Universidade de São Paulo. Faculdade de Medicina. Serviço de Biblioteca e Documentação. Elaborado por Anneliese Carneiro da Cunha, Maria Júlia de A. L. Freddi, Maria F. Crestana, Marinalva de Souza Aragão, Suely Campos Cardoso, Valéria Vilhena. 2a ed. São Paulo: Serviço de Biblioteca e Documentação; 2005.

As abreviaturas dos títulos dos periódicos de acordo com List of Journals Indexed in Index Medicus. 
Sumário 
Lista de abreviaturas e símbolos

Lista de figuras

Lista de quadros

Resumo

Summary

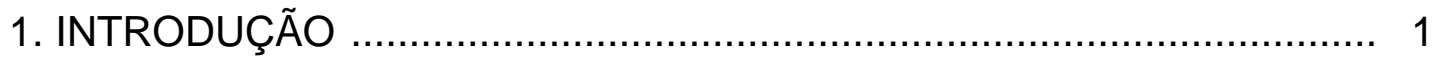

1.1. História da Hemoterapia .......................................................... 3

1.1.1. Da transfusão animal - animal .......................................... 9

1.1.2. Da transfusão animal - homem........................................... 11

1.1.3. Da transfusão homem - homem …………………............. 15

1.1.4. Da descoberta do sistema $A B O$.......................................... 19

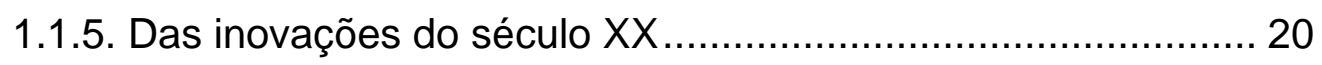

1.1.6. Da descoberta do vírus HIV ............................................... 31

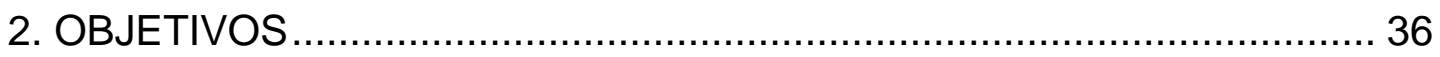

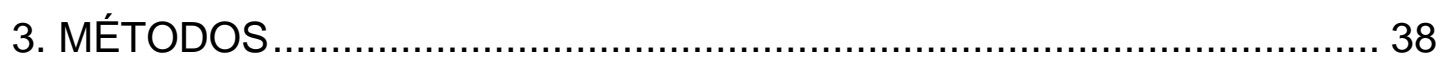

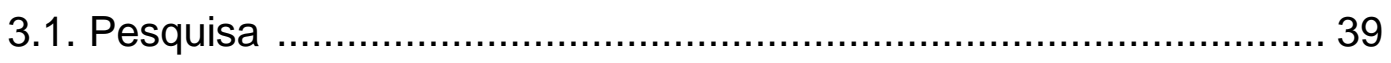

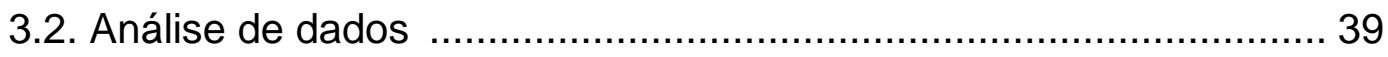




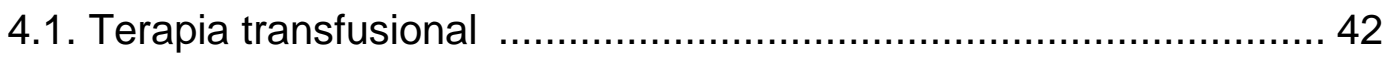

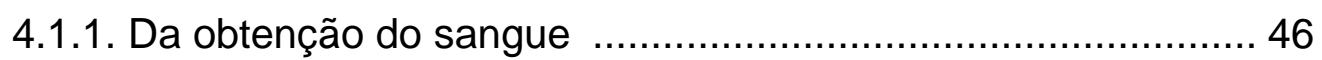

4.1.2. Do cadastro, aferição de sinais vitais, triagem clínica e voto de auto exclusão 48

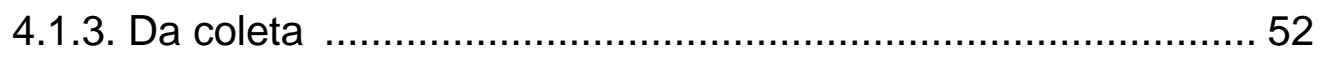

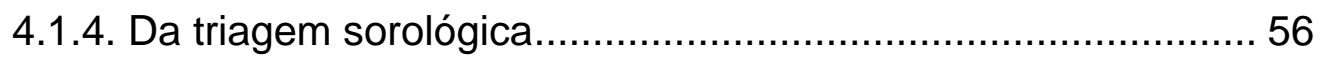

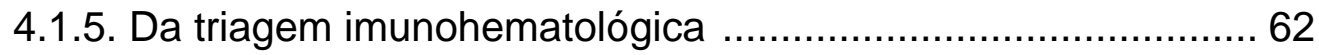

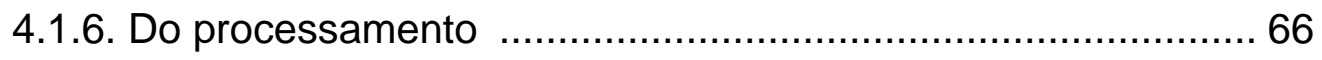

4.1.7. Do manuseio, armazenamento, rotulagem, transporte e procedimentos nos hemocomponentes ............................... 70

4.1.8. Da liberação dos hemocomponentes …………………....... 74

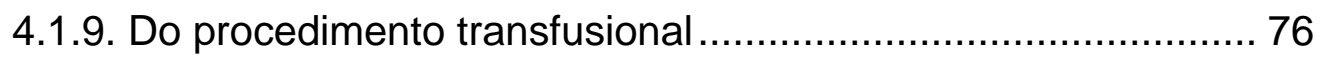

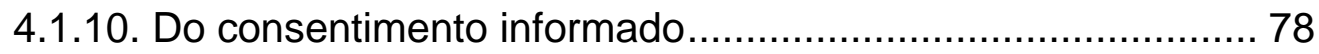

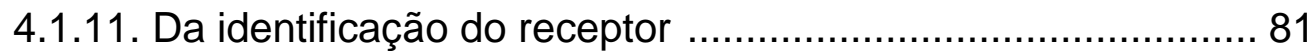

4.1.12. Da solicitação de hemocomponentes ................................ 82

4.1.13. Da coleta de amostra do receptor ....................................... 83

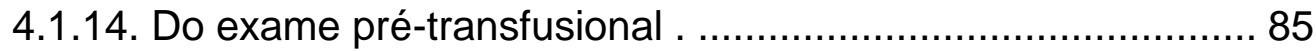


4.1.15. Da liberação do hemocomponente para transfusão

4.1.16. Da infusão do hemocomponente

4.1.17. Das reações transfusionais

5. DISCUSSÃO

5.1. Da Bioética e do Direito 95

5.2. Da compatibilização entre o Direito e a Hemoterapia .98

5.3. Da Regulamentação da Hemoterapia 106

5.4. Da Conceituação da Atividade 108

5.5. Da Previsão Legal acerca da Responsabilidade Transfusional ..... 113

5.6. Das Relações Jurídicas 118

5.6.1. Da Aplicação das Normas vigengentes 124

6. CONCLUSÕES 146

7. REFERÊNCIAS BIBLIOGRÁFICAS 148 
Lista de Abreviaturas e Símbolos 
a.C. Antes de Cristo

AABB Associação Americana dos Bancos de Sangue

ADN Ácido Desoxirribonucléico

AIDS Acquired Immune Deficiency Syndrome ou Síndrome da Imunodeficiência Adquirida

anti-HBc Anticorpos Contra o Core do Vírus da Hepatite B

anti-HCV Anticorpos Contra o Vírus da Hepatite C

anti-HIV Anticorpo do Vírus da Imunodeficiência Humana

ANVISA Agência Nacional de Vigilância Sanitária

art. Artigo

CACTM Comissão de Avaliação e Controle em Medicina Transfusional

Cap. Capítulo

cc Centímetro cúbico

CC Código Civil

CDC Código de Defesa de Consumidor

CF Constituição Federal

CFM Conselho Federal de Medicina

CG Concentrado de Granulócitos

$\mathrm{CH} \quad$ Concentrado de Hemácias

Chap. Chapter ou capítulo

CHBV Concentrado de Hemácias Baixo Volume

CHFIA Concentrado de Hemácias Filtrado, Irradiado e Aliquotado

CHLV Concentrado de Hemácias Filtrado e Lavado

CLT Consolidação das Leis do Trabalho

CMV Citomegalovírus 
CoBi Comitê de Bioética

COFEN Conselho Federal de Enfermagem

CP Concentrado de Plaquetas

CPD Citrato-fosfato-dextrose

CPDA Citrato-fosfato-dextrose-adenina

CRIO Crioprecipitado

d.C. Depois de Cristo

DBS Division of Biologics Standards ou Divisão de Padrôes Biológicos

DNA Ácido Desoxirribonucléico

DST Doença Sexualmente Transmissível

ed. Edição

EIA Teste Elisa

et al. $\quad$ E outros

EUA Estados Unidos da América

FDA Food and Drug Administration

FPS/HSP Fundação Pró-Sangue - Hemocentro de São Paulo

GRID Gay-related Immunodeficiency Disease ou doença da imunodeficiência relacionada a homossexuais

GVHD Reação Enxerto Versus Hospedeiro Relacionada à Transfusão HBV Vírus da Hepatite B

HCFMUSP Hospital das Clínicas da Faculdade de Medicina da Universidade de São Paulo

HCV Vírus da Hepatite C

HIV Vírus da Imunodeficiência Humana 


\begin{tabular}{ll} 
HLA & Antígenos Leucocitários Humanos \\
HTLV & Vírus T-Linfotrópico Humano \\
IFI & Teste Imunoflorescência \\
IgG & Imunoglobulina G \\
IgM & Imunoglobulina M \\
ISBT & International Society of Blood Transfusion ou Sociedade \\
& Internacional de Transfusão de Sangue \\
JAMA & The Journal of the American Medical Association ou Jornal da \\
& Sociedade Médica Americana \\
Kg & Kilograma \\
LAV & Lymphadenopathy-associated Vírus ou Vírus Associado a \\
& Linfoadenopatia \\
ml & Mililitro \\
mI/Kg & Mililitro por kilograma \\
MS & Ministério da Saúde \\
n.o & Número \\
NAT & Teste de Ácido Nucléico \\
PIH & Nacional Institute of Healthy ou Instituto Nacional de Saúde \\
PA & Graus Celsius \\
PCR & Página \\
\hline Pesquisa de Anticorpos Irregulares
\end{tabular}


RDC/MS Resolução de Diretoria Colegiada do Ministério da Saúde

Rh Rhesus

SHOT Serious Hazards of Transfusion ou Risco Sério de Transfusão

SUS Sistema Único de Saúde

TRALI Transfusion Related Acute Lung Injury ou Injúria Pulmonar Aguda Relacionada à Transfusão.

vol. Volume

WB Western Blot 
Lista de Figuras 
Figura 1 - Esquema de processamento da bolsa de sangue total 69 
Lista de Quadros 
Quadro 1 - Determinação de tipagem ABO através da

identificação de aglutinação dos respectivos

reagentes com amostra de sangue do doador

64

Quadro 2 - Determinação do Fenótipo Rh através da

identificação de aglutinação dos respectivos

reagentes com amostra de sangue do doador

65

Quadro 3 - Frequência e percentual de notificações de reações

transfusionais à ANVISA, classificadas por tipo de

reação ocorridas no Brasil em 2007 e 2008

114 


\section{Resumo}


NUNES, HF. Responsabilidade civil e a transfusão de sangue (Dissertação) São Paulo: Faculdade de Medicina, Universidade de São Paulo; 2010. 170p.

O legislador ao normatizar a hemoterapia provocou uma integração da Medicina e do Direito. Com a facilitação do acesso à justiça, inúmeras ações judiciais foram propostas em face das instituições hospitalares e dos profissionais envolvidos nas transfusões de sangue para reparação de prejuízos decorrentes da atividade. De um lado estão os profissionais da saúde, que em alguns casos desconhecem total ou parcialmente suas obrigações, e de outro está o Direito que deve buscar a reparação do dano causado à vitima. Portanto, para que haja o adequado desenvolvimento dos papéis das duas áreas faz-se necessário o apontamento de suas interconexões e conseqüências. Esse trabalho tem por objetivo a análise dos impactos e interfaces da atividade hemoterápica e de suas correspondentes implicações jurídicas ligadas ao instituto da responsabilidade civil previstos no ordenamento jurídico brasileiro vigente. Para realização desse trabalho foram analisadas: a legislação brasileira vigente aplicável ao procedimento de transfusão sangüínea; a literatura médica específica sobre hemoterapia; os estatutos e os códigos de ética dos profissionais da saúde que estão diretamente ligados ao processo da transfusão de sangue; anuários, artigos e manuais de Órgãos de Hemovigilância nacionais e internacionais; e, especificamente, a Padronização para utilização de sangue e hemocomponentes no Hospital das Clínicas da Faculdade de Medicina da Universidade de São Paulo, elaborada pela Comissão de Avaliação e Controle em Medicina Transfusional (CACTM). Muito embora a transfusão de sangue seja uma terapia eficaz, que tem sido amplamente utilizada na medicina moderna, durante ou após sua administração podem ocorrer complicações. A Organização Mundial de Saúde, o Ministério da Saúde e a literatura médica reconhecem os riscos inerentes ao procedimento. $O$ momento mais crítico dessa terapia é a decisão de transfusão de sangue que deve ser baseada em critérios técnicos e nas condições clínicas do paciente, uma vez que será nessa ocasião em que o médico decidirá se irá ou não expor o paciente ao risco. Essa é uma avaliação de riscos que requer conhecimento técnico para embasá-las, como também, para que haja a correta prescrição e administração do hemocomponente que será infundido. O Código Civil Brasileiro prevê que os danos decorrentes de atividades de riscos sejam reparados por meio da responsabilidade objetiva, entretanto, também dispõe que os profissionais liberais que causem prejuízos a terceiros respondam subjetivamente pelo ato danoso. Esse mesmo entendimento está disposto no Código de Defesa do Consumidor, que também se enquadra em algumas situações ligadas à transfusão de sangue. $O$ conhecimento do procedimento transfusional e dos regulamentos pertinentes à atividade nos permite 0 adequado enquadramento do fato à norma, bem como, a conseqüente justa individualização de responsabilidades do processo.

Descritores: 1.Transfusão de sangue 2.Responsabilidade civil 3.Serviço de hemoterapia 4.Temas bioéticos. 
Nunes HF. Civil Responsibility and blood transfusion (dissertation)São Paulo; Faculdade de Medicina, Universidade de São Paulo; 2010. 170p

The standardization of homoterapy under the legislation led to a integration of Medicine and Law. With the ease of access to the judicial system, a lot of lawsuits were filed against hospitals and medicine professionals involved in the blood transfusion process seeking reparation of losses due to the activity. On one side are the medicine professionals that sometimes have a lack of knowledge of their partial or full obligations under the law, and on the other side we have the judicial system and its obligation to seek repair for the patients involved. This work's main objective is to analyze the impacts and interfaces between the homoterapic activity and the legal implications for civil liability under the brazilian law. For this work we analyzed: current brazilian law and regulations applied for the transfusion process; specific blood transfusion literature; statutes, regulations and ethical codes for health professionals who are involved in the process; yearbooks, articles and regulations manuals of haemovigilance organizations; and, especifically the Standardization for the usage of blood and blood products established by "Hospital das Clinicas da Faculdade de Medicina da Universidade de São Paulo" "Comissão de Avaliação e Controle em Medicina Transfusional (CACTM)". Although no one can deny that blood transfusion is a efficient therapy that has been extensively applied in modern medicine, complications may occur during or after the process. The World Health Organization, the Heath Ministry and the medical literature recognize the inherent risks in the process. The most critical moment in blood transfusion therapy is the transfusion decision wich must be based on technical criteria and on the patient clynical conditions, since this is the occasion when the professional will have to make the decision to expose the patient to all the risks involved. This evaluation has to be based on technical knowledge since this knowledge will be needed to prescribe and administrate the blood components. Brazilian Civil Code regulates that damages related to risk activities be repared by objective responsability, however, it also estipulates that area professionals that cause damage to a third party will be legally responsible for their act. The same understanding is also very clear under the consumer defense code wich also mentions the situations involving blood transfusion procedures. The knowledge of the transfusional procedure and the rules related to the activity allows us to establish the guidelines relating to the individual responsabilities of the process. In this case, doctors, nurses and all professionals involved in the transfusion procedure will be eventually responsible for damages only if imprudence, malpractice or negligence is found to be the case. On the other hand, all hemotherapic services, hospitals and any other institutions involved in process will also be liable for damages caused to a third party.

\section{Descriptors: 1.Blood Transfusion 2. Civil Liability 3.Hemoterapy Service}

4.Bioethics Themes 
1. Introducão 
A transfusão de sangue é um procedimento terapêutico "de transferência de sangue ou componente do sangue de um indivíduo (doador autólogo ou heterólogo) para outro (receptor)"1. É considerada uma importante tecnologia moderna de tratamento, que pode ser utilizada para salvar vidas ou melhorar a saúde dos pacientes ${ }^{2}$. Muito embora seja uma terapia eficaz, durante ou após sua administração podem ocorrer complicações agudas ou tardias ${ }^{3-7}$.

Existem incidentes transfusionais em que as complicações são leves e reversíveis, como no caso das reações urticariformes leves, que podem ser solucionadas com medicamento anti-histamínico ou corticóide. Mas, também há aqueles incidentes que podem levar o paciente a óbito, como por exemplo, as reações hemolíticas agudas, a contaminação bacteriana e a contaminação por doenças infecciosas viróticas ${ }^{8}$.

Há que se dizer, que o momento mais relevante dessa terapia é a decisão da realização do ato e indicação do hemocomponente a ser transfundido, que deve ser fundamentada por critérios técnicos já estabelecidos por instituições nacionais e internacionais ${ }^{9,10}$. Isso porque, essa fase é crucial para exposição ou não do paciente ao risco ${ }^{11-12}$.

Portanto, todos os aspectos devem ser considerados antes da tomada de decisão da transfusão de sangue, partindo-se da premissa de que esta é uma terapia efetiva, porém não isenta de riscos ${ }^{13}$.

Deste modo, caso o paciente sofra algum dano iatrogênico ou decorrente de falha humana e/ou de processo oriundo do ato transfusional, as leis nacionais vigentes dispõem de mecanismos que impõem a reparação 
do dano, e serão esses aspectos que serão abordados ao longo deste trabalho.

\title{
1.1 HISTÓRIA DA HEMOTERAPIA
}

\author{
"Un famoso motto latino dice: 'sanguis vita \\ vitae', il sangue è l'essenza della vita"14.
}

A história da hemoterapia é muito curiosa. Entende-se que ela está ligada às guerras, porque é possível mensurarmos os avanços tecnológicos ocorridos durante e posteriormente aos períodos de combate.

$\mathrm{Na}$ antiguidade, há relatos de que o sucesso de uma batalha era evidenciado pelo tamanho do ferimento da tropa. Neste sentido, se as lesões eram mais incapacitantes, elas sangravam mais e os soldados não poderiam defender seu povo ou país do ataque inimigo, o que logicamente era uma conclusão de vitória de uma tropa ou de um exército, porque resultavam na tomada de um local, ou de um bem, ou de um povo.

Esse sangue que se esvaía nas batalhas, despertou a curiosidade dos estudiosos para se entender qual era sua razão funcional, bem como, qual eram os subsídios disponíveis para evitar que o sangramento acentuado resultasse no abatimento dos soldados e, por consequência, na míngua das tropas.

Por outro lado, também é pertinente considerar que as crenças e os mitos da antiguidade colaboraram para o desenvolvimento da ciência. $O$ simbolismo do sangue, seja por sua cor ou fluidez, sempre despertou o 
interesse das pessoas. A evolução dessa curiosidade, as práticas empíricas de cura e os rituais religiosos também culminaram em estudos e experimentos científicos, que deram origem à ciência da transfusão de sangue que hoje conhecemos.

O conceito de vida muitas vezes esteve associado ao sangue, a Bíblia cita a palavra "sangue" mais de 500 vezes sem sugerir que o sangue possuía algum valor para melhorar a saúde ${ }^{15}$. No Livro Levítico 17: 11, por exemplo: "Porque a vida da carne está no sangue; pelo que vo-lo tenho dado sobre o altar, para fazer expiação pelas vossas almas; porquanto é o sangue que faz expiação, em virtude da vida". No Livro Gênesis 9:5, "Certamente requererei o vosso sangue, o sangue das vossas vidas; de todo animal o requererei; como também do homem, sim, da mão do irmão de cada um requererei a vida do homem". Em Mateus 26:28, "Pois isto é o meu sangue, o sangue do pacto, o qual é derramado por muitos para remissão dos pecados".

A mitologia grega com suas lendas sobre Medéa e Górgonas colaborou por instigar a curiosidade sobre esse líquido vermelho que "carregava a vida".

No Egito antigo, por volta de 2500 a.C., os médicos tratavam seus pacientes com sangria. Em uma das tumbas de Memphis, há uma ilustração que retrata uma sangria feita nos pés e no pescoço de um paciente ${ }^{16}$. Os egípcios acreditavam que banhar-se em sangue era um revigorante energético. Eles sabiam que as artérias saiam do coração se direcionavam para todo o corpo ${ }^{17}$. 
Na China, Huang-T, por volta do ano 1000 a.C., escreveu o livro de medicina chamado Nei Ching (Livro do Imperador Amarelo). Nele, Huang-T dizia acreditar que a alma estava no sangue ${ }^{6}$.

Alcmaeon de Croton, pensador grego do ano 500 a.C., ao praticar dissecção animal, observou que veias e artérias são diferentes ${ }^{18}$. Ele também dizia que o sono era produzido pela saída de sangue da superfície do corpo por meio das veias grossas, sendo que o despertar acontecia quando a circulação voltava a todo o $\operatorname{corpo}^{19}$.

Um filósofo grego, que morava na Sicilia, entre os anos 400 e 450 a.C., chamado Empédocles, acreditava que o coração era um órgão sensorial e teorizava que tudo estava ligado a quatro elementos - terra, água, ar e fogo 20 .

Em 400, a.C., Hipócrates, o pai da Medicina, foi o precursor do pensamento científico porque iniciou a explicação racional para justificar a doença e a saúde, por intermédio da teoria dos quatro humores corporais. Segundo essa teoria, a vida era mantida pelo equilíbrio entre os quatro humores: sangue, flegmão (fleuma), biles amarela e biles negra, que proviam os respectivos órgãos: coração, cérebro, fígado e baço. Para ele, as pessoas adoeciam quando houvesse o desequilíbrio de um destes elementos ${ }^{21}$.

O filósofo grego Aristóteles, no ano de 350 a.C., acreditava que o coração era o centro do corpo humano e por esta razão, nele estava assentada a alma dos seres humanos. Baseado em observações, ele dizia que o coração era um órgão de três câmaras, mesmo nos seres humanos ${ }^{16}$. 
Em Alexandria, no ano de 300 a.C., Herophilus de Chalcedon foi um dos primeiros anatomistas gregos a assumir publicamente que dissecava cadáveres. Com isto, ele determinou que as artérias são mais espessas que as veias e que ambas carregam sangue ${ }^{16}$.

Por volta de 270 a.C., Erisitratos, também de Alexandria, foi o primeiro a descrever o coração como uma bomba natural ${ }^{17}$.

Entre 130 e 200 a.C., Claudius Galeno, um dos médicos mais importantes da história, ao realizar experiências e dissecar animais, provou que nas artérias tinha sangue e também sugeriu que os sistemas de veias e artérias são completamente diferentes. Para Galeno, o sangue era formado no fígado e transportado por todo corpo $^{16}$. Ele verificou que o sangue das artérias era fino e claro e o das veias era vermelho-escuro. Acreditava que o sangue arterial era criado a partir da passagem do sangue venoso entre os ventrículos por poros dos septos ${ }^{17}$.

Taurobolium era o nome de um ritual antigo de purificação, praticado pelos romanos, por volta de 160 a.C. Nesse ritual, os romanos acreditavam que as pessoas estariam purificadas após serem banhadas por sangue de touros sacrificados ${ }^{17,22}$.

Aulo Cornelius Celso, médico romano, que viveu entre 14 a.C. a 37 d.C., relatou em sua obra De Medicina: a) os benefícios da sangria terapêutica; b) que borrifar vinagre sobre a superfície do corte ajudava a estancar o sangramento e dissolvia coágulos que estivessem alojados no interior do crânio; c) que a ingestão de sangue quente, recém-saído da garganta de um gladiador, curava epilepsia; e d) que o derrame ocular 
poderia ser tratado com a aplicação de sangue de pomba, pombo-bravo ou andorinha no olho doente ${ }^{23}$.

Em 1242, o médico árabe Ibn al-Nafis descobriu e relatou a circulação pulmonar $^{24}$.

No século XV a ingestão de sangue era recomendada como tratamento para tratamento de doenças psíquicas e para rejuvenescimento, os médicos dessa época não correlacionavam esse tipo de terapia às perdas de sangue ou anemia ${ }^{25}$. Além disso, como remanescia o pensamento hipocrático da teoria dos quatro humores corporais, as sangrias eram comumente prescritas como tratamento de tal desequilíbrio. Por serem considerados procedimentos simples não necessitavam de médicos para sua realização. Essa técnica era usualmente executada por cirurgiões barbeiros $^{26}$.

Alguns historiadores da medicina descrevem que em 1492, o autor romano Stefano Infessura, pela primeira vez relatou uma transfusão de sangue feita entre seres humanos. Na ocasião, um médico sugeriu uma transfusão de sangue de três crianças de dez anos a ser feita no Papa Inocêncio VIII que estava em coma. Para realizar a transfusão foi prometido às três crianças moedas de ouro em quantia equivalente a um título de ducado a cada uma. $O$ procedimento falhou. O Papa e as três crianças morreram $^{27}$. Há outra corrente de historiadores que diz que há algumas versões originárias do século XIX que sugerem que 0 sangue foi transfundido no Papa. Entretanto, mais tarde, evidências mais plausíveis dizem que o sangue foi ingerido pela boca e não transfundido ${ }^{17}$. Muitos autores não acreditam nesse relato e acusaram Infessura de antipapismo. 
Por essa razão, esse caso foi ocultado pela Igreja Católica durante muito tempo ${ }^{28}$.

Há registros históricos que creditam a Hieronymus Cardamus, que viveu entre $1505-1576$, a sugestão da realização da transfusão sanguínea ${ }^{29}$.

O médico e teólogo espanhol Michael Servetus, em 1553, desconhecendo a descoberta de al-Nafis, relatou que o sangue flui de um lado para outro do coração, através dos pulmões, em vez de passar pelas paredes dos ventrículos, contestando a teoria de Galeno. Servetus foi condenado à fogueira por heresia, porque negava a Santíssima Trindade ${ }^{30}$.

Andrea Cesalpino, médico italiano, em 1593, teorizou a circulação do sangue. Ele defendia a ideia de uma circulação química, na qual repetidamente o sangue evaporava e condensava ${ }^{31}$.

$O$ século $X V I$ se encerrou com uma vaga sugestão de que o procedimento transfusional poderia ser administrado na corrente sanguínea do paciente e sem nenhum registro de transfusão eficaz ${ }^{26}$.

Em 1603, um cientista e cirurgião de Pádua, que era fascinado por anatomia, chamado Hieronymus Fabricius, publicou um estudo chamado "As válvulas nas veias", demonstrando a existência de válvulas nas veias, porém não soube explicar corretamente seu uso. O referido estudo continha o primeiro desenho das válvulas das veias ${ }^{28,32,33}$.

Andreas Libavius, médico e químico alemão, em 1615, descreveu como a transfusão de sangue poderia ser feita com um tubo de prata, porém não há registros que demonstram que ele tenha tentado realizar alguma vez o procedimento ${ }^{26}$. 
Em 1628, o médico inglês Willian Harvey, que havia sido orientado por Fabricius em Pádua, publicou sua obra Exercitatio anatomica de motu cordis et sanguinis in animalibus (Tratado de anatomia baseado no movimento do coração e sangue em animais) e foi o pioneiro em descrever corretamente o sistema circulatório. Nesse trabalho, ele explicou o real uso das válvulas descobertas por seu mestre Fabricius e ainda sustentava a ideia de que o sangue era bombeado pelo coração das artérias para as veias, em circuito fechado para o corpo e retornava para o coração ${ }^{32,34}$.

A teoria de Galeno, de que o sangue era formado no fígado e meramente passava pelas veias, artérias e coração, e então seguia para toda a periferia do corpo, permaneceu vigente por 1400 anos até que Harvey descobriu o sistema circulatório ${ }^{17}$.

\subsubsection{DA TRANSFUSÃO ANIMAL-ANIMAL}

Em 1639, Francis Potter inspirado pela tragédia grega Medéa de Ovídio foi o precursor em conceber a transfusão de administração venosa. Ele relatava em correspondências enviadas ao seu amigo John Aubery, que havia criado um aparato com propósito transfusional utilizando penas de gansos (como agulhas) ligadas por tubos. Em 1649, ele escreveu uma carta ao seu amigo dizendo que tentou perfazer a transfusão com o seu aparato em duas galinhas, porém não há registros se ele foi ou não bem-sucedido em sua experiência ${ }^{26}$.

O descobrimento do sistema circulatório por Harvey abriu caminho para o início das experiências de infusão vascular. Em 1642, George Von Wanhrendorff injetou vinho em cães. 
Em 1654, o médico fiorentino Francisco Folli declarou ter sido o inventor da transfusão sanguínea e algum tempo depois descreveu detalhadamente o processo e o aparato que deveria ser utilizado no procedimento $^{26}$.

Em 1656, Christopher Wren e Robert Boyle, ambos da Universidade de Oxford, injetaram ópio e outras drogas também em cães ${ }^{17,28}$.

Em 1658, Jan Swammerdam, um cientista alemão, foi a primeira pessoa a observar em microscópio e descrever as hemácias ${ }^{28,35}$.

Em 1661, Marcelo Malphigi, anatomista italiano, utilizando um microscópio rudimentar observou o sistema capilar vascular ${ }^{18}$.

Na Alemanha, em 1664, Johann Daniel Major realizou a primeira injeção intravenosa e publicou o feito em $1667^{27}$.

Richard Lower era estudante em Oxford quando Wren e Boyle iniciaram seus experimentos de infusão, após a descoberta do sistema circulatório feita por Harvey. Lower associou-se a um grupo de estudantes que estudavam a injeção intravenosa de ópio, eméticos e outras substâncias em animais vivos. Com o tempo, a transfusão de sangue se tornou seu objetivo de pesquisa ${ }^{17}$.

Num destes experimentos, ele inseriu um tubo na veia jugular de um cão e o ligou a veia jugular de outro. $\mathrm{O}$ experimento não deu certo. $\mathrm{O}$ sangue coagulou e entupiu o tubo. Com isso, ele descobriu que veias, ao contrário das artérias, carregam o sangue com baixa pressão, porque levam o sangue de volta ao coração ${ }^{36}$.

Em fevereiro de 1665, o experimento foi bem-sucedido quando Lower ligou a artéria carótida do cão doador à veia jugular do cão receptor. Por 
esse feito, ele recebeu o crédito de perfazer a primeira transfusão entre animais $^{17}$.

Lower foi pioneiro em indicar a transfusão de sangue para perdas agudas ou necessidades de reposição de sangue. Entretanto, ainda remanescia o pensamento sobre o possível benefício emocional e psíquico da transfusão sanguínea ${ }^{37}$.

Para realizar seu experimento, Richard Lower utilizou uma seringa rudimentar desenvolvida pelo arquiteto Christopher Wren, que tinha agulha de pena e bexiga de ganso ${ }^{28}$.

Nesta época, havia uma acentuada disputa entre a França e a Inglaterra para o desenvolvimento de pesquisas científicas. Em 1662, os ingleses fundaram a British Royal Society que realizou vários estudos sobre transfusão sanguínea como o desenvolvido por Richard Lower. Em 1666, com o patrocínio do Rei Luis XIV, a França fundou a Académie des Sciences de Paris. A academia francesa reviu os estudos sobre transfusão feitos pelos ingleses com bastante interesse. Alguns autores dizem que Denis provavelmente leu o artigo de Lower que foi publicado no Journal de Savatus, em 31 de janeiro de 1667. Inspirado em tal documento, um mês depois da referida publicação, iniciou seus experimentos transfusionais ${ }^{17}$.

Em 1667, Claude Tardy, da Faculdade de Medicina de Paris escreveu o primeiro livro sobre utilidade da transfusão de sangue ${ }^{38}$.

\subsubsection{DA TRANSFUSÃO ANIMAL-HOMEM}

Em 15 de junho de 1667, o médico francês do monarca Luis XIV, Jean-Baptist Denis realizou a primeira transfusão de sangue em humanos. 
Ele transfundiu um jovem que apresentava uma febre persistente e estava sonolento. Para tanto, Denis retirou três onças de sangue do menino e injetou nove onças de sangue de cordeiro $^{17,28}$. O procedimento foi bemsucedido. $\mathrm{O}$ jovem se recuperou da letargia e engordou ${ }^{32}$.

Segundo ROSSI, SIMON, MOSS $(1991)^{17}$, o sucesso do procedimento transfusional e a aparente melhora dos sintomas do paciente podem ser explicados pelo diagnóstico de uma profunda anemia. Com a única transfusão houve o aumento do transporte de oxigênio pelo sangue, resultando numa melhora aparente do quadro clínico do paciente.

A segunda transfusão em humanos foi realizada em um homem robusto, que utilizava cadeira de rodas. Ele recebeu sangue de uma ovelha e retornou ao trabalho no dia seguinte aparentando boa saúde ${ }^{32}$.

A terceira transfusão foi feita em um jovem nobre sueco chamado Barão Bonde. Enquanto fazia um grand tour pela Europa, o jovem Barão adoeceu em Paris. Sua saúde estava tão abalada que seus médicos o abandonaram. O Barão Bonde e sua família optaram pela transfusão como último recurso para seu tratamento. A transfusão foi feita com sangue de bezerro. O paciente teve uma rápida melhora e voltou a falar, porém, morreu durante a segunda sessão de transfusão ${ }^{32}$.

Denis e seu assistente Paul Emmerez realizaram a quarta transfusão, em 19 de dezembro de 1667, em um paciente com doença mental com comportamento maníaco-violento ${ }^{39}$, chamado Antoine Mauroy, de 34 anos. Os médicos retiraram dez onças de sangue de Mauroy e injetaram nele, aproximadamente, cinco a seis onças de sangue da artéria femural de um bezerro. Sem reações aparentes, os médicos realizaram uma segunda 
sessão de transfusão em Mauroy, que resultou em uma clássica evidência de reação transfusional aguda (arritmia, suor, dor lombar (rins) e enjoo). Mauroy adormeceu por volta das dez da noite e acordou na manhã seguinte com a urina preta "como se a tivessem misturado com fuligem de chaminé"17.

Dois meses depois da realização dos procedimentos, os sintomas mentais retornaram e Perrini, esposa de Mauroy, procurou Denis para realizar novo tratamento transfusional. Mas este novo procedimento acabou por não ser realizado, pois Mauroy faleceu na manhã seguinte ao da decisão de execução de outra transfusão.

Após o falecimento de Mauroy houve grande comoção entre os médicos de Paris em relação à continuação dos experimentos transfusionais $^{32}$, tendo em vista que eles não sabiam se a morte dele possuía alguma relação com o procedimento executado anteriormente. Por esse motivo, três médicos procuraram Perrini e encorajaram-na a processar Denis por má prática médica. No entanto, ela foi procurar Denis para tentar extorquí-lo, pedindo a ele que pagasse pelo seu silêncio ${ }^{32}$, e em troca ela não ajuizaria uma ação contra ele.

O caso acabou sendo discutido na Corte Francesa de Julgamento. Em 17 de abril de 1668, Denis foi absolvido porque não apuraram qualquer irregularidade no procedimento, e também porque havia provas de que Mauroy faleceu em razão de envenenamento cometido por sua esposa Perrini. No entanto, por causa do incidente, o Parlamento Francês exigiu que todas as transfusões de sangue a serem realizadas, fossem autorizadas pela Faculdade de Medicina de Paris ${ }^{27,32}$. 
Denis utilizava sangue de animais nas transfusões porque acreditava que ele continha menos impurezas (tristezas, inveja, melancolia, inquietação e geralmente todas as paixões que eram causas de muitos problemas nos seres humanos). Para ele, esses sentimentos corrompiam todas as substâncias do sangue ${ }^{32}$, o que era a remanescência do pensamento hipocrático dos quatro humores corporais.

Neste mesmo período, na Inglaterra, o médico Edmund King ofereceu 20 shillings a um indigente chamado Arthur Coga para nele realizar uma transfusão de sangue de ovelha. Em 23 de novembro de 1667, Coga aceitou a oferta com a expectativa de que 0 procedimento lhe trouxesse uma sensação refrescante. A transfusão aconteceu e o paciente recuperou-se bem. Uma semana após a transfusão, Coga foi até a British Royal Society dizer que se sentia um novo homem, muito embora estivesse com alguns ferimentos na cabeça $a^{32}$.

Em 1668, a British Royal Society e o Vaticano também proibiram as transfusões sanguíneas em razão das deliberações do Parlamento Francês, após o caso de Denis. Com essas proibições, a evolução das transfusões de sangue ficou paralisada por 150 anos $^{17,32}$.

Durante o século XVIII, as transfusões foram feitas esporadicamente e geralmente de animais para homens ${ }^{32}$.

Acreditava-se que as transfusões curavam doenças mentais, que rejuvenesciam pessoas, e que o sangue carregava as características do doador para o receptor. Transfusões recíprocas foram sugeridas como solução para discórdia entre casais ${ }^{17}$. 
Em 1771, Willian Hewson, anatomista britânico, em seu livro Experimental enquiry into the properties of the blood, detalhou sua pesquisa em coagulação sanguínea, demonstrando seu sucesso em interromper a coagulação e isolar a substância "coagulable lymph", atualmente conhecida como fibrinogênio. Ele foi o pioneiro em concluir que o timo e o baço produziam os linfócitos. Com base nesta observação, ele concluiu que ambos produzem linfócitos ${ }^{40}$.

\subsubsection{DA TRANSFUSÃO HOMEM-HOMEM}

Em 1795, uma nota de rodapé de uma revista médica creditava a titularidade da realização da primeira transfusão entre humanos ao médico Philip Syng Pysik, embora seu trabalho não tenha sido publicado ${ }^{41}$.

James Blundell formou-se na Universidade de Edimburgo. Logo após a graduação, aceitou um posto de fisiologista e obstetra no Hospital Guy's. Foi neste hospital que ele iniciou seus experimentos com transfusão. As frequentes mortes por hemorragia pós-parto o incomodavam. Isto fez com que, em 1818, ele escrevesse o estudo intitulado: Experiments on the Transfusion of Blood by Syringe. Nesse estudo, ele descreveu com detalhes uma série de experimentos realizados com animais. Ele ainda explicou que: 1) a seringa poderia ser usada na transfusão; 2) que o efeito letal da perda de sangue arterial, poderia ser revertido pela transfusão de sangue venoso ou arterial; 3) que a injeção de 20 cc de ar na veia de um cachorro pequeno não era fatal; e 4) que a transfusão interespécie era fatal para o receptor. Ele foi o pioneiro em dizer claramente que o sangue humano deveria ser utilizado nas transfusões em seres humanos ${ }^{42}$. 
Esta conclusão foi posteriormente confirmada por Dumas e Prevot, que demonstraram que a infusão de sangue heterólogo num animal com hemorragia produzia temporariamente melhoras, mas era seguida de morte em 6 dias $^{32}$.

A primeira transfusão de sangue bem documentada, feita com seres humanos, aconteceu em 26 de setembro de 1818 e foi realizada por Blundell. $O$ paciente tinha 30 anos e era extremamente magro, em razão de uma obstrução pilórica causada por um carcinoma gástrico. Ele recebeu entre 12 a 24 onças de sangue em aproximadamente 30 a 40 minutos. Apesar de uma aparente melhora inicial, o paciente faleceu em dois dias ${ }^{32}$.

Blundell posteriormente transfundiu com sucesso uma mulher com hemorragia pós-parto. Das dez transfusões realizadas por Blundell, cinco foram bem-sucedidas (quatro pacientes com hemorragia pós-parto e um garoto com sangramento por amputação de membro) e cinco foram malsucedidas (três pacientes moribundos, uma mulher com septicemia puerperal e um homem com carcinoma terminal $)^{17}$.

Os artigos de Blundell mostravam que ele era contrário à utilização de sangue animal e acabou por introduzir as indicações racionais de sangue para transfusão. Normalmente ele utilizava sangue doado do marido das pacientes para transfundi-las.

Em 1835, Bischoff propõe a desfibrinação. Brown-Sequard agitava o sangue, acompanhava a formação do coágulo, retirava-o, e depois transfundia o sangue ${ }^{18}$.

Em 1854, Bovel e Hodde, em Toronto, utilizaram leite como substitutivo do sangue durante uma epidemia de cólera. Eles acreditavam 
que o leite se transformava nos corpúsculos brancos do sangue. Para o tratamento utilizavam a injeção de 12 onças de leite na corrente sanguínea dos pacientes. Dois pacientes receberam a injeção de leite e passaram bem, porém outros cinco pacientes receberam as injeções e morreram ${ }^{27,43}$.

Em 1860, Neudofer recomendou o uso de bicarbonato de sódio como anticoagulante ${ }^{5}$

Em 1861, Louis Pasteur demonstrou que a contaminação bacteriana fúngica causava putrefação ${ }^{44}$

Em 1867, o cirurgião inglês Joseph Lister, inspirado nos estudos de Pasteur, introduziu a antissepsia para reduzir as contaminações na realização de cirurgias $^{43}$.

Em 1868, o obstetra $J$ Braxton-Hicks estudou a prevenção de coágulos com a adição de solução de fosfato de sódio enquanto o sangue estava sendo drenado. Uma mulher faleceu após receber o sangue com tal solução ${ }^{45}$

Em 1873, o médico polonês $F$ Gaseleius publicou um estudo demonstrando que $56 \%$ das transfusões realizadas na Polônia resultaram em morte m $^{32}$

Em 1874, Sir Willian Osler observou que pequenos fragmentos celulares de medula formam o centro dos coágulos nos vasos sanguíneos; estes fragmentos foram posteriormente chamados de plaquetas ${ }^{26}$.

Também em 1873, Joseph Howe, de Nova lorque, tentou utilizar o leite de cabra como substituto do sangue nas transfusões. Ele injetou leite de cabra em três pacientes terminais portadores de tuberculose. Um deles faleceu quatro horas após a realização do procedimento, o segundo faleceu 
em vinte quatro horas após o fim da infusão e o terceiro melhorou. Mesmo com resultados negativos, o dr. Howe continuou seus experimentos injetando leite de cabra em cachorros ${ }^{43}$.

Leonard Landois, fisiologista alemão, em 1875, foi pioneiro em estudar a aglutinação. Ele analisou 478 transfusões e verificou que em um terço das transfusões animal-homem os pacientes apresentavam melhoras e em metade das transfusões homem-homem os pacientes apresentavam melhoras. Com essa pesquisa ele demonstrou que os glóbulos vermelhos de um animal, ao serem misturados com o soro de outra espécie, normalmente resultam em aglutinação ou hemólise das hemácias ${ }^{12}$. Esta foi a constatação da eficácia da transfusão homem-homem ${ }^{45}$.

TG Thomas, de Nova lorque, entre 1875 e 1878, também tentou tratar pacientes utilizando leite em vez de sangue nas transfusões. Ele realizou o procedimento em sete pacientes e observou reações durante e pósprocedimento, tais como taquicardia, febre, dor de cabeça etc. Por fim, não houve óbitos ${ }^{46}$.

Em 27 de janeiro de 1879, José Marcondes Filho fez em sua tese de doutoramento o primeiro relato acadêmico sobre hemoterapia no Brasil ${ }^{47}$.

Por volta de 1880, a solução salina intravenosa foi inventada e passou a ser utilizada como expansor do sangue, pois evitava a flebite às vezes sistêmica, bem como, a incompatibilidade imunológica entre as espécies e também entre humanos, uma vez que com a infusão de sangue havia o risco de $35 \%$ de acontecer hemólise ou aglutinação ${ }^{43}$. 
Em 1889, Charrin e Roger reconhecem a aglutinação bacteriana em culturas de Pseudomonas Aeruginosas, incubadas em soro imune de coelho $^{27}$.

Em 1892, Landois sugeriu a utilização de outro anticoagulante o "hiridium" extraído das sanguessugas. Esse produto foi utilizado por Satterlee e Hookes em 1914, mas as dificuldades para obtê-lo puro, a confiança para usá-lo e a estreita variação entre a eficácia e as doses tóxicas da droga tornaram o seu uso perigoso. Os suíços foram os precursores a pensar que o cálcio poderia ser utilizado como anticoagulante e utilizaram pequenas quantidades de sal solúvel como o ácido oxálico para evitar a formação de coágulos no sangue ${ }^{45}$.

Grumber e Durham foram os primeiros a verificar que a reação antígeno-anticorpo fosse provavelmente específica ${ }^{27}$.

\subsubsection{DA DESCOBERTA DO SISTEMA ABO}

Karl Landsteiner era imunologista e pesquisador do Instituto de Anatomia Patológica de Viena, efetuou um estudo para analisar a reação da mistura de amostras de sangue de pessoas sadias com amostra de pessoas doentes. Com essa pesquisa ele verificou que as amostras de sangue de pessoas sadias também aglutinavam ${ }^{17,32}$.

Em 1900, ele publicou um artigo sobre as propriedades químicas do sangue, fluidos linfáticos e plasma, e disse que a aglutinação poderia ser causada por contaminação bacteriana ou diferenças individuais do sangue humano. Dessa forma, ele concluiu: "may assist in the explanation of the various consequences of therapeutical blood transfusions". As ideias de 
Landsteiner demoraram muito para se difundir. Com isto, muitos achavam que ele era muito revolucionário. Suas conclusões tiveram que aguardar mais de trinta anos até serem alçadas pelas ideias de Gregor Mendel com as leis da hereditariedade. Em suas pesquisas ele também concluiu que o sangue coagulava em contato com o $\mathrm{ar}^{32}$.

Em 1901, Landsteiner publicou um documento detalhando a descoberta dos grupos sanguíneos $A, B$ e C, que mais tarde foi denominado O. Para realizar esse trabalho ele utilizou amostras de sangue de várias pessoas e fez várias combinações com plasma e hemácias, tendo observado a aglutinação em algumas amostras e nenhuma formação em outras. Com isto, ele deduziu que existem dois tipos de anticorpos que causam a aglutinação ${ }^{26}$. Somente em 1930, ele recebeu o Prêmio Nobel de Medicina por ter descoberto o grupo sanguíneo ABO humano, apesar de essa descoberta ter sido uma das mais significantes para o exercício da hemoterapia $^{48}$

Em 1902, Landsteiner, Alfred von Decastello e Adriano Sturli identificaram um quarto grupo sanguíneo, o grupo $A B^{26}$.

\subsubsection{DAS INOVAÇÕES DO SÉCULO XX}

Na cidade de Chicago, em 1907, o dr. Ludvig Hektoen recomendava a análise do sangue de doadores e receptores para detecção de sinais de incompatibilidade e escreveu dois artigos para enfatizar e divulgar a descoberta de Landsteiner ${ }^{26,49}$.

No Hospital Mount Sinai em Nova York, o dr. Reuben Ottemberg realizou a primeira transfusão utilizando a prova cruzada. Nos anos 
seguintes, utilizou com sucesso esse procedimento em 128 casos, reduzindo significativamente as reações transfusionais por incompatibilidade $\mathrm{ABO}^{26}$.

Em 1909, George Washington Crile escreveu uma monografia sobre o desenvolvimento de uma cânula com três torneiras de passagem para melhora do fluxo sanguíneo durante o procedimento transfusional. Com isto, a transfusão direta tornou-se possível e popular antes da Primeira Guerra Mundial $^{50}$. Essa nova técnica permitiu que ele realizasse 61 transfusões em 55 pacientes. Essa técnica foi denominada por ele de Carrel $^{32}$. O fator negativo da técnica Carrel era não poder mensurar a quantidade de sangue transfundido ${ }^{51}$.

No fim da primeira década do século XX, em média, 20 transfusões eram realizadas por ano no Hospital Mount Sinai, em Nova York ${ }^{32}$.

Mas mesmo com as novas técnicas, o procedimento continuava a ser doloroso. Então, Crile utilizou anestésicos (morfina e cocaína) para diminuir a penúria do fator físico ${ }^{32}$.

Nesse período, foi evidenciado que a transfusão direta evitava a aglutinação. O primeiro foco de atenção técnica era a manutenção do fluxo sanguíneo. Entretanto, um problema que ainda causava preocupação nos médicos era a quantidade ideal de sangue a ser retirado do doador e infundido no receptor ${ }^{32}$.

As doações eram muito traumáticas neste período, por esta razão era muito difícil encontrar um doador. Em vista disso, para que alguma pessoa doasse o sangue ela recebia US\$ 50 por doação ${ }^{32}$.

Em 1911, Curtis e David inventaram um sistema de transfusão semidireta. Com ela passou a ser possível a mensuração da quantidade de 
sangue transfundida no paciente, o que foi um avanço significante para a medicina hemoterápica da época ${ }^{52}$.

Em 1913, o dr. Edward Lindeman, do Belueve Hospital de Nova York, utilizou uma seringa múltipla para executar as transfusões de sangue, o que eliminou a necessidade de cortar o braço do paciente para a realização do procedimento. Essa nova técnica também permitia a medição da quantidade de sangue transfundida ${ }^{32}$.

Em Bruxelas, Albert Hustin e em Buenos Aires, Luis Agote, no ano de 1914, quase que simultaneamente, descobriram que a adição de citrato de sódio ao sangue depois de coletado evitava a formação de coágulos ${ }^{26}$.

Em 1915, o dr. Richard Lewisohn, do Hospital Mount Sinai em Nova York, formulou a melhor concentração (2\%) de citrato de sódio para ser adicionada ao sangue doado para evitar coagulação, sem causar prejuízos aos receptores. O dr. Richard Weil notou que o sangue citratado poderia ser estocado no refrigerador por vários dias ${ }^{26}$.

Em 1916, no Instituto Rockfeller em Nova York, Francis Peyton Rous e JR. Turner desenvolveram uma solução de sal, isocitrato e dextrose com as finalidades anticoagulante e preservante que permitiam que o sangue fosse estocado durante várias semanas após a coleta e mesmo assim permanecesse viável para ser transfundido ${ }^{26}$.

No Brasil, também em 1916, Isaura Leitão defendeu a tese de doutoramento chamada "Transfusão Sanguínea", na qual descreveu a realização de quatro casos de transfusão. Nesse período, os doadores de sangue no Brasil eram remunerados por 500 réis para cada centímetro cúbico de sangue doado quando fossem doadores não imunizados, já os 
doadores imunizados recebiam 750 réis para cada centímetro cúbico de sangue doado. Os bancos de sangue não aceitavam doadores de emergência, nem voluntários ou altruístas ${ }^{47}$.

Apesar de os médicos utilizarem tubos de borracha para ligar diretamente os doadores e os receptores ou retirar sangue com a seringa no doador e reinjetá-la no receptor, Osvald Hope Robertson, em 1917, criou uma técnica na qual o sangue de um doador previamente selecionado, considerado universal, era retirado por meio de um tudo de borracha e armazenado em recipientes de vidro com a solução citrato-dextrose. Os frascos poderiam ficar acondicionados por até 26 dias no gelo. De tal modo, quando as frentes de batalha precisassem de sangue para transfundir, os frascos poderiam ser transportados para tratar os feridos na guerra. Esse trabalho foi publicado no British Medical Journal em $1918^{36}$.

Em 1922, Percy Lane Oliver iniciou um serviço de doação na sua casa, em Londres. Ele recrutava doadores que concordassem em permanecer à disposição por vinte e quatro horas, para, se necessário, viajarem aos hospitais para doar sangue. Esses doadores eram previamente testados para verificar suas tipagens sanguíneas e a escolha de cada doador dependia do tipo sanguíneo necessário ao receptor. Oliver fez uma relação com nome e telefone dos doadores inscritos, foi o primeiro banco de dados de doadores de sangue ${ }^{30}$.

Em 1923, Arnault Tzanc um dos fundadores da Sociedade Internacional de Transfusão Sanguínea, com a colaboração de Gosset e Levy-Solal organizou o primeiro centro de transfusão no Hospital Saint Antoine, chamado L'Óeuvre Sanguine d'Urgence ${ }^{32,36}$. 
Em meados dos anos 20, o Hospital John Hopkins, em Baltimore (EUA), utilizava sangue desfibrinado nas transfusões ali realizadas. Para tanto, coletava-se o sangue em um Erlenmeyer de vidro, que continha lâminas de vidro. Nesse sistema, o sangue era batido até formar coágulos e estes eram retirados por meio de filtração do sangue em uma gaze. Em seguida, o produto restante filtrado era administrado na veia do paciente. As reações febris eram muito frequentes nos pacientes transfundidos, em razão dos pirógenos presentes nos tubos, gazes, agulhas etc. Alguns hemoterapeutas da época achavam que as reações febris ocorriam em função dos possíveis danos ocorridos às hemácias por causa das batidas para a formação de coágulos ${ }^{53}$.

Em 1923, Seibert descobriu que as substâncias que ocasionavam reações febris eram derivadas do crescimento de bactérias ${ }^{54}$.

Com atraso de alguns anos, em 1928, Cruchet, Ragot e Caussionos escreveram uma monografia contra a transfusão animal-homem ${ }^{52}$.

O dr. Serge Yudin, do Instituto Sklifosovsky, em 30 de março de 1930, foi pioneiro em testar a eficácia da transfusão de sangue de cadáveres humanos. Ele obteve êxito em transfundir um jovem que tentou suicidar-se, cortando seus dois pulsos. Para salvar a vida do jovem, ele infundiu 420 cc de sangue de um cadáver de um homem de 60 anos, que morreu após ser atropelado por um ônibus. Os russos também foram precursores em criar uma rede de instalações para coleta e estocagem do sangue para transfusões em diferentes hospitais de Leningrado ${ }^{36}$.

Em 1935, um grupo de anestesistas da Mayo Clinic, em Rochester, que havia organizado um serviço transfusional dois anos antes, foi o primeiro 
a armazenar o sangue com citrato para ser distribuído aos hospitais dos Estados Unidos ${ }^{36}$

Federico Duran-Jordan, médico, criou, em 1936, o Serviço de Medicina Transfusional de Barcelona, na Espanha. Esse serviço coletava o sangue, testava a tipagem $\mathrm{ABO}$, separava os frascos doados pelos grupos sanguíneos, e os preestocava sob refrigeração. Durante a guerra civil espanhola, o sangue era transportado para os hospitais das frentes de batalha em veículos refrigerados ${ }^{36}$.

Também em 1936, o americano Jonh Elliot e a Baxter Corporation criaram o dispositivo de vácuo para o primeiro frasco de vidro comercial, que veio a substituir as embalagens de leite (vidro) utilizadas até então para o armazenamento de sangue ${ }^{55}$.

Em 1937, o médico Bernard Fantus, diretor de Terapêutica do Hospital Cook Count, em Chicago, criou o termo "banco de sangue" para descrever o local onde o sangue era coletado, testado e armazenado ${ }^{36}$.

Philip Levine e RE Stetson descobriram, em 1939, um anticorpo que até então era desconhecido no sangue da mulher que havia dado à luz um natimorto. Eles acreditavam que um fator presente no sangue do pai, desencadeara uma reação orgânica que produzira anticorpo na mãe ${ }^{36}$.

Com base nas observações feitas por Levine e Stetson, Landsteiner e Alexander Wiener, em 1940, iniciaram uma série de experimentos com glóbulos vermelhos de macacos Rhesus e, com isto, identificaram o anticorpo encontrado no ano anterior, como anti-Rh em referência às iniciais da espécie de macacos utilizados na pesquisa ${ }^{17,32,36}$. Assim como a tipagem ABO descoberta por Landsteiner em 1901, o conhecimento desse novo 
anticorpo foi expressivamente significante para determinar a compatibilidade sanguínea entre o doador e o receptor, o que consequentemente reduziu os óbitos ocasionados por reações transfusionais agudas por incompatibilidade sanguínea ${ }^{32}$.

Entre 1930 e 1940, os Estados Unidos utilizou a placenta para fazer gamaglobulina. Bolonal et al. notaram quatro fortes reações em pacientes que receberam hemoderivados originários de placenta ${ }^{56}$.

No ano de 1940, o dr. Charles Drew, que trabalhava no laboratório central do Hospital Presbiteriano de Nova York, criou um método de separação e preservação do plasma, utilizando modernos aparelhos estéreis. Por esse método ele processava, testava e armazenava o plasma que era coletado nos EUA e transportado para o exterior, por intermédio da Cruz Vermelha ${ }^{36}$

Em Harvard, Edward Cohn, um bioquímico norte-americano, ao buscar um substituto durável para o plasma, criou um método para o fracionamento do plasma, no qual suas diferentes proteínas eram separadas. Numa série de etapas que são repetidas com pequenas variações de temperatura e condições químicas, o plasma era misturado a um solvente (álcool etílico) e centrifugado. Por esse método, denominado fracionamento, eram separados os componentes plasmáticos: fibrinogênio (Fração I), gamaglobulina (Fração II e III) e albumina (Fração V) ${ }^{36}$.

Atendendo a um pedido do Cirurgião Geral das Forças Armadas Norte-Americana, a Cruz Vermelha Norte-Americana, em janeiro de 1941, organizou um serviço de coleta de sangue para suprir as necessidades da guerra. O primeiro centro coletor foi inaugurado em Nova York em 4 de 
fevereiro de 1941 e coletou 13 milhões de unidades durante o curso da guerra. Na Filadélfia, o médico Ididor Ravdin, foi bem-sucedido ao tratar vítimas do ataque a Pearl Harbor com albumina como expansor de volume sanguíneo ${ }^{36}$.

No Brasil, em 7 de dezembro de 1942, foi fundado na cidade do Rio de Janeiro o primeiro banco de sangue, chamado Instituto Fernandes Figueira $^{47}$.

Em 1943, Paul Bresson relatou com detalhes o JAMA (The Journal of the American Medical Association) a ocorrência de sete casos de icterícia, após a transfusão de sangue e plasma em pacientes previamente transfundidos ${ }^{32}$.

Neste mesmo ano, JF Loutit, PL Mollison, I Maureen Young e EJ Lucas publicaram um artigo recomendando a utilização do ACD (acidocitrato-dextrose) como preservante do sangue coletado ${ }^{57}$. O exército americano adotou essa solução em $1945^{32}$ e começou a utilizá-la como preservante dos frascos de sangue.

Ainda em 1945 ocorreram os primeiros relatos brasileiros de transmissão da Doença de Chagas por intermédio da transfusão de sangue ${ }^{29}$.

Em 1947, os bancos de sangue americanos se uniram para formar uma rede nacional, chamada Associação Americana de Bancos de Sangue (AABB). A primeira reunião da AABB aconteceu em novembro de 1947, em Dallas $^{36}$.

Outra revolução ocorrida na coleta de sangue aconteceu em 1948, quando o cirurgião Carl W. Walter revolucionou a coleta de sangue. Ele 
desenvolveu uma bolsa plástica para armazenar o sangue. Até esse período, garrafas de vidro eram utilizadas para estocar o sangue, o que colaborava para a contaminação e proliferação bacteriana nos hemocomponentes, em razão da inadequada antissepsia dos frascos. Além do problema de contaminação, havia ainda a possibilidade desses frascos de vidro se quebrarem ao serem manuseados, o que poderia ferir as pessoas que os manipulassem. A utilização da bolsa plástica também foi importante para o fracionamento dos componentes sanguíneos ${ }^{36}$.

Em 1949, a Cruz Vermelha Norte-Americana começou a utilizar bolsas plásticas para coletar e armazenar o sangue em substituição às garrafas de vidro ${ }^{32}$.

No Brasil, nos anos 50, foi promulgada a Lei $\mathrm{n}^{\circ} 1.075 / 50$ para incentivar a doação de sangue ${ }^{58}$. Ainda no mesmo ano foi realizado o primeiro Congresso da Sociedade Brasileira de Hematologia e Hemoterapia ${ }^{47}$.

Em 1957, foram introduzidas as bolsas plásticas com a mistura CPD (citrato-fosfato-dextrose) utilizada como anticoagulante para evitar a formação de grumos e aumentar a validade dos hemocomponentes ${ }^{32}$.

Em 1959, com o uso da cristalografia de raios X (técnica que revela a distribuição dos átomos), Max Perutz, da Universidade de Cambridge, revelou a estrutura da hemoglobina, que é a proteína dos glóbulos vermelhos que carregam o oxigênio ${ }^{36}$.

Em meados de 1960, Keneth Brinkhous, da Universidade da Carolina do Norte e Edward Shanbrom, dos Laboratórios Hylland, desenvolveram uma técnica para produzir concentrado de fator VIII, a partir do uso de 
concentrado de plasma, que após ser congelado gerava uma grande quantidade de crioprecipitado. Esse crioprecipitado era novamente dissolvido, tratado, filtrado e centrifugado. O resultado desse processo foi a criação de um pó coagulante, cem vezes mais potente que o plasma fresco, que poderia ser facilmente estocado e armazenado por longos períodos ${ }^{36}$.

No Brasil, em 1965, o Ministério da Saúde criou a Comissão Nacional de Hemoterapia e estabeleceu a Política Nacional de Sangue ${ }^{59}$.

Em 1965, a dra. Judith Pool, fisiologista norte-americana da Universidade de Stanford, descobriu que o plasma fresco descongelado lentamente era um depósito rico em fator VIII. Com isso, ela demonstrou que o depósito, chamado de crioprecipitado (crio) é rico em fatores de coagulação. Neste período, iniciou-se o uso de crioprecipitado em pacientes hemofílicos ${ }^{36}$.

Pela primeira vez, em 1968, a Portaria nํ 1, de 24 de maio de 1968 da Comissão Nacional de Hemoterapia Brasileira, conceituou o processo atualmente denominado "ciclo do sangue", porém não especificou quais testes laboratoriais deveriam ser realizados no sangue doado ${ }^{60}$.

Em 1969, a Portaria nํ 4, de 25 de setembro de 1969 da Comissão Nacional de Hemoterapia Brasileira, estabeleceu as condições de rejeição temporária e definitiva para a seleção de doador, e tornou obrigatória a realização dos testes de triagem sorológica no sangue doado para transfusão a ser realizada em pacientes com Doença de Chagas e Sífilis $(\text { Lues) })^{61}$.

Ainda em 1969, Pierre Cazal, em nome da Organização Mundial de Saúde, veio ao Brasil para inspecionar as condições hemoterápicas do país 
e, de posse desses e de outros dados, elaborou um relatório que revelava a situação desastrosa do sistema hemoterápico no mundo em relação a doações remuneradas e sem critério, comercialização do plasma para exportação, doador inaptos sem assistência, sorologia precária, transfusões sem critérios médicos, predominância de utilização de sangue total, falta de coordenação e carência de recursos humanos ${ }^{29}$.

Em julho de 1971, o Secretário de Saúde, Educação e Bem-Estar dos Estados Unidos, Elliot Richardson, transferiu a responsabilidade da gestão da indústria dos bancos de sangue da Division of Biologics Standards (DBS) para Food and Drug Administration (FDA) ${ }^{35}$.

No mesmo ano, o dr. Baruch Blumberg, do Instituto Nacional de Saúde dos Estados Unidos (NIH), identificou uma substância na superfície do vírus da hepatite $\mathrm{B}$, que desencadeia a reprodução de anticorpos. Este trabalho originou o desenvolvimento do teste para detecção de anticorpos da Hepatite B em doadores contaminados. O FDA passou a exigir a realização do teste em todo o sangue doado 35,40

Em 1975, a Organização Mundial de Saúde em assembléia realizada na cidade suíça de Geneva determinou ser responsabilidade dos países a assegurar e prover sangue a todos os pacientes que necessitarem de transfusão, como também, estabelecer planos e políticas públicas voltadas ao uso e produção do sangue ${ }^{62}$.

Em 1977, foi promulgada a Lei $n^{0} 6.437 / 77$, que prevê as ações que são passíveis de configuração de infração sanitária e suas respectivas sanções ${ }^{63}$. 
Em 1979, iniciou-se o uso de CPDA (citrato-fosfato-dextrose-adenina) como anticoagulante preservante nas bolsas plásticas para armazenamento de coleta de sangue ${ }^{64}$, com isto o sangue armazenado passou a ter validade de 35 (trinta e cinco) dias.

Em 30 de abril de 1980, o Ministério da Saúde em conjunto com o Ministério da Previdência Social, expediram uma Portaria Interministerial MS/MPAS no 7 que instituía o Programa Nacional de Sangue e Hemoderivados - PRÓ-SANGUE, baseado no modelo francês para área assistencial de sangue, calcado no conhecido relatório de Pierre Cazal. Os apontamentos feitos por Cazal no relatório foram identificados no país, e o governo brasileiro decidiu assumir a responsabilidade da manutenção do sistema de hemoterapia, garantindo a segurança, qualidade e a universalização do serviço ${ }^{65}$.

\subsubsection{DA DESCOBERTA DO VÍRUS HIV}

Os primeiros casos de uma síndrome inicialmente chamada GayRelated Immunodeficiency Disease (GRID) foram descobertos em 1981, devido a sua prevalência em homens homossexuais. Mais tarde, essa doença foi denominada Acquired Immune Deficiency Syndrome ou Síndrome da Imunodeficiência Adquirida (AIDS) ${ }^{17,32,36}$.

Quando os hemofílicos começaram a desenvolver a GRID, em 1982, o dr. Bruce Evatt, especialista em hemofilia do Centro de Controle e Prevenção de Doenças Norte-Americano, passou a suspeitar que a síndrome pudesse estar relacionada ao sangue que era transfundido nos 
pacientes. Ele apresentou oficialmente essa teoria em julho de 1982, em uma reunião do Nacional Institute of Health $(\mathrm{NIH})^{36}$.

Em 1983, o dr. Luc Montagnier, do laboratório do Instituto Pasteur na França, isolou o vírus que causa a AIDS. Nesse estudo, ele localizou o vírus em um linfonodo aumentado no pescoço de um paciente e o denominou LAV (lymphadenopathy-associated virus) $^{36}$.

Numa conferência realizada em 23 de abril de 1984, o dr. Robert Gallo, do Nacional Institute of Health (NIH), anunciou que o vírus HTLV III (human T-cell lymphotropic virus) causava a AIDS ${ }^{36}$.

Para evitar a propagação da doença que havia contaminado dezenas de americanos por transfusão de sangue, em 2 de março de 1985, foi criado e licenciado o primeiro teste para detecção da presença ou ausência de anticorpos HIV (teste de ELISA). Contudo, o teste foi incorporado a todos os bancos de sangue americanos ${ }^{36}, 66$.

O Estado de São Paulo foi pioneiro em exigir a realização do teste sorológico para HIV no país, por essa razão, em 20 de junho de 1986 promulgou a Lei Estadual n 5.190/86, que tornava obrigatória a realização de prova sorológica individual para HIV ${ }^{67}$.

A partir de então, iniciou-se uma batalha judicial pela titularidade da descoberta do vírus da AIDS, que finalmente se encerrou em 1987, quando os governos americano e francês concordaram em dividir a titularidade da descoberta, como também, os royalties da venda dos "kits" para teste do vírus $^{36}$

Em 1987, o governo brasileiro publicou a Portaria Interministerial MPAS/MS nํ 14/87, que tornou obrigatória a realização de prova sorológica 
para HIV em todo sangue doado para fins transfusionais ou para produção de hemoderivados ${ }^{68}$.

Em 1988, o governo brasileiro promulgou a Lei $n^{\circ}$ 7.649/88, que previa a obrigatoriedade da realização de cadastro dos doadores, além da realização de testagem sorológica para HIV em amostra única, Sífilis, Doença de Chagas, Hepatite $\mathrm{B}$ e, em regiões endêmicas, a prova para Malária. Essa lei também dispôs que a não observância dos critérios nela previstos ensejaria no enquadramento do crime de infração de medida sanitária preventiva prevista no art. 268 do Código Penal ${ }^{69}$.

No ano seguinte, em 1989, o governo brasileiro, por intermédio da Portaria MS no 721/89, normatizou o "ciclo do sangue"70.

Nesse mesmo período, com a evolução das contaminações pelo vírus HIV, inúmeras ações foram ajuizadas contra os fracionadores de plasma e contra os serviços de saúde públicos que indicavam ou prescreviam a infusão de fatores de coagulação causadores das contaminações nos pacientes hemofílicos ${ }^{71}$. Após o julgamento de Jean Baptist Denis, estas passaram a ser as novas disputas judiciais que envolviam o procedimento transfusional. Apesar de muitos especialistas, como o dr. Don Francis e o dr. Edwin Cohen, defenderem a realização de exames nos produtos obtidos por meio do sangue, a indústria insistiu em não efetuá-los, contaminando com o vírus HIV, somente nos Estados Unidos, ao menos 12 mil hemofílicos e 10 mil pacientes. Infelizmente, muitos julgamentos foram favoráveis à indústria e aos serviços de saúde que forneceram o fator de coagulação contaminado ${ }^{32}$. 
Um dos julgamentos mais famosos do período, ocorrido novamente perante a Corte de Justiça Francesa, em 1992, no qual Jean Perón Garvanoff, irmão de dois pacientes hemofílicos e contaminados pelo vírus HIV, ajuizou uma ação contra Michel Garreta e Jean Pierre Allain, da empresa CNTS; Roux, diretor geral de Saúde da França e Robert Netter, diretor do Laboratório Público Nacional de Saúde. Todos foram condenados em última instância pela contaminação dos pacientes, em razão de saberem que o material não fora tratado e, mesmo assim, não evitaram a sua distribuição, sob alegação de que o descarte dos referidos produtos traria muito prejuízo à empresa. Como havia uma grande pressão da indústria farmacêutica na ocasião, o jornal médico Lancet publicou um editorial, assinado por 37 cientistas, relatando a negligência da produção de fatores de coagulação, que ocasionou a contaminação de tantos pacientes ${ }^{32}$. Cabe dizer que, apesar de não ter sido mencionado na decisão, outro fato que concorria para a temeridade da continuidade da distribuição dos fatores de coagulação não tratados era a utilização de sangue coletado de pessoas encarceradas (presidiários) na produção, sendo que já eram sabidos os riscos inerentes a estas populações ${ }^{32}$.

Em 1992, o governo do Estado de São Paulo novamente foi pioneiro na inserção de novo teste sorológico. Desta vez, por meio da Portaria CVS no 1, de 30 de junho de 1992, tornou-se obrigatória no Estado a realização de prova sorológica individualizada para Hepatite $\mathrm{C}$ em todo sangue doado para fins transfusionais e industriais ${ }^{72}$.

Em 1993, a Coordenadoria de Sangue e Hemoderivados do Ministério da Saúde, sob a Chefia do Professor-doutor Dalton de Alencar Fischer 
Chamone, elaborou e publicou a Portaria MS nำ 1.376/93, que tornou obrigatória a realização de provas sorológicas para HIV, Hepatite B, Hepatite C, HTLV I, HTLV II, Doença de Chagas, Sífilis, Malárias (em regiões endêmicas) e dosagem de $\mathrm{ALT}^{29,73}$.

Em 2002, o Ministério da Saúde publicou a Portaria MS n.ำ 262/02, de 05 de fevereiro de 2002 tornando obrigatória a realização pelos serviços de hemoterapia do país dos testes de amplificação e detecção de ácidos nucléicos (NAT), para HIV e HCV, em todas as amostras de sangue de doado para fins transfusionais. ${ }^{74}$. Essa norma acabou revogada pela Portaria MS nำ1.407, de 01/08/2002 ${ }^{75}$, que também foi revogada pela Portaria MS n. ${ }^{\circ} 79$, de 31 de janeiro de $2003^{76}$, que também foi revogada pela Portaria MS n..$^{112}$, de 29 de janeiro de $2004^{77}$. A imposição legal para a realização do teste continua vigente, no entanto até esse momento somente alguns serviços de hemoterapia privados realizam esses testes em suas rotinas de provas sorológicas.

Os desafios futuros da hemoterapia parecem estar direcionados ao aprimoramento da produção do sangue artificial $^{77}$ e de substitutos do sangue, ao aperfeiçoamento das técnicas de testagem sorológica, a detecção de novas patologias transmissíveis pelo sangue, a mecanização dos processos de produção, a melhora das condições de seleção dos doadores, a implementação de políticas, estratégias e processos que garantam a viabilidade, a acessibilidade, a segurança e a qualidade do sangue $^{78}$, etc. Sem dúvida, haverá ainda muita história a ser contada ${ }^{34}$. 
2. Objetivos 
O objetivo do presente trabalho é a análise dos impactos e interfaces da atividade hemoterápica e de suas correspondentes implicações jurídicas ligadas ao instituto da responsabilidade civil previstos no ordenamento jurídico brasileiro vigente. 
3. Métodos 


\subsection{PESQUISA}

Para realização desse trabalho serão analisadas: a legislação brasileira vigente aplicável ao procedimento de transfusão sanguínea; a doutrina médica específica sobre hemoterapia; os estatutos e os códigos de ética dos profissionais da saúde que estão diretamente ligados à cadeia da transfusão de sangue (Conselho Federal de Medicina - CFM, Conselho Federal de Enfermagem COFEN etc.); anuários, artigos e manuais do Órgão de Hemovigilância nacional e internacional; e, especificamente, a padronização para utilização de sangue e hemocomponentes no Hospital das Clínicas da Faculdade de Medicina da Universidade de São Paulo, elaborada pela Comissão de Avaliação e Controle em Medicina Transfusional (CACTM).

A princípio será feita uma breve descrição do procedimento transfusional, desde a coleta até a infusão dos hemocomponentes, com a evidenciação dos pontos críticos de cada etapa do processo, seguida de uma compilação dos princípios hemoterápicos que indicam a conduta da transfusão de sangue e quais as práticas que devem ser adotadas.

Com a descrição criteriosa do panorama da cadeia transfusional, estas informações serão inter-relacionadas à legislação civil brasileira vigente voltada à previsão do instituto jurídico "responsabilidade civil".

\subsection{ANÁLISE DE DADOS}

Os dados obtidos por intermédio do levantamento teórico da doutrina hemoterápica, dos pontos críticos da rotina do procedimento transfusional, dos padrões operacionais técnicos estabelecidos pelos Sistemas de Hemovigilância e das legislações vigentes serão analisados considerando-se cada etapa da 
transfusão de sangue e quem são os profissionais envolvidos em cada fase do processo que permitiram o desenvolvimento lógico de interpretação das informações. 
4. Resultado 


\subsection{TERAPIA TRANSFUSIONAL}

"A terapêutica transfusional com componentes do sangue refere-se à transfusão da parte específica do sangue que o paciente necessita opondose ao uso do sangue total. Esta atitude não apenas conserva os estoques, uma vez que cada unidade doada pode beneficiar diversos pacientes, mas também permite que sejam transfundidas grandes quantidades de um determinado componente que o paciente necessite"79.

O procedimento hemoterápico é previsto em regramento próprio emanado do Ministério da Saúde. Essa norma é Resolução de Diretoria Colegiada do Ministério da Saúde RDC/MS nำ 153/04 que dispõe o "Regulamento Técnico para os procedimentos hemoterápicos, incluindo a coleta, o processamento, a testagem, o armazenamento, o transporte, o controle de qualidade e o uso humano de sangue, e seus componentes obtidos do sangue venoso, do cordão umbilical, da placenta e da medula óssea”.

A atividade hemoterápica é realizada por serviços de hemoterapia. A Resolução RDC/MS no 151/01 vigente classificou os serviços de hemoterapia em categorias determinadas de acordo com o nível de complexidade das atividades executadas por cada instituição. Para tanto, eles foram subdivididos em: Hemocentro Coordenador, Hemocentro Regional, Núcleo de Hemoterapia, Unidade de Coleta e Transfusão, Unidade de Coleta, Central de Triagem Laboratorial de Doadores e Agência Transfusional.

O Hemocentro Coordenador é uma entidade pública, situada preferencialmente na capital dos Estados e deve possuir reconhecimento 
técnico na área de Hemoterapia e/ou Hematologia. Tem por objetivo a prestação de serviço hemoterápico à rede de saúde e deve realizar ensino e pesquisa, formar mão de obra capacitada, realizar controle de qualidade, prestar suporte técnico e apoiar a Secretaria de Estado da Saúde na elaboração de políticas públicas voltadas à atividade hemoterápica. Poderá atuar como distribuidor de hemocomponentes para outros serviços.

O Hemocentro Regional é uma entidade pública, de atuação macrorregional hematológica ou hemoterápica e será responsável por coordenar e executar as ações da política de sangue do Estado voltadas à uma macrorregião de saúde. Poderá encaminhar suas amostras de sangue doado para triagem sorológica para doenças infecciosas a uma Central de Triagem Laboratorial de Doadores e atuar como distribuidor de hemocomponentes para outros serviços.

O Núcleo de Hemoterapia poderá ser uma entidade pública ou privada com atuação hematológica ou hemoterápica microrregional que deverá desenvolver a política Estadual de Sangue. Poderá encaminhar suas amostras de sangue doado para triagem sorológica de doenças infecciosas a uma Central de Triagem Laboratorial de Doadores e atuar como distribuidor de hemocomponentes para outros serviços.

A Unidade de Coleta e Transfusão poderá ser uma entidade pública ou privada, com atuação hematológica ou hemoterápica local que coletará sangue total dos doadores e realizará a transfusão. Pode ou não realizar o processamento do sangue total doado e a triagem imunohematológica dos doadores. Deve encaminhar suas amostras de sangue doado para triagem sorológica para detecção de doenças infecciosas a um Serviço de 
Hemoterapia considerado referência. Poderá atuar como distribuidor de hemocomponentes para outros serviços. Está localizada em um hospital ou em pequenos municípios.

A Unidade de Coleta poderá ser uma entidade pública ou privada com atuação hematológica ou hemoterápica local que coleta sangue total dos doadores, poderá ser móvel ou fixa. Caso seja móvel deverá ser de natureza pública e, caso seja fixa, pode ser de natureza pública ou privada. Ela encaminhará o sangue total coletado a um Serviço de Hemoterapia de referência para a realização do processamento do sangue, da triagem imunohematológica e da triagem sorológica para detecção de doenças infecciosas do sangue doado.

A Central de Triagem Laboratorial de Doadores poderá ser uma entidade pública ou privada local, regional ou estadual, integrante ou não da estrutura de Hemocentros ou Núcleos de Hemoterapia. Será responsável pela realização da triagem sorológica para detecção de doenças infecciosas do sangue doado na própria instituição ou em outros serviços de hemoterapia.

A Agência Transfusional deverá estar localizada preferencialmente em instituições hospitalares e terá como escopo de atuação a armazenagem de hemocomponentes, a realização de exames pré-transfusionais e poderá realizar transfusões dos hemocomponentes liberados para uso. Todo suprimento de sangue a essas entidades deverá ser feito por serviços de hemoterapia de maior complexidade.

A coordenação das atividades hemoterápicas realizadas nos serviços de hemoterapia é feita em âmbito nacional pela Gerência Geral de Sangue, 
Outros Tecidos e Órgãos da Agência Nacional de Vigilância Sanitária do Ministério da Saúde e nos Estados e Distrito Federal pelo gestor local do Sistema Único de Saúde, que são as Secretarias Estaduais de Saúde.

Todo relação de distribuição de sangue e hemocomponentes entre Serviços de Hemoterapia ou Instituições Hospitalares que não possuam Serviço de Hemoterapia deve ser celebrada mediante contrato ou convênio específico para este fim, da mesma maneira que a realização de serviços de triagem sorologica para detecção de doenças infecciosas.

Em caso de emergência o Serviço de Hemoterapia poderá fornecer hemocomponentes sem a devida celebração de um contrato ou convênio desde que: 1. o pedido de solicitação de hemocomponentes assinado e carimbado pelo médico assistente seja encaminhado juntamente com a amostra do sangue do receptor para a realização dos testes prétransfusionais; 2. o pedido seja feito em papel timbrado da entidade solicitante que contenha nome, endereço, número de telefone e fax, e o setor onde será realizada a transfusão; 4. contenha o número do prontuário do paciente, o seu nome completo e idade; contenha quantidade e nome do hemocomponente, com indicação de uso. Sendo que no parágrafo único do art. 8 da $\operatorname{RDC~} n^{\circ}$ 151/01, a instituição solicitante está obrigada a devolver em até 48 horas as bolsas utilizadas ou não à instituição fornecedora, mediante a apresentação de documentos que justifiquem ou comprovem a utilização ou não dos hemocomponentes solicitados.

Os serviços de hemoterapia supramencioandos são ainda classificados anualmente pela Vigilância Sanitária em quatro níveis definidos de acordo com a gama de atividades que executam. 
Pertencem ao nível um ou dois os Hemocentros Coordenadores, os Hemocentros Regionais e os Núcleos de Hemoterapia.

Pertencem ao nível três as Centrais de Triagem Laboratorial dos Doadores, as Unidades de Coleta e Transfusão e as Unidades de Coleta.

Pertencem ao nível quatro as agências transfusionais.

O item P. 1 da RDC/Ms no 153/04 prevê que todo serviço de hemoterapia deve possuir um manual técnico com a descrição dos procedimentos operacionais de todas as atividades inerentes ao chamado "ciclo do sangue".

Para que ocorra o procedimento transfusional é necessário que haja sangue disponível para transfusão, dessa maneira, o primeiro passo a ser dado para que a transfusão de sangue seja realizada é obtenção do sangue.

\subsubsection{DA OBTENÇÃO DO SANGUE}

A disponibilização de sangue para transfusão é originária de doação de sangue voluntária, anônima, altruísta e não-remunerada, direta ou indiretamente" 80 . O candidato à doação deverá se dirigir a um posto de coleta que deverá manter o sigilo sobre a doação.

A RDC/MS n- 153/04 estabelece as condições para que as pessoas possam se candidatar à doação de sangue. Para tanto, o indivíduo deverá: 1) estar em boas condições de saúde; 2) ter entre 18 e 65 anos; 3) pesar no mínimo 50 kg; 4) estar descansado e alimentado (evitar alimentação gordurosa nas quatro horas que antecedem a doação); 5) comparecer a um Posto de Coleta de Sangue com documento original com foto emitido por 
órgão oficial (Carteira de Identidade, Carteira de Trabalho da Previdência Social ou Passaporte) ${ }^{81}$.

São considerados impedimentos temporários para doação de sangue: doenças infecciosas como a gripe, sarampo, rubéola etc.; parto ou cesariana; amamentação; abortamento; ingestão de bebida alcoólica; tatuagem; piercing; a não-utilização de preservativos no ato sexual com parceiros ocasionais ou desconhecidos; a visita, estadia ou residência em regiões onde há alta prevalência de doenças infectocontagiosas como a malária; vacinas de vírus vivos e atenuados ou mortos, toxóides ou recombinante; pessoas que tenham feito sexo em troca de dinheiro ou de drogas; pessoas que foram vítimas de estupro; homens que tiveram relações sexuais com outros homens e/ou as parceiras sexuais destes; homens ou mulheres que tenham tido relação sexual com pessoa com exame reagente para anti-HIV, portador de Hepatite B ou C ou outra infecção de transmissão sexual e sanguínea; pessoas que estiveram detidas por mais de 24 horas em instituição carcerária ou policial; pessoas com parceiros sexuais hemodialisados e/ou pacientes com história de transfusão sanguínea; labirintite; manipulações e extrações dentárias não complicadas; alguns tipos de cirurgias de pequeno, médio e grande portes etc.

Os impedimentos definitivos para doação de sangue são: a evidência clínica ou laboratorial de contaminação de doenças infecciosas transmissíveis pelo sangue, tais como, Hepatite B e C (contraídas após os 10 anos de idade); AIDS (Síndrome da Imunodeficiência Adquirida); doenças associadas ao vírus HTLV I e HTLV II; Doença de Chagas; Malária; uso de drogas ilícitas injetáveis; ter recebido hormônio de crescimento ou outros 
medicamentos de origem hipofisária (entre 1980 e 1996); ter recebido transplante de córnea ou implante de material biológico à base de duramáter; ter história familiar de Encefalopatia Espongiforme Humana; ter permanecido no Reino Unido por mais de seis meses, consecutivos ou intermitentes, de forma cumulativa, de 1/1/1980 a 31/12/1996; ter permanecido em Portugal por 10 ou mais anos, consecutivos ou intermitentes, de forma cumulativa; ter psicose; esquizofrenia; câncer; tuberculose extra-pulmonar; hanseníase; cirurgia cardíaca; gastrectomia total; pneumectomia etc.

Cabe dizer que os homens devem respeitar o intervalo de 60 dias entre uma doação de sangue total e outra, sendo que, podem perfazer no máximo quatro doações por ano, enquanto as mulheres devem respeitar o intervalo de 90 dias entre as doações e devem realizar no máximo três doações de sangue total ao ano.

Existem dois tipos de doação: a autóloga e a heteróloga. A doação é denominada autóloga quando o candidato doar sangue para si mesmo (por exemplo, casos de reserva cirúrgica). A doação é denominada heteróloga quando o doador doar sangue para receptor indefinido.

\subsubsection{DO CADASTRO, AFERIÇÃO DE SINAIS VITAIS, TRIAGEM CLÍNICA E VOTO DE AUTO EXCLUSÃO}

Quando o candidato à doação comparece ao Posto de Coleta de Sangue, após serem realizadas as verificações especificadas anteriormente, ele será cadastrado junto ao banco de dados da instituição coletora, receberá hidratação oral e passará pela avaliação do nível do 
microhematócrito (teste de anemia), aferição dos batimentos cardíacos, da pressão arterial, do peso e da temperatura corporal.

Se o candidato à doação não atingir os parâmetros designados para estes testes, ele não poderá efetuar a doação de sangue. Entretanto, se ele atingir estes parâmetros, estará apto a seguir para a próxima etapa de seleção com profissionais da área de saúde, chamada triagem clínica. Essa triagem consiste na execução de uma entrevista na qual o candidato à doação deverá responder a questões indicadas na RDC/MS nํ153/04, que versam sobre os impedimentos temporários e definitivos já mencionados. Durante a entrevista o candidato deverá ser informado dos riscos da doação. A triagem clínica é realizada no dia da coleta de sangue e deve ser repetida a cada nova doação.

Cumpre esclarecer que o objetivo desses questionamentos é selecionar candidatos à doação considerados de baixo risco para transmissão de doenças infecciosas. As restrições existem para salvaguardar a vida do doador e do receptor e não possuem caráter discriminatório com sentido moral ou religioso. Esses parâmetros são estabelecidos e perquiridos não só pelo Ministério da Saúde como também pela Organização Mundial de Saúde ${ }^{82}$.

Contudo, caso o candidato à doação se enquadre em alguma das situações descritas como impedimentos definitivos ou temporários, ele não efetuará a doação de sangue e deverá ser informado dos motivos da recusa.

Países desenvolvidos adotam uma política mais restritiva que a brasileira em relação à seleção dos candidatos à doação visando manter a segurança transfusional. Nos Estados Unidos, por exemplo, os homens que 
mantiveram apenas uma relação homossexual são impedidos definitivamente de doar sangue, enquanto aqui no Brasil este é um impedimento temporário, ou seja, os homens que mantiveram relação homossexual ficam impedidos de doar sangue apenas por doze meses, contados da data do ato sexual.

Encerrada a triagem clínica, o item B.6.2 da RDC/MS nำ153/04 prevê que os serviços de hemoterapia deverão oferecer ao candidato à doação a oportunidade de se autoexcluir, revendo sigilosamente sua condição, frente ao risco de transmissão de doenças sexualmente transmissíveis (DSTs).

Com isso, se o candidato à doação tiver omitido e/ou mentido sobre algum dado importante durante a triagem clínica e entender que sua vida pregressa oferece risco de transmissão de doenças infecciosas, ele poderá descartar "sigilosamente" sua própria bolsa de sangue. Cabe dizer que, cada Serviço de Hemoterapia poderá, a seu critério, aplicar um método de autoexclusão.

Os pontos críticos destas etapas são:

a) Cadastro: algum candidato à doação poderá adulterar documento oficial com foto, para se fazer passar por outra pessoa, que pode ocasionar erro na vinculação de informações do candidato e acarretar problemas na segurança transfusional, considerando que em muitos programas informatizados de gerenciamento de atividades técnicas os serviços de hemoterapia atrelam as informações pessoais, comportamentais e de parentesco dos doadores; pode haver falha na digitação ou na grafia de alguma informação; falha do programa informatizado que cria novo cadastro 
do doador se houver erro de digitação ou de grafia; falha do programa informatizado que não busca adequadamente informações nos seus bancos de dados e cria um novo cadastro do candidato à doação a cada comparecimento do candidato para efetuar uma nova doação; o candidato à doação pode mentir ou omitir informações sobre os impedimentos definitivos ou temporários.

b) Aferição de sinais vitais: pode haver erro na aferição dos sinais vitais que são indicativos excludentes da doação, tanto para salvaguarda da integridade do candidato à doação (baixo hematócrito) como para salvaguarda do receptor (febre - que pode sugerir uma contaminação ou infecção). Portanto, faz-se necessário que todos os aparelhos estejam corretamente calibrados, bem como que essa calibração ocorra periodicamente.

c) Triagem clínica: o candidato à doação pode omitir e/ou mentir sobre seu comportamento, o que impedirá que os profissionais da área de saúde que realizarem a entrevista possam identificar o risco potencial do candidato, e com isto, podem não recomendar o descarte da bolsa de sangue que poderá contaminar os receptores. Assim como ocorre no cadastro, alguns candidatos podem insistir para perfazer a doação de sangue com 0 intuito de obter a testagem sorológica gratuita ${ }^{82}$ e sem prescrição médica e/ou para receber atestado para abono de falta no emprego, nos termos dispostos no inc. IV, do art. 463 da Consolidação das Leis do Trabalho $(\mathrm{CLT})^{84}$.

d) Método de autoexclusão: os candidatos à doação podem mentir sobre seu comportamento, e/ou o candidato à doação pode não 
entender a importância do descarte da bolsa com risco potencial de contaminação inerente à transfusão de sangue.

\subsubsection{DA COLETA}

Após a realização do método de autoexclusão, o candidato deverá assinar um termo de consentimento livre e esclarecido para doação, testagem e, se necessário, para realização de pesquisas clínicas (observância da Resolução do Conselho Nacional de Saúde no 196/96 ${ }^{85}$ ) e, posteriormente, será encaminhado para execução da coleta do sangue.

A coleta do sangue e de seus componentes pode ser feita por dois métodos: coleta direta de sangue total - comum, que explicaremos mais adiante ou processo de aférese.

Aférese é um procedimento de coleta de sangue do doador, por meio do qual um equipamento especial centrifuga o sangue total coletado do doador, separando somente o(s) componente(s) desejado(s) e, após a separação e retirada do(s) produto(s) desejado(s), o equipamento devolve ao organismo o(s) outro(s) componente(s) não solicitado(s). Para a realização dessa coleta de sangue específica são utilizados "kits" estéreis, descartáveis e não-reutilizáveis. O componente retirado já sai filtrado, sendo que os demais procedimentos (testagem sorológica e imunohematológica, estocagem, aliquotagem, liberação e transportes) devem acontecer normalmente, como veremos a seguir. Por esse método são obtidos principalmente os concentrados de granulócitos (CG) e concentrados de plaquetas (CP). 
Antes de iniciar a coleta, seja ela direta de sangue total comum ou por aférese, o profissional da área de saúde responsável, verificará o melhor acesso venoso do candidato à doação para coleta de sangue e amostras. Existem situações em que o candidato não possui acesso venoso adequado para coleta de sangue e amostras, sendo esse um fator impeditivo para doação. Então, o candidato à doação será orientado a retornar à triagem clínica para que the seja explicado o motivo da recusa. Se o candidato possuir acesso venoso adequado, o profissional da área da saúde executará a desinfecção do local da punção com degermante e antisséptico, em seguida fará a punção venosa e procederá à coleta do sangue e das amostras no tempo e quantidade indicados. A RDC/MS nํㅜ 153/04 determina que a coleta de sangue deverá ser feita com uma só punção, com tempo máximo de 15 minutos, e deve ser realizada em um sistema de coleta fechado e estéril, com bolsas plásticas específicas para armazenamento de hemocomponentes.

A quantidade de sangue a ser retirada do doador é de aproximadamente $450 \mathrm{~mL}$, sendo que desse valor a coleta não poderá exceder $8 \mathrm{~mL} / \mathrm{kg}$ para mulheres e $9 \mathrm{~mL} / \mathrm{kg}$ para homens ${ }^{86}$.

Durante todo o período da coleta, independentemente de ser de sangue total comum ou por aférese, o doador deverá ser acompanhado por um profissional da área da saúde, supervisionado por médico ou enfermeiro, em razão de que podem ocorrer reações adversas durante o procedimento.

Após a coleta do sangue serão retiradas amostras de sangue para análise e será feito um curativo no local da punção, sendo que o doador 
deverá permanecer no posto de coleta no mínimo por quinze minutos para identificação de possíveis reações adversas à doação ${ }^{79}$.

Embora a maior parte das doações transcorra sem qualquer complicação, ocasionalmente algum doador poderá apresentar reação adversa à doação. Estima-se que $1 \%$ dos doadores tenha esta intercorrência ${ }^{85}$. A maioria das complicações são reações vaso-vagais (fluxo sanguíneo lento). Essas reações também podem ocorrer como resultado de influências psicológicas, em razão da visão do sangue, como também, excitação, medo ou apreensão sobre o procedimento ou, ainda, podem constituir uma resposta neurofisiológica à doação. As reações adversas à doação são classificadas em três categorias: leve, moderada e severa.

As reações leves são caracterizadas pelos seguintes sinais e sintomas: nervosismo; ansiedade; queixa de calor; palidez e sudorese; frequência cardíaca diminuída e pulso filiforme; hiperventilação; hipotensão; náusea e/ou vômito sem perda de consciência.

As reações moderadas são caracterizadas pelo agravamento dos sintomas descritos nas reações leves, somadas à perda da consciência.

As reações graves apresentam os mesmos sinais e sintomas mencionados na reação moderada, acrescidas de convulsões e/ou problemas cardíacos e/ou respiratórios.

Findo o procedimento de doação, o doador será orientado a: 1) evitar dobrar o membro superior puncionado por 30 minutos; 2) evitar esforços físicos exagerados durante as 12 horas posteriores à doação; 3) aumentar a ingestão de líquidos nas 4 horas após a doação; 5) evitar ingestão de bebida alcoólica por pelo menos 12 horas após doação; 6) evitar fumar por 2 horas 
após a doação; e 7) manter curativo no local da punção por pelo menos 4 horas. Terminadas as orientações, o doador receberá um lanche e, após esta refeição, se aparentar boas condições de saúde, poderá ser dispensado.

Vale dizer que, neste momento, o banco de sangue deverá possuir um sistema/programa efetivo e confiável para centralizar/vincular as informações dos dados pessoais do doador, do método de autoexclusão, dos tubos de amostras, da bolsa de sangue e dos resultados sorológicos e imunoematológicos para que eles sejam adequadamente correlacionados. $\bigcirc$ erro na adequada vinculação representa a perda da rastreabilidade dos produtos e da segurança transfusional. Exemplo 1: O doador "X" passou pela triagem clínica e foi considerado apto a doar. No método de autoexclusão ele optou por se autoexcluir, o que significa que ele oferece risco de transmissão de doenças infecciosas aos receptores de sangue. Ele procedeu à coleta de sangue e amostras, mas em razão do método de autoexclusão positivo, a bolsa de sangue doada por ele deverá ser descartada. Exemplo 2: O doador "Y" passou pela triagem clínica e foi considerado apto a doar. No método de autoexclusão ele optou por não se autoexcluir, o que significa que ele não oferece risco de transmissão de doenças infecciosas aos receptores de hemocomponentes. Ele procedeu à coleta de sangue e amostras e o resultado dos testes sorológicos das amostras foi reagente (positivo) para alguma doença. Neste caso também, a bolsa de sangue deverá ser descartada. Em ambos os casos será o sistema/programa que deverá cruzar todas as informações e fornecer uma 
conclusão confiável, visando a garantia da rastreabilidade do processo e da segurança transfusional.

Há que se mencionar que a utilização de um sistema informatizado validado (por instituições competentes) e confiável contribuirá significantemente para redução de falhas humanas que podem ocorrer na transcrição e vinculação de informações.

Os pontos críticos dessa etapa são:

a) Contaminação bacteriana na bolsa de sangue em razão de inadequada desinfecção e antissepsia do local da punção venosa.

b) Erro na vinculação da bolsa de sangue com os respectivos tubos de amostra, além das informações pessoais do doador (se o local for informatizado, isto pode ocorrer por falha do sistema, e se não for informatizado, por falha humana).

c) Coleta de volume adequado de sangue do doador para evitar prejuízos à saúde do doador.

d) Qualidade dos insumos, principalmente da bolsa de sangue que armazenará o sangue coletado.

e) Falha humana no acompanhamento das reações à doação que pode causar prejuízos à saúde do doador.

\subsubsection{DA TRIAGEM SOROLÓGICA}

Terminada a coleta de sangue, os tubos de amostras do sangue coletado seguirão para testagem sorológica e imunohematológica, ao passo que as bolsas de sangue seguirão para o processamento. 
Um dos tubos de amostra coletados seguirá para rotina de testagem sorológica no mesmo dia da coleta. Sendo que, nessa amostra, serão realizados obrigatoriamente a triagem sorológica para: Hepatite B (HBV); Hepatite C (HCV); Vírus da Imunodeficiência Humana HIV-1 e HIV-2; Doença de Chagas; Sífilis; HTLV I e HTLV II. Em regiões endêmicas de Malária é obrigatória a realização da triagem sorológica para a doença. Recomenda-se a testagem do sangue para Citomegalovírus (CMV) para receptores de sangue que serão submetidos à transplante de órgão, com sorologia não-reagente para CMV ou recém-nascidos com peso inferior a $1.200 \mathrm{Kg}$ ao nascer, de mães CMV negativo ou com resultado sorológico desconhecido. É importante dizer que a ANVISA não autoriza a realização dos exames mencionados em "pool" de amostras, e no caso de haver uma nova tecnologia diagnóstica com eficiência comprovada a ANVISA avaliará a possibilidade de autorização de teste em "pool" de amostras.

A Portaria MS no 488 de 17 de junho de 1998, estabeleceu uma rotina obrigatória de procedimentos sequenciados para identificar a presença de anticorpos anti-HIV nas amostras de sangue dos doadores. Este processo tem por finalidade o aumento de confiabilidade nos resultados sorológicos obtidos, bem como a redução da ocorrência de resultados falso-positivos ou falso-negativo ${ }^{83}$. Nessa fase, as amostras são submetidas a dois testes distintos realizados paralelamente. Se os resultados dos dois testes forem negativos ou não-reagentes, o exame será liberado como "Amostra negativa para HIV". Em uma segunda situação, se os resultados de ambos os testes forem positivos ou reagentes para HIV, os testes serão remetidos à confirmação sorológica nos termos da Portaria MS nำ 59/2003, ou seja, 
serão realizados os testes Elisa (EIA) e/ou Imunofluorescência Indireta (IFI) e/ou Western Blot (WB).

Neste caso, uma nova amostra do paciente deverá ser coletada para atestar a positividade e, se essa retestagem confirmar que a amostra é reagente para HIV, o exame será liberado como "Amostra positiva para HIV". Em uma terceira situação, se os resultados das amostras dos dois testes distintos realizados paralelamente forem discordantes, o procedimento deverá ser repetido em duplicata. Sendo o resultado, por fim, negativo, o exame será liberado como "Amostra negativa para HIV" ou sendo positivo haverá o procedimento de confirmação diagnóstica, mencionado no parágrafo anterior, até que se ateste finalmente, sendo o exame liberado como "Amostra positiva para HIV".

A questão principal dos testes sorológicos é o risco de contaminação residual por doenças infectocontagiosas ${ }^{87,88}$. A literatura especializada atribuiu seis ocorrências que podem contribuir isoladamente ou em conjunto para esses resultados:

O primeiro problema é o erro estimado. Os testes/reagentes devem ser, obrigatoriamente, de "alta especificidade". Mas, mesmo assim, não chegam a $100 \%$ de certeza do resultado, os mais acurados chegam a $99,8 \%$ de certeza. Isto quer dizer que, de 1.000 resultados obtidos, dois podem estar errados.

O segundo problema é o fenômeno denominado "janela imunológica" ou fase pré-soroconversão, na qual, após um indivíduo ser contaminado por um vírus ou bactéria, o organismo apresenta um lapso temporal para reagir e produzir uma quantidade suficiente de anticorpos necessários para serem 
detectados nos exames sorológicos. Esse período é chamado de janela imunológica. Para o HIV esta fase é de 22 dias, para HCV é de 72 dias, para HBV é de 56 dias, para HTLV I é de 84 dias. Neste intervalo de tempo, mesmo que os testes não sejam reagentes para a doença o sangue já estará contaminado e apto a transmitir essas doenças.

O terceiro problema é a soroconversão atípica, também denominada soroconversão tardia. Existem casos relatados na doutrina médica de soroconversão de HIV após nove meses da data do contágio, em vez do que ocorre comumente em 22 dias. Os estudiosos dessa área dizem que este atraso da soroconversão se dá em razão da infecção ocupacional concomitante de HIV e HCV ou pela resposta retardada ou ausente logo no início da contaminação ou em estágios avançados da doença ${ }^{89}$. Nesse caso também, mesmo que os testes não se apresentem reagentes para a(s) doença(s) o sangue já estará contaminado e apto a transmiti-la(s).

O quarto problema são as variantes virais ${ }^{90}$. Os vírus e as bactérias são mutantes. Contudo, se atualmente dispomos de tecnologia para determinar a presença de determinado antígeno, há a possibilidade de ele sofrer uma mutação com possíveis diferenças de índices de transmissibilidade e patogenicidade e deixar de ser reconhecido pelos testes de detecção de anticorpos. Portanto, mesmo que o antígeno não seja reconhecido, ele transmitirá a doença numa transfusão sanguínea.

O quinto problema é o erro laboratorial. Durante o processo de testagem podem haver as seguintes probabilidades de erros: troca de amostras; erro na leitura dos dados; erro na transcrição dos dados; falta de calibração adequada dos equipamentos, que ocasionam falha no resultado 
da reação; contaminação dos equipamentos e insumos, que também causam erro no resultado da reação etc. Sendo que o resultado errôneo poderá se refletir na liberação da bolsa contaminada.

O sexto problema é o controle de qualidade dos "kits" de sorologia utilizados. A Portaria MS nำ 2458/03, estabelece um protocolo de testagem da qualidade dos "kits" sorológicos utilizados, para evitar a falibilidade dos testes. Isto porque a qualidade dos testes pode variar no processo de produção, na qualidade dos insumos, no modo de transporte e no armazenamento. Para tanto, se a norma for seguida com rigor, e os bancos de sangue testarem lote a lote a qualidade de seus "kits", esse problema poderá ser facilmente solucionado.

Existe uma técnica que já vem sendo utilizada nos Estados Unidos da América desde 2001, denominada NAT (Nucleic Acid Test), que reduz o período de janela imunológica dos vírus $\mathrm{HIV}^{91}, \mathrm{HCV}^{92}, \mathrm{HBC}^{93}$. Este método de detecção é baseado na amplificação exponencial da carga genética do vírus, que permite a identificação genômica do vetor em período reduzido de identificação-padrão da viremia ${ }^{94}$. Ele pode ser feito por PCR (reação cadeia polimerase) chamada PCR-RT ou pelo método Quantiplex bDNA (teste ramificado $A D N)^{95}$. A detecção do $\mathrm{HIV}$, por exemplo, passa de aproximadamente 22 para 11 dias, do HCV de 72 para 11 dias, da Hepatite B de 56 para 31 dias. Weusten et al. (2002) ${ }^{96}$ elaboraram um modelo matemático para quantificar o risco de contaminação residual, mesmo com a utilização do NAT.

Como informamos anteriormente, o Ministério da Saúde desde 2002 busca implementar a realização desses testes em todos os serviços de 
hemoterapia do país, mas até este momento somente alguns serviços privados os realizam em suas rotinas de testagem. Contudo, contabilizando a magnitude de transfusões que são feitas a partir de hemocomponentes coletados por instituições públicas, filantrópicas e privadas, que atendem ao SUS, conclui-se que o risco de contaminação residual é notório, partindo da premissa de que o próprio Ministério da Saúde (gestor da saúde pública), há mais de sete anos, reconheceu a eficácia do método na diminuição da fase pré-conversão (janela imunológica).

Cabe esclarecer que os serviços de hemoterapia podem controlar tão e somente a soroconversão (alteração da sorologia de negativa para positiva), de pessoas que já doaram sangue em suas dependências.

Quando ocorre uma soroconversão, o Serviço de Hemoterapia que identificou a reação deverá iniciar a retrovigilância dos hemocomponentes do doador que soroconverteu. A retrovigilância é a identificação dos pacientes que receberam transfusão dos hemocomponentes doados pela pessoa que soroconverteu e a comparação sorológica das amostras dos pacientes e do doador contaminado com a respectiva notificação da reatividade à autoridade sanitária competente.

Caso algum dos hemocomponentes com sorologia positiva tenha sido enviado para o fracionamento industrial, como o plasma para produção de fatores de coagulação, estas empresas e a autoridade sanitária federal devem ser comunicadas sobre a soroconversão.

Quando houver a soroconversão do doador, a(s) bolsa(s) doada(s) por ele deve(m) ser descartada(s) ou encaminhada(s) para produção de painéis de controle sorológico. 


\subsubsection{DA TRIAGEM IMUNOHEMATOLÓGICA}

A descoberta do sistema $\mathrm{ABO}$ por Landsteiner, que originou a imunohematologia, foi tão significante para a medicina transfusional, que atualmente a incompatibilidade $\mathrm{ABO}$ é um dos principais problemas das transfusões. Além da descoberta do sistema ABO/Rh desde 1901, foram reconhecidos outros 262 antígenos na membrana eritrocitária ${ }^{97}$.

Contudo, a importância da negatividade sorológica para doenças transmissíveis pelo sangue está em igual patamar à importância da compatibilidade do sangue que será infundido no receptor, em relação à tipagem do doador.

Nesse caso, enquanto uma amostra do sangue doado é analisada sorologicamente, a outra amostra seguirá para a testagem imunohematológica, que tem por objetivo determinar a tipagem e fenotipagem da bolsa de sangue doada.

O sistema $A B O$ é definido pela presença ou ausência dos antígenos $A$ e B isolada ou simultaneamente na superfície (membrana) da hemácia do doador.

Os antígenos que compõem a membrana eritrocitária são formados por proteínas ou carboidratos. Eles possuem seus anticorpos correspondentes e esse complexo sistema de correlações deve ser bem avaliado para manutenção da segurança transfusional e a integridade do paciente/receptor. 
Os anticorpos relativos à tipagem $\mathrm{ABO}$ são chamados naturais (Imunoglobulina M). Eles surgem sem que haja resposta imune do organismo, em relação à inoculação de algum antígeno externo.

Os outros anticorpos presentes no sangue de um indivíduo, chamados de imunes (Imunoglobulina G), são aqueles que surgiram após uma reação imune do organismo a um antígeno externo. Esses anticorpos variam em imunogenicidade, frequência e importância clínica. A imunogenicidade é a capacidade de reação e indução de resposta imunológica que varia de acordo com a quantidade de determinante antigênico (epitopo). Portanto, nem todo antígeno tem imunogenicidade.

Após a recepção da amostra do sangue, o laboratório de imunohematologia iniciará sua rotina, que pode ser feita através das técnicas de tubo, gel, microplacas ou automação. A RDC/MS nํ153/04 determina a realização de prova direta e prova reversa nas amostras de sangue.

A tipagem direta é a pesquisa realizada para determinar a presença dos antígenos A e B nas hemácias do doador, enquanto a tipagem reversa é a pesquisa dos anticorpos correspondentes ao antígenos $\mathrm{A}$ e $\mathrm{B}$ no soro ou plasma do doador ${ }^{97}$.

Para realizar a prova direta, a amostra de sangue do doador é centrifugada, visando a separação das hemácias do soro. Com uma determinada quantidade dessas hemácias é feita uma solução. Em recipientes separados são adicionados respectivamente: soro Anti-A (que apresentam universalmente a coloração azul), soro Anti-B (que apresentam universalmente a coloração amarela), soro Anti-AB (que apresentam 
universalmente a coloração laranja). A aglutinação ou não da solução com os soros determinará a tipagem sanguínea.

A prova reversa é feita com o soro da mesma amostra do doador. Ao soro do doador são adicionadas, em recipientes separados, hemácias conhecidas A e B (vendidas comercialmente). Da mesma maneira, se houver ou não aglutinação será determinada a tipagem sanguínea.

Para tanto, a identificação dos resultados se dará da seguinte forma:

Quadro 1 - Classificação da determinação de tipagem ABO pelo método de aglutinação.

\begin{tabular}{|c|c|c|c|c|c|}
\hline Grupo ABO & Soro anti-A & Soro anti-B & Soro anti-AB & $\begin{array}{l}\text { Hemácias } \\
\text { Comerciais A }\end{array}$ & $\begin{array}{l}\text { Hemácias } \\
\text { Comerciais } \\
\text { B }\end{array}$ \\
\hline$A$ & + & - & + & - & + \\
\hline B & - & + & + & + & - \\
\hline$A B$ & + & + & + & - & - \\
\hline $\mathrm{O}$ & - & - & - & + & + \\
\hline
\end{tabular}

Vale dizer que se os resultados das provas direta e reversa estiverem contraditórios, novos testes ou investigações adicionais deverão ser realizados para determinar com segurança a tipagem $A B O$ do doador.

O antígeno $D$ é altamente imunogênico e não existem anticorpos naturais contra ele. Os anticorpos que por ventura forem identificados nos doadores são resultantes de sensibilização prévia, que pode ocorrer em virtude de transfusão incompatível, gravidez ou aborto, nos quais a mãe seja Rh negativo e o feto $\mathrm{Rh}$ positivo.

Para a realização da rotina de testagem para verificação do antígeno D, adiciona-se soro Anti-D, as hemácias em solução e fazendo-se 
paralelamente o controle. Se houver aglutinação, a tipagem será concluída como Rh positiva. Porém, se a amostra não aglutinar a pesquisa prosseguirá para verificação do antígeno D fraco.

A interpretação dos resultados deverá ser:

\begin{tabular}{lcc} 
Quadro 2 - Classificação da tipagem Rh pelo \\
método de aglutinação. \\
\hline Grupo Rh & Soro anti-D & Controle Rh \\
\hline Positivo & + & - \\
Negativo & - & - \\
\hline
\end{tabular}

Além da determinação da tipagem $\mathrm{ABO}$ e $\mathrm{Rh}$ das bolsas de sangue coletadas, também é realizada a pesquisa de anticorpos irregulares (PAI). Esta testagem tem por objetivo definir a existência ou não de anticorpos irregulares ( $\lg G$ ) no soro ou no plasma do doador que podem ocasionar hemólise no receptor.

Essa triagem pode ser feita por intermédio das técnicas de tubo, gel, microplacas ou automação. Amostras do soro do doador são adicionadas a hemácias comerciais com um fenótipo conhecido (Kell, Duffy etc.). Do mesmo modo que ocorre nas demais provas de imunohematológicas anteriormente citadas, caso haja aglutinação, entende-se que determinado anticorpo está presente no sangue do doador. Com o resultado positivo da pesquisa de anticorpos irregulares, os componentes eritrocitários poderão ser disponibilizadas com a indicação dos fenótipos presentes, caso haja necessidade de conferência da compatibilidade fenotípica, todavia, os componentes plasmáticos não poderão ser utilizados. 
Os pontos críticos da triagem imunohematológica são: troca de amostras; erro na leitura dos dados; erro na transcrição dos dados; falta de calibração adequada dos equipamentos que ocasionam erro no resultado da reação; contaminação dos equipamentos e insumos, que também causam erro no resultado da reação; não utilização de técnica adequada; qualidade dos insumos etc.

\subsubsection{DO PROCESSAMENTO}

Conforme dito anteriormente, após o término da coleta, a bolsa de sangue total segue para o processamento.

O processamento da bolsa de sangue total é feito para separar os constituintes do sangue. O sangue é formado por: a) hemácias (eritrócitos ou glóbulos vermelhos), células em forma de disco bicôncavo e anucleado com coloração vermelha (hemoglobina) que têm a função de realizar as trocas gasosas em todo o organismo. São as mais numerosas do sangue. Em indivíduos adultos com condições normais de saúde são encontradas aproximadamente entre 4,5 a 6,5 milhões de células por $\mathrm{mm}^{3}$ de sangue, sendo que elas vivem em média 120 dias $^{98}$; b) leucócitos (glóbulos brancos), que são subdivididos em cinco tipos: linfócitos, neutrófilos, eosinófilos, basófilos e monócitos. Cada uma destas células tem uma função definida, entretanto, os leucócitos de uma maneira geral têm o objetivo de defender o organismo de microorganismos estranhos por meio da produção de anticorpos ou por captura. Em indivíduos adultos com condições normais de saúde são encontradas em média de 4.000 a 11.000 de leucócitos por mm ${ }^{3}$ 
de sangue ${ }^{99}$; c) plaqueta (trombócito),é um fragmento celular da célula megacariócito, localizada na medula óssea. Em indivíduos adultos com condições normais de saúde são encontradas em média de 150.000 a 400.000 de plaquetas por $\mathrm{mm}^{3}$ de sangue. Sua função é interromper a perda sanguínea, por meio da formação de coágulos (trombos) ${ }^{100}$; d) plasma é o componente líquido e acelular do sangue, onde as células ficam suspensas. Ele é formado por $91 \%$ de água, $7 \%$ de proteínas (albumina, fibrinogênio e globulinas) e os demais $2 \%$ correspondem a substâncias, tais como, enzimas, anticorpos, hormônios, vitaminas, glicose, sódio, potássio, cálcio e fosfatos, dentre outras. Ele corresponde a $55 \%$ do volume total do sangue e é responsável pelo transporte das células do sangue e das demais substâncias por todo o organismo ${ }^{101}$.

Nessa etapa do ciclo do sangue, a bolsa de sangue total, ao ser entregue pelo setor de coleta ou Serviço de Hemoterapia coletor ao local de processamento fracionamento, deverá ser submetida à pesagem para seleção das bolsas que serão preparadas.

Após a separação por meio do critério de pesagem, as bolsas de sangue total deverão aguardar uma hora para serem novamente manipuladas e, a partir de então, poderão seguir para sedimentação espontânea ou para centrifugação, com o objetivo de haver a separação dos componentes do sangue. Cabe dizer que o processo de centrifugação deve obedecer a um padrão de força gravitacional, tempo e temperatura, baseado na densidade das células, para que estas não sejam comprometidas (hemólise). 
Por meio desse procedimento são obtidos os seguintes hemocomponentes com as seguintes condições mínimas: a) concentrado de hemácias $(\mathrm{CH})$, que é preparado a partir da bolsa de sangue total da qual é retirada uma porção de plasma. Nela conterá hemácias, pouco plasma, leucócitos e plaquetas e deverá apresentar hematócrito entre 65\% a 80\% em solução CPDA 1 e entre $50 \%$ e $70 \%$ com solução aditiva. $\mathrm{O} C H$ tem durabilidade aproximada de 35 a 42 dias, dependendo da solução conservante contida na bolsa; b) plasma fresco congelado (PFC), que é o plasma separado de uma unidade de sangue total por centrifugação e totalmente congelado em até 8 horas da coleta em temperatura mínima de $20^{\circ} \mathrm{C}$ ou inferior. É composto pelos fatores de coagulação lábeis presentes no sangue. De acordo com a RDC/MS nำ153/04, o PFC tem validade de doze meses se armazenado em temperatura igual ou inferior a $-20^{\circ} \mathrm{C}$ ou vinte e quatro meses se armazenado entre $-20^{\circ}$ e $-30^{\circ} \mathrm{C}$; c) plasma simples (PS), que é o plasma separado de uma unidade de sangue total por centrifugação e congelado após 8 horas da coleta. O PS tem validade de quatro anos se armazenado em temperatura igual ou inferior a $-20^{\circ} \mathrm{C}$; d) concentrado de plaquetas $(\mathrm{CP})$, obtido por meio da centrifugação da bolsa de sangue total. Após retirado o concentrado de hemácias é realizada nova centrifugação para se fazer a separação das plaquetas e do plasma. O CP é constituído por de plaquetas, leucócitos e plasma, sendo que ele deve ter um volume entre 50 e $70 \mathrm{~mL}$, contagem plaquetária de $5 \times 10^{10}$ por unidade de sangue total e de $3 \times 10^{11}$ por unidade de aférese e $\mathrm{pH}$ de 6,2 no último dia da validade. O CP tem durabilidade aproximada de 3 a 5 dias; e) crioprecipitado (CRIO) é a fração insolúvel em frio do plasma. Ele é obtido 
pelo congelamento do plasma fresco congelado, seguido de descongelamento e centrifugação para separação desta substância. É composto pelas seguintes proteínas plasmáticas: fator VIII, fator $\mathrm{V}$ e fibrinogênio. O CRIO tem validade de doze meses se armazenado em temperatura igual ou inferior a $-20^{\circ} \mathrm{C}$ ou de vinte ou quatro meses se armazenado entre $-20^{\circ}$ e $-30^{\circ} \mathrm{C}$.

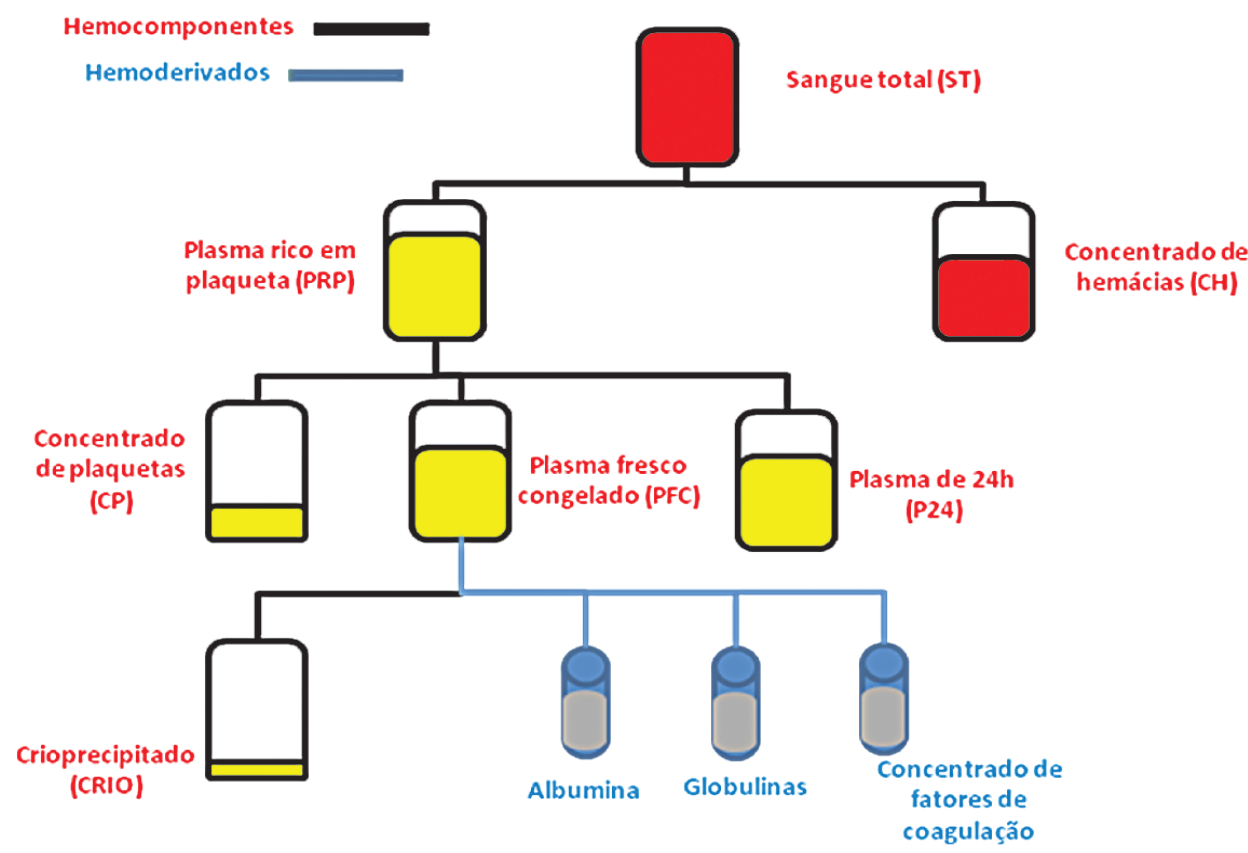

Figura 1 - Esquema de processamento da bolsa de sangue total ${ }^{102}$

Além dos componentes mencionados, pela doação de sangue podem ser obtidos: a) concentrado de granulócitos (obtidos por aférese); b) concentrado de hemácias rejuvenescidas; c) concentrado de hemácias congelado; d) plasma isento de crio (PIC).

Após a separação dos hemocomponentes eles serão armazenados na chamada quarentena, para aguardar os resultados sorológicos e 
imunoematológicos, e assim, poderem ser liberados para transfusão quando solicitados por meio das requisições de transfusão de sangue que falaremos oportunamente.

Cabe dizer que os serviços de hemoterapia devem possuir um controle de qualidade sobre todos os componentes sanguíneos produzidos $^{103,104}$, com protocolos escritos de atividade. A RCD/MS nํ 153/04 determina que $1 \%$ da produção ou dez unidades, o que for maior, sejam testadas por mês. No caso do plasma, ao menos quatro de suas unidades de plasma e o crio devem ser avaliados ao mês. O percentual mínimo de conformidade do controle de qualidade dos componentes deve ser igual ou maior do que $75 \%$, com exceção do percentual de esterilidade que deve ser igual ou maior do que $99,4 \%$.

Os pontos críticos do processamento são:

a) Contaminação bacteriana na bolsa de sangue em razão de inadequada manipulação ou antissepsia dos equipamentos.

b) Falha humana no exercício das atividades.

c) Processo inadequado de produção.

d) Falta de calibração e manutenção dos equipamentos.

e) Processo inadequado de manipulação.

\subsubsection{DO MANUSEIO, ARMAZENAMENTO, ROTULAGEM, TRANSPORTE E PROCEDIMENTOS NOS HEMOCOMPONENTES}

O cuidado em relação ao manuseio, armazenamento e transporte dos hemocomponentes deve ser observado para prevenir a ocorrência de danos 
físicos e químicos aos elementos celulares e plasmáticos, bem como, para redução da contaminação e proliferação bacteriana.

Como já exposto, os componentes sanguíneos podem ser comprometidos por contaminação bacteriana ocorrida durante a punção venosa, em razão da antissepsia do local e/ou porque a bactéria já estava presente no organismo do doador antes da doação. Contudo, se não houver a refrigeração adequada dos hemocomponentes será dispoibilizado o ambiente propício para multiplicação das bactérias. Portanto, a refrigeração correta minimiza a proliferação de bactérias.

Nesse sentido, os componentes sanguíneos devem ser conservados em geladeira, freezer, câmara fria ou incubadora de plaquetas (com agitação constante), dependendo das especificações técnicas de armazenagem. Toda a cadeia de frio dos serviços de hemoterapia deve estar calibrada e validada periodicamente, além de possuir alarmes sonoros, que devem ser testados, no mínimo a cada três meses.

A temperatura ideal para o armazenamento dos componentes eritrocitários (com exceção do concentrado de hemácias congelado) será entre $2^{\circ} \mathrm{C}$ e $4^{\circ} \mathrm{C}$, para os componentes plaquetários entre $20^{\circ} \mathrm{C}$ e $22^{\circ} \mathrm{C}$, e para os componentes plasmáticos e crioprecipitado $-20^{\circ} \mathrm{C}$ ou menos ${ }^{105}$.

A rotulagem dos hemocomponentes deve ser observada com rigor para assegurar sua rastreabilidade, desde a obtenção do sangue até a infusão da última gota do hemocomponente no receptor, como também, para demonstrar as características do hemocomponente. A RDC/MS nำ 153/04 estabelece que os rótulos devem estar firmemente aderidos à bolsa e de modo a não ser possível a remoção após a fixação. Os rótulos devem conter 
informações em sistema numérico ou alfanumérico que não possam ser adulterados. Se não houver sistema informatizado implantado no Serviço de Hemoterapia, o controle de rotulagem deverá ser feito por duas pessoas. Se houver sistema informatizado as informações deverão ser disponibilizadas por códigos de barras.

Os rótulos dos hemocomponentes devem conter as seguintes informações: nome e endereço da instituição coletora do sangue; nome e volume aproximado do hemocomponente; identificação alfanumérica que permita a rastreabilidade do produto; nome e quantidade de anticoagulante; e se for o caso, a inscrição "doação autóloga".

O transporte adequado dos hemocomponentes também deve ser rigorosamente seguido para que não haja nenhum tipo de comprometimento. Os hemocomponentes que contenham hemácias devem ser transportados em compartimento térmico, com temperatura entre $1^{\circ} \mathrm{C}$ e $10^{\circ} \mathrm{C}$; os que contenham plaquetas também devem ser transportados em compartimento térmico, com temperatura entre $20^{\circ} \mathrm{C}$ e $24^{\circ} \mathrm{C}^{106}$; e os hemocomponentes congelados devem ser transportados de maneira que conservem 0 congelamento.

A não observação destes limites ou a apresentação de alguma alteração físico-química visível no hemocomponente ensejará o descarte do mesmo, para que não haja prejuízos ao receptor.

Alguns médicos solicitam hemocomponentes com especificações procedimentais, em razão das condições clínicas do paciente. São elas: a) filtração; b) lavagem; c) irradiação; d) aliquotagem. Considerando-se que em um hemocomponente pode ser realizado mais de um procedimento dos 
mencionados, como por exemplo, um concentrado de hemácias filtrado e lavado (CHFL) ou um concentrado de hemácias filtrado, irradiado e aliquotado (CHFIA). A rotina de realização desses procedimentos depende do critério/protocolo estabelecido pelo Serviço de Hemoterapia, e, desta forma, deverão ser solicitados pelo médico com certa antecedência para que estejam disponíveis dentro do prazo que for necessária a transfusão.

Note-se que o controle do estoque é um processo criterioso, uma vez que o abastecimento de hemocomponentes depende da doação de sangue voluntária, altruísta e não-remunerada. Desta forma, as ferramentas que os hemocentros dispõem para abastecer seus estoques são a divulgação na mídia da falta de hemocomponentes e o convite às pessoas que já doaram sangue (com sorologia negativa) para retornar aos postos de coleta. Concluindo-se que esse problema vai se refletir diretamente na disponibilidade de hemocomponente para transfusão, porque, uma vez que haja escassez de produto, sua distribuição deverá ser racionalizada e haverá possibilidade de não atendimento de pedidos médicos de solicitação de hemocomponentes.

Por racionalização entenda-se análise e discussão médica da indicação transfusional feita entre o médico hemoterapeuta do Serviço de Hemoterapia que vai liberar o hemocomponente para uso e o médico que está solicitando o hemocomponente para transfusão, com vistas a priorizar as situações clínicas mais graves e urgentes. Veja, não há uma forma imperativa e cogente dos serviços de hemoterapia obrigarem as pessoas a doar sangue. Ao contrário, como dissemos anteriormente, a lei que dispõe sobre a atividade hemoterápica proíbe tal conduta, e, no entanto, os serviços 
de hemoterapia podem ser eventualmente questionados judicialmente pela não entrega de produto indisponível.

Os pontos críticos destas etapas são:

a) Manuseio: brusca movimentação; alocação dos hemocomponentes em recipiente contaminado; falta de refrigeração dos hemocomponentes.

b) Armazenamento: falha humana na armazenagem em temperatura fora da especificada; falha dos equipamentos da cadeia de frio; guarda dos hemocomponentes em local contaminado.

c) Rotulagem: falha humana na transcrição de informações; falha humana na execução da atividade; falha na emissão de rótulos; troca de rótulos.

d) Transporte: brusca movimentação; alocação dos hemocomponentes em recipiente contaminado; não utilização de compartimento térmico para manter a temperatura necessária ao acondicionamento do produto.

e) Especificações procedimentais: contaminação bacteriana na bolsa de sangue em razão de inadequada manipulação ou limpeza dos equipamentos; falha humana no exercício das atividades; processo inadequado de produção; abertura do sistema de bolsas.

\subsubsection{DA LIBERAÇÃO DOS HEMOCOMPONENTES}

Para que haja o atendimento adequado das requisições de hemocomponentes, cada Serviço de Hemoterapia deverá estabelecer uma rotina de liberação/entrega das solicitações: seja por horário de atendimento, 
seja por vinculação dos hospitais, clínicas ou serviços atendidos, seja por priorização de gravidade e urgência de casos. As entregas de todos os hemocomponentes solicitados estarão sujeitas à disponibilidade do produto, em razão de sua escassez nos estoques do Serviço de Hemoterapia, que nesse caso, deverão fazer uma distribuição criteriosa e racional dos hemocomponentes, como foi dito anteriormente.

Usualmente esses hospitais e clínicas que são abastecidos por serviços de hemoterapia possuem um estoque em suas dependências para abastecê-los e os serviços de hemoterapia, por sua vez, fazem a reposição desses estoques que são estabelecidos em função do volume médio de pacientes atendidos, cirurgias realizadas, tipo de atendimento (com ou sem pronto-socorro, com ou sem traumas) etc. Ressaltando que nessas situações em que as instituições hospitalares fazem estoque existe uma dificuldade de se estabelecer uma rotina de análise das solicitações, tendo em vista que a situação de fornecimento existe apenas como uma expectativa de utilização e não como de aplicação/indicação em um caso/conduta.

Nesse sentido, o estabelecimento de Comitês Transfusionais nas instituições hospitalares poderia contribuir significativamente para a discussão das indicações clínicas de hemocomponentes e para estabelecimento dos critérios internos de uso e administração do sangue, o que resultaria em um estrito cumprimento das normas vigentes que impõem o uso racional e correto do sangue.

Os hemocomponentes liberados para uso devem receber um rótulo com as seguintes informações: temperatura de conservação; data e horário 
de vencimento; Grupo ABO e Fator Rh; resultado da pesquisa de anticorpos irregulares, se positivo, com o nome do anticorpo identificado; e a informação "resultado não-reagente para triagem de doenças infecciosas".

Caso os hemocomponentes tenham sido produzidos em "pool", a rotulagem deverá conter as informações: indicação de "pool" e número utilizado para produzir o "pool"; Grupo ABO e Fator Rh; volume aproximado; data e horário de vencimento; CMV negativo; instituição que preparou o “pool”.

Todas as anormalidades encontradas no processo, tais como, soroconversão, erro na triagem sorológica ou imunohematológica devem ser comunicadas à autoridade sanitária competente.

Os pontos críticos desta fase são:

a) Rotulagem: falha humana na transcrição de informações, na execução da atividade, na emissão de rótulos; troca de rótulos.

b) Falha humana na liberação dos hemocomponentes.

\subsubsection{DO PROCEDIMENTO TRANSFUSIONAL}

Essa é a segunda etapa da terapia transfusional. O médico, ao atender um paciente, entende que deveria ser indicada a transfusão de sangue diante de um determinado quadro clínico. O processo decisório de expor uma pessoa ao risco (porque é cediço que o procedimento transfusional é um processo, que mesmo sendo realizado com todas as cautelas, ainda corre o risco de contaminação residual - mensurável) deve ser baseado nas premissas: 1) quadro clínico do paciente; 2) indicações transfusionais; e 3) conhecimentos hemoterápicos para avaliar os riscos do 
procedimento, como também, as terapias e medicamentos alternativos à transfusão ${ }^{107-109}$.

A decisão de transfundir sangue deve ser baseada nos gatilhos transfusionais estabelecidos por instituições-referência como: American Association of Blood Bank $(\mathrm{AABB})^{110}$, International Society of Blood Transfusion (ISBT), Agência Nacional de Vigilância Sanitária (ANVISA) etc. ou pelos Comitês Transfusionais das Instituições Hospitalares que realizam transfusão de sangue.

Superado o processo decisório e concluída a pertinência da indicação transfusional, o médico fará as anotações no prontuário do paciente e preencherá a requisição de hemocomponentes, mencionando os dados do paciente (receptor), o tipo de hemocomponente solicitado, a quantidade solicitada, qual a doença que determinou a indicação do hemocomponente, se o hemocomponente deve apresentar alguma especificação (fenotipado, filtrado, irradiado, lavado, aliquotado etc.), se o paciente é politransfundido, se o paciente já apresentou alguma reação transfusional, bem como a gravidade/urgência para realização do procedimento que pode ser classificada em:

a) Programada: para determinado dia e hora.

b) Não urgente: a se realizar dentro de 24 horas.

c) Urgente: a se realizar dentro de 3 horas.

d) Extrema urgência: quando o retardo na administração da transfusão pode acarretar risco para a vida do paciente.

Esse é, sem dúvida, o momento mais importante da terapia transfusional. Ao considerarmos que a atividade é de risco, cabe ao médico 
que fez a indicação e prescrição transfusional, ponderar os ônus, os bônus do procedimento e dimensionar as possíveis reações irreversíveis e danosas próprias do processo ${ }^{111}$.

Nesta acepção, o ponto mais crítico desta etapa é a indicação equivocada de transfusão ${ }^{112,113}$, que pode ocorrer pelo despreparo técnico do médico em relação à terapia (imperícia); pela negligência dos riscos que são inerentes ao processo e pela imprudência de expor o paciente desnecessariamente ao risco, sendo que existem terapias alternativas tão eficazes e mais seguras do que a transfusão.

\subsubsection{DO CONSENTIMENTO INFORMADO}

Resolução $\mathrm{n}^{\circ}$ 1.246, de 8/1/1988, do Conselho Federal de Medicina (CFM) - Código de Ética Médica - prevê em seus artigos 46, 48, 56 e 59:

"É vedado ao médico: Art. 46 - Efetuar qualquer procedimento médico sem o esclarecimento e 0 consentimento prévios do paciente ou de seu responsável legal, salvo em iminente perigo de vida. Art. 48 - Exercer sua autoridade de maneira a limitar o direito do paciente de decidir livremente sobre a sua pessoa ou bem-estar. Art. 56 Desrespeitar o direito do paciente de decidir livremente sobre a execução de práticas diagnósticas ou terapêuticas, salvo em caso de iminente perigo de vida. Art. 59 - Deixar de informar ao paciente o diagnóstico, o prognóstico, os riscos e objetivos do tratamento, salvo quando a comunicação direta ao mesmo possa provocarIhe dano, devendo, nesse caso, a comunicação ser feita ao seu responsável legal."

Deste modo, como a transfusão é um procedimento médico, ela está sujeita ao esclarecimento quanto aos riscos e ao consentimento do paciente ${ }^{114}$. 
Neste momento, emerge um problema em relação ao consentimento para realização da transfusão sanguínea. Algumas confissões religiosas, como as Testemunhas de Jeová, proíbem a prática transfusional.

Essas confissões religiosas fundamentam juridicamente sua recusa na terapia transfusional com base no art. 5ำ III, da Constituição Federal (CF), que dispõe sobre a liberdade religiosa dos cidadãos brasileiros.

Essa não é uma questão pacífica na jurisprudência, como também na doutrina jurídica. Alguns juristas entendem que essa recusa colide com outros preceitos constitucionais, como o direito à vida e à dignidade da pessoa humana, previstos respectivamente nos arts. $1^{\circ}$ e $5^{\circ}$ caput da CF.

A discussão se baseia nas premissas: 1) de que o direito à vida é a hipótese material para o exercício dos demais direitos assegurados pela Constituição Federal, e, portanto, configura-se como precedente lógico do direito à liberdade religiosa; e, 2) que a recusa transfusional possui amparo na autonomia de vontade do paciente, que está ligado ao princípio da dignidade da pessoa humana.

Sobre essa questão, o Conselho Federal de Medicina promulgou Resolução CFM nำ 1021/80 para "adotar os fundamentos do parecer no processo CFM no 21/80, como interpretação autêntica dos dispositivos deontológicos referentes à recusa em permitir a transfusão de sangue, em casos de iminente perigo de vida", que em suma conclui:

"Em caso de haver recusa em permitir a transfusão de sangue, o médico, obedecendo seu código de ética, deverá obedecer a seguinte conduta:

$1^{0}$ - Se não houver iminente perigo de vida, 0 médico respeitará a vontade do paciente ou de seus responsáveis. 
$2^{0}$ - Se houver iminente perigo de vida, o médico praticará a transfusão de sangue independentemente do consentimento do paciente ou de seus responsáveis."

Em um caso específico, por exemplo, a Diretoria Executiva do Instituto Central do Hospital das Clínicas da Faculdade de Medicina da Universidade de São Paulo solicitou ao Comitê de Bioética (CoBi) da Instituição, um "Parecer quanto à manifestação de descontentamento dado ao cancelamento de cirurgia pela recusa de transfusão de sangue por motivos religiosos."

Sobre o assunto o CoBi proferiu o parecer $n^{\circ} 6 / 2005^{115}$, vejamos:

"Diálogo prévio antes da internação a fim de estabelecer a premissa de que haverá o compromisso de respeitar a recusa à transfusão de sangue até o limite do "iminente perigo de vida" que fique bem claro que a equipe médica repudia concordar em assistir a óbito por estrita carência de volume sanguíneo efetivo.

Este diálogo é possível, evidentemente, em situações eletivas; quando em emergência fica prejudicado, mas, a qualquer momento, deve ser provocado pela equipe médica, caso a situação assim o permita.

Caso haja necessidade de transferência de hospital, deve haver a preocupação da equipe de considerar não somente a que o paciente persiste sob sua responsabilidade até o destino, como também que tem o dever ético de confirmar com a equipe receptora se ela está inteirada exatamente das circunstâncias do caso.

Será lícito que a liberdade religiosa obrigue um médico a deixar que uma vida tenha fim? Não há nenhum valor jurídico estabelecido no sistema que obrigue o médico a praticar tais atos. Pelo contrário, não pode praticar tal omissão sob pena de cometer crimes tais como homicídio culposo e/ou omissão de socorro. A liberdade de profissão do médico pressupõe a utilização de todos os meios científicos disponíveis, inclusive a transfusão de sangue, cuja utilização não é mais uma novidade no meio médico. (...) No entanto, 
no sistema jurídico brasileiro, caberá sempre ao Poder Judiciário determinar o que for de direito.

Se iminente perigo de vida, é direito e dever do médico empregar todos os tratamentos, inclusive cirúrgicos, para salvar o paciente, mesmo contra a vontade deste, e de seus familiares e quem quer que seja, ainda que a oposição seja ditada por motivos religiosos. Pois conforme entendimento do Tribunal de Justiça do Estado de São Paulo 'conviccões religiosas não podem prevalecer perante o bem maior tutelado pela Constituição Federal é a vida." (grifos do autor)

Desta forma, entendemos que cabe à instituição hospitalar ou ao Serviço de Hemoterapia determinar qual conduta tomará diante desta situação, em estrita observância às normas vigentes.

\subsubsection{DA IDENTIFICAÇÃO DO RECEPTOR}

Um dos maiores problemas relacionados à transfusão de sangue ainda é o erro ocasionado pela infusão de sangue com incompatibilidade ABO.

Para evitar essa reação transfusional, instituições hospitalares do mundo todo buscam alternativas eficazes para melhorar a identificação dos pacientes. Pesquisas avaliaram que a realização de procedimentos por meio de código de barras é reconhecida como uma boa solução para identificação dos pacientes ${ }^{116}$. Outra solução eficiente é a introdução de rotinas de dupla ou tripla conferência do processo, que deve se iniciar desde o momento da coleta das amostras dos receptores até a infusão do hemocomponente.

No Brasil, a Comissão de Avaliação e Controle em Medicina Transfusional (CACTM), do Hospital das Clínicas da Faculdade de Medicina da Universidade de São Paulo (HCFMUSP), o maior hospital da América 
Latina, baseada em estudos da Joint Americana, estabeleceu que todos os procedimentos transfusionais realizados naquele hospital, inclusive a prescrição e a administração, deverão ser precedidos de checagem eletrônica, a ser realizada pelo corpo de enfermagem a partir do código de barras da pulseira do paciente ${ }^{69}$.

Quando esta fase do processo não possui mecanismos de controle e rechecagem, ela estará sujeita a erros, tais como, erro de transcrição de informações, erro na leitura de informação, ocorrência frequente de homônimos etc. Sendo que essas falhas podem ser decisivas para o acontecimento de uma reação transfusional por incompatibilidade sanguínea.

\subsubsection{DA SOLICITAÇÃO DE HEMOCOMPONENTES}

A RDC/MS nำ153/04 dispõe:

"I.1.1 - As solicitações para transfusão de sangue ou componentes devem ser feitas em formulários específicos que contenham informações suficientes para uma correta identificação do receptor. Do formulário devem constar, pelo menos, os seguintes dados: nome e sobrenome do paciente, sexo, idade, peso, número do registro do paciente, número do leito, diagnóstico, antecedentes transfusionais, hemocomponente solicitado (com o respectivo volume ou quantidade), tipo da transfusão, resultados laboratoriais que justifiquem indicação de hemocomponente, data, assinatura e número do CRM do médico solicitante. Uma requisição incompleta, inadequada ou ilegível não deve ser aceita pelo Serviço de Hemoterapia."

Preenchidas todas as informações necessárias com os dados corretos do doador, a solicitação de hemocomponente deverá ser 
classificada com fundamento na urgência da necessidade do procedimento, para tanto o item I.1.2 da RDC/MS nำ 153/04 prevê que as transfusões devem ser qualificadas como: a) programada, se ela está prevista para ser executada em determinado dia e hora; b) não urgente, se ela puder ser realizada dentro de 24 horas da solicitação; c) urgente, se ela tiver de ser realizada no prazo máximo de 3 horas da solicitação; ou d) de extrema urgência, quando o retardo na administração da transfusão poderá acarretar risco para à vida do paciente.

Caso o paciente seja politransfundido ou necessite de algum hemocomponente compatível com fenótipos de alta frequência com significância clínica, o médico deverá proceder da mesma maneira descrita anteriormente, solicitando o hemocomponente com fenótipo especificado.

Terminada a etapa de preenchimento da requisição, será procedida a coleta da amostra de sangue do paciente para realização dos exames prétransfusionais. Note-se que essa coleta pode ser feita por profissionais da instituição hospitalar ou do Serviço de Hemoterapia responsável pela transfusão, se for o caso, devendo o diretor clínico da instituição hospitalar ou o Comitê Transfusional (se houver) estabelecer a quem cabe cada uma das condutas.

Os pontos críticos desta fase são: a falha na identificação do receptor, bem como na transcrição de informações.

\subsubsection{DA COLETA DE AMOSTRA DO RECEPTOR}

Quando o médico que está tratando um paciente decide que a conduta correta a ser tomada é a transfusão de sangue, após a prescrição 
da indicação transfusional no prontuário do paciente, a equipe de enfermagem deverá coletar uma amostra de sangue do receptor para que sejam realizados testes pré-transfusionais, como veremos adiante.

Neste momento é muito importante que a identificação do paciente/receptor esteja correta para que não haja falhas na rotulagem do tubo de amostra de sangue do receptor, com vistas a evitar a transfusão de sangue incompatível. Esta amostra será responsável pela definição da tipagem sanguínea do paciente e pela liberação do hemocomponente compatível com ela.

A RDC/MS nำ153/04 (item I.3.4) determina que as amostras de sangue do receptor devem ser coletadas especificamente para realização dos testes pré-transfusionais.

A amostra de sangue para realização de exames pré-transfusionais tem a validade de 72 horas e deverá apresentar o volume de sangue de 5 $\mathrm{mL}$ para adultos e $1 \mathrm{~mL}$ para crianças. Com o propósito de evitar a ocorrência de falhas, a equipe de enfermagem deverá coletar amostra de sangue de um paciente por vez, checar os dados do paciente na etiqueta que deverá ser colada imediatamente ao tubo de amostra que o identificará como pertencente àquele paciente, identificar a data da coleta e o nome do profissional que realizou o procedimento e encaminhar a amostra e a requisição de transfusão de sangue à Agência Transfusional para preparação do pedido ${ }^{69}$.

Estudos demonstram que em cada seis transfusões incompatíveis, uma ocorre em razão da troca de amostra do receptor ${ }^{117}$. 
Os pontos críticos dessa etapa são: falha na rotulagem da amostra, troca de amostras, coleta inadequada de sangue etc.

\subsubsection{DO EXAME PRÉ-TRANSFUSIONAL}

A RDC/MS nำ153/04, no item a.4, determina que as instituições: a) que realizarem intervenções cirúrgicas de grande porte ou que efetuarem mais de 60 (sessenta) transfusões por mês devem contar com pelo menos uma Agência Transfusional nas suas instalações. Ao passo que em instituições que efetuarem menos de 60 (sessenta) transfusões por mês ou que realizarem atendimento de emergência, ou obstetrícia, ou cirurgias de médio porte podem ser supridas de sangue e componentes por Serviço de Hemoterapia externo, com contrato estabelecido de acordo com a resolução e prevendo o suprimento em caso de transfusão de extrema urgência.

Os exames pré-transfusionais são realizados para garantir a compatibilidade sanguínea do receptor/paciente com o hemocomponente a ser liberado para transfusão, visando evitar prejuízos à saúde do paciente.

Após a recepção e conferência da amostra e da requisição de transfusão sanguínea, a Agência Transfusional ou o Serviço de Hemoterapia iniciará a rotina de testagem que pode ser feita por meio das técnicas de tubo ou gel. A RDC/MS nำ 153/04 estabelece a realização de: a) retipificação $\mathrm{ABO}$ e Rh da bolsa de sangue; b) determinação do grupo $\mathrm{ABO}$, do fator $\mathrm{Rh}$ e a pesquisa de anticorpos irregulares no sangue do receptor; e, c) uma prova de compatibilidade entre as hemácias do doador e o soro do receptor (prova de compatibilidade maior). 
A retipagem $A B O$ da bolsa é feita com uma amostra de sangue retirada do tubo coletor da bolsa e a retipagem do fator $\mathrm{Rh}$ somente será executada em bolsas rotuladas como "Rh negativo".

Em seguida, é realizada a testagem da amostra do receptor para determinação do grupo $\mathrm{ABO}$ e do fator $\mathrm{Rh}$ e a pesquisa de anticorpos irregulares.

Para determinação do grupo $\mathrm{ABO}$, uma solução com hemácias do paciente diluída com soro fisiológico é adicionada aos reagentes Anti-A, Anti$B$ e Anti-AB. Sendo que se os reagentes forem monoclonais, a testagem AB não é obrigatória. Em seguida, é feita a tipagem reversa, com a adição de hemácias comerciais conhecidas (de mesma procedência dos outros reagentes) com o soro ou plasma do paciente.

A determinação do fator $\mathrm{Rh}$ dever ser feita com uma solução de hemácias do receptor diluídas com soro fisiológico acrescentadas ao soro anti-D, após centrifugação. Se houver aglutinação o resultado da testagem será positivo.

Finda a testagem $\mathrm{ABO}$, passa-se à fase de detecção dos anticorpos irregulares, que são os anticorpos encontrados no soro ou plasma do paciente. A amostra do soro ou plasma do receptor é acrescentada às hemácias comerciais do tipo "O" com fenotipagem conhecida para os mais importantes grupos sanguíneos. Essa solução deve ser incubada a $37^{\circ} \mathrm{C}$ por 30 minutos e posteriormente centrifugada, assim, se houver aglutinação, a amostra será considerada positiva para o fenótipo testado.

Para que seja atestada a compatibilidade do sangue do receptor com o hemocomponente que será disponibilizado para transfusão, deverá ser 
realizado um teste chamado prova cruzada maior. Para efetuar tal teste obtem-se uma amostra de hemácias retiradas do tubo coletor da bolsa a ser transfundida e, a estas hemácias se acrescenta soro ou plasma do paciente. Se houver aglutinação as amostras serão incompatíveis entre si e consequentemente não poderá haver a liberação do hemocomponente testado e o processo deverá ser reiniciado. Mas, se não houver aglutinação, a amostra e o hemocomponente são compatíveis e a bolsa de hemocomponente poderá ser liberada para uso.

Entretanto, se não houver disponibilidade de sangue compatível com o do paciente no Serviço de Hemoterapia, o médico que solicitou a transfusão deverá reavaliar o caso em conjunto com o serviço.

Caso seja feita a opção de se transfundir sangue incompatível, esta decisão deverá ser justificada por escrito, em termo que deve ser assinado pelo hemoterapeuta, pelo médico-assistente do paciente e, quando possível, pelo próprio paciente ou por seu responsável legal, conforme dispõe a $\mathrm{RDC} / \mathrm{MS} \mathrm{n}^{\circ}$ 153/04.

Cabe dizer que a prova cruzada deve ser realizada antes da liberação de hemocomponentes para transfusão, com exceção das solicitações de extrema urgência. Neste caso, o Serviço de Hemoterapia ou a Agência Transfusional deverá liberar o hemocomponente com a assinatura de compromisso do médico solicitante e do médico hemoterapeuta e, após a liberação da urgência, os serviços de hemoterapia deverão proceder às rotinas de testagens completas das amostras de sangue do receptor e da bolsa liberada para uso. 


\subsubsection{DA LIBERAÇÃO DO HEMOCOMPONENTE PARA TRANSFUSÃO}

Após a realização dos testes pré-transfusionais, o hemocomponente adequado deverá ser liberado para uso. Por hemocomponente adequado entende-se: componente sanguíneo solicitado, isogrupo ou com compatibilidade $\mathrm{ABO}$ e fator Rh, e, se necessário compatível com fenótipos de significância clínica e procedimentos (irradiado, lavado, filtrado, aliquotado etc.).

O hemocomponente deve ser liberado com uma etiqueta afixada ao produto que contenha nome completo do paciente, localização de internação, leito, grupo sanguíneo $\mathrm{ABO}$ e fator $\mathrm{Rh}$ do paciente, número de identificação da unidade do hemocomponente, resultado da prova cruzada maior e data do envio do hemocomponente para transfusão. Dessa maneira, o hemocomponente estará disponível para ser transportado até o leito do paciente. O transporte do hemocomponente liberado poderá ser feito pela equipe de enfermagem da instituição hospitalar ou pela equipe do Serviço de Hemoterapia. A responsabilidade por essa fase do processo deverá ser estipulada pelo diretor clínico da instituição hospitalar e/ou se houver, pelo Comitê Transfusional da entidade. Vale dizer que a RDC/MS no 153/04 determina que: a) os componentes eritrocitários podem permanecer somente 30 minutos em temperatura ambiente; b) os componentes plasmáticos podem permanecer até 6 horas após seu descongelamento em temperatura entre $22^{\circ} \mathrm{C} \pm 2^{\circ} \mathrm{C}$, e 24 horas entre $4^{\circ} \mathrm{C} \pm 2^{\circ} \mathrm{C}$; e, c) os componentes plaquetários devem ser transfundidos em até 24 horas após serem retirados dos agitadores $^{118}$. 
Os pontos críticos da etapa de liberação dos hemocomponentes para uso são: a troca de hemocomponentes; falha no preenchimento ou transcrição de informações; falha na afixação da etiqueta de identificação do receptor; retardo no transportes até o leito, conforme tempo e temperatura acima indicados.

\subsubsection{DA INFUSÃO DO HEMOCOMPONENTE}

A RDC/MS nำ153/04 prevê que a infusão de sangue ou componente deve ser realizada por médico ou profissional de saúde habilitado, qualificado e conhecedor das normas que regem a atividade hemoterápica, desde que sejam supervisionadas por um médico que possa intervir em casos de reações ou complicações.

A norma ainda impõe que deve ser feita a aferição dos sinais vitais do paciente antes de se iniciar a transfusão, sendo que essas informações devem ser anotadas no prontuário dele.

Antes da infusão do hemocomponente, a equipe de enfermagem deverá checar a identidade do paciente, perguntando-lhe (ou a seu acompanhante) seu nome completo para certificar-se de que é a mesma identificação contida na bolsa de sangue que será infundida. Nesse momento, se houver qualquer conflito de informações a transfusão não deverá ser instalada.

O procedimento transfusional deve ser feito com materiais apirogênicos, descartáveis e com filtro-padrão para conter coágulos e agregados. Quando se utilizar filtros para leucorredução ("bed side") não é preciso utilizar o filtro padrão. Ressalta-se que a RDC/MS nำ153/04 veda a 
administração de qualquer medicamento adicionado à bolsa ou em paralelo (na mesma linha venosa), excetuando-se, em casos excepcionais, a solução de cloreto do sódio a $0,9 \%$, onde deverá ser coletada uma nova amostra de sangue do paciente que deverá ser encaminhada para a realização dos testes pré-transfusionais para que haja a tentativa de identificação do erro cometido.

A infusão dos componentes sanguíneos deverá ser feita em até quatro horas. Caso esse tempo seja ultrapassado o procedimento deve ser interrompido e a bolsa descartada.

A RDC/ MS no 153/04 impõe que os primeiros dez minutos de transfusão sejam acompanhados por um profissional de saúde ou médico qualificado, que deverá permanecer ao lado do paciente durante esse período.

Passado esse período, a infusão poderá ser acompanhada periodicamente pela equipe de enfermagem, a fim de possibilitar a detecção precoce de eventuais reações adversas no paciente.

Caso o profissional de saúde que estiver acompanhando a realização do procedimento identificar alguma reação adversa no paciente, ele deverá interromper a transfusão e chamar imediatamente o médico para avaliar os sinais e sintomas.

A Resolução nº 200 do Conselho Federal de Enfermagem (COFEN), que regula a conduta de atuação dos profissionais de enfermagem em hemoterapia e transplante de medula, diz, no item 4 intitulado "Competência do Enfermeiro em Hemoterapia" que: 
“n) Elaborar a prescrição de enfermagem, necessária para as diversas etapas do processo hemoterápico.

o) Avaliar e evoluir doador e receptor, junto, à equipe multiprofissional.

p) Executar e/ou supervisionar a administração e a monitorização da infusão de hemocomponentes e hemoderivados, detectando as eventuais reações adversas.

r) Manejar e monitorizar equipamentos específicos de hemoterapia”.

Com a transcrição das alíneas anteriores, verificamos que o enfermeiro pode efetuar a infusão do componente e acompanhar o procedimento até a transfusão da última gota de sangue. Contudo, a conduta do corpo de enfermagem bem treinado e capacitado é crucial para o adequado transcurso da transfusão, bem como para a identificação de possíveis reações transfusionais.

Vale dizer que as transfusões ambulatoriais devem ser realizadas em locais apropriados e desde que sejam observadas as mesmas regras das transfusões em pacientes internados. Por outro lado, transfusões domiciliares podem ocorrer, desde que haja contra indicação formal para o translado do paciente até uma instituição hospitalar, porém o procedimento transfusional deverá ser inteiramente supervisionado por um médico que deverá possuir todos os equipamentos de retaguarda necessários à execução do procedimento.

Os pontos críticos desta fase são: troca de hemocomponentes; falha na administração e acompanhamento da infusão dos hemocomponentes; falha na identificação de reações transfusionais; demora para solicitar a avaliação médica do caso; falha na realização do exame prévio de aferição 
dos sinais vitais antes da transfusão; não anotação dos dados no prontuário do paciente etc.

\subsubsection{DAS REAÇÕES TRANSFUSIONAIS}

As reações são complicações ou efeitos de uma determinada ação. Do procedimento transfusional podem ocorrer reações classificadas como agudas ou tardias. Algumas podem ter origem em alguma falha do processo e outras podem ser devidas à reação do organismo, que embora seja previsível, não pode ser evitada durante o procedimento.

As reações transfusionais agudas são as que ocorrem durante a transfusão ou em até 24 horas, contadas do início do procedimento. As reações transfusionais tardias são aquelas que ocorrem após 24 horas da realização da transfusão.

As reações transfusionais agudas são subdivididas em imunes (originárias de reação imunológica do organismo) ou não-imunes ${ }^{69}$.

As reações transfusionais agudas imunes são: reação febril não hemolítica; reação hemolítica imune; reação alérgica: leve, moderada e grave; TRALI ( Transfusion related acute lung injury) - injúria pulmonar aguda relacionada à transfusão.

As reações transfusionais agudas não-imunes são: contaminação bacteriana; alterações eletrolíticas; sobrecarga de volume; hemólise nãoimune; embolia gasosa; hipotermia; hipocalcemia.

As reações transfusionais tardias são: aloimunização eritrocitária e HLA; reação enxerto versus hospedeiro relacionada à transfusão (GVHD- 
TA); imunomodulação; púrpura pós-transfusional; hemossiderose e transmissão de doenças infecciosas.

Por conseguinte, é de extrema importância que os profissionais da área de saúde estejam aptos a identificar corretamente as reações transfusionais, para que se possam adotar, o mais brevemente, processos de tratamento e reversão quando possíveis, a fim de não causarem prejuízos à saúde do paciente ${ }^{3}$. 


\subsection{DA BIOÉTICA E DO DIREITO}

O levantamento histórico da atividade hemoterápica feito no início deste trabalho serve-nos de alicerce para a justificação lógica da normatização existente.

Com o desenvolvimento tecnológico da medicina, a hemoterapia passou de empírica para científica e, ao analisarmos a evolução da atividade, percebemos que as experimentações passadas, a modernidade tecnológica, os resultados prejudiciais ou benéficos do processo, o melhor domínio da técnica etc., resultaram em um expressivo esforço da Organização Mundial de Saúde desde 1969 em padronizar a hemoterapia.

Note-se que o empenho da Organização Mundial de Saúde refletia um novo comportamento da sociedade que, desde as barbáries cometidas contra os prisioneiros nos campos de concentração nazista ocorridas durante a $2^{\underline{a}}$ Guerra Mundial para a realização de pesquisas clínicas com seres humanos, passou a ponderar questões éticas, filosóficas e morais em detrimento dos avanços da ciência.

Essa eclosão de novos valores sociais decorreu da modificação da promulgação do Código de Nuremberg em 1947, da Declaração Universal dos Direitos Humanos em 1948, da Declaração de Helsinque em 1964 e do Acordo Internacional sobre direitos civis e políticos em 1966, que fizeram emergir os direitos individuais dos cidadãos, especialmente os de valorização e respeito à dignidade da pessoa humana.

Nesse sentido, DINIZ conclui: 
"A necessidade de um padrão moral que possa ser compartilhado por pessoas de moralidades diferentes, pois se há constatação mundial de inversão de valores morais, de apatia $e$ fragmentação moral, em razão do caráter pluralista da sociedade moderna. Por isso Engelhardt considera ser um grande desafio à moral contemporânea o estabelecimento de questões oriundas do progresso das ciências biomédicas e da tecnologia científica aplicadas à saúde"119.

Deste modo, a ética tal como ciência normativa dos comportamentos humanos $^{120}$ foi um fator importante para o desenvolvimento da medicina em harmonia com os interesses individuais e sociais da coletividade.

A palavra "bioética" (ética da vida) foi mencionada publicamente pela primeira vez em um artigo chamado "Bioethics, the science of survival", escrito em 1970 pelo oncologista americano Van Rensselaer Potter. Esse artigo fazia parte do seu livro intitulado "Bioethics: bridge to the future", que discutia a controvérsia dos avanços científicos alcançados pelos cientistas em contraponto à manutenção da saúde e do bem-estar das pessoas.

Em sua obra, Potter se mostrava preocupado com o rápido progresso científico, com o anacronismo dos questionamentos necessários para suas execuções e protestava pela criação de uma nova ciência baseada na união dos conhecimentos biológicos (bio) e dos valores humanos (ética). Para ele, a atual inquietação dessa geração em relação à sobrevivência ocorre em razão da separação existente entre a cultura científica e a cultura clássica (as humanidades), que evoluíram separadamente, sem se influenciarem reciprocamente. Por tudo isso, somente a junção dessas duas culturas será 
responsável por instituir uma nova maneira de pensar responsável por estabelecer uma ponte rumo ao futuro ${ }^{121}$.

Os ensinamentos de REALE (1995) complementam:

“(..) graças às ciências culturais, é nos possível reconhecer que, em virtude do incessante $e$ multifário processo histórico, o gênero humano veio adquirindo consciência da irrenunciabilidade de determinados valores considerados universais e, como tais atribuíveis a cada um de nós. Correspondem eles, ao que denominamos invariantes axiológicas ou valorativas, como as relativas à dignidade da pessoa humana, à salvaguarda da vida individual e coletiva, elevando-se até uma visão planetária em termos ecológicos"122.

REALE (1995) ainda diz que entre as finalidades do Direito estão a salvaguarda e a segurança dos valores supremos (dignidade da pessoa humana, vida etc.), assim como dos que deles decorrem e "sem os quais não caberia falar em liberdade, igualdade e fraternidade - o que demonstra que a experiência jurídica é uma experiência ética"122.

Segundo HIRONAKA (2001):

"O papel do Direito não é o de cercear o desenvolvimento científico, mas justamente o de traçar aquelas exigências mínimas que assegurem a compatibilização entre os avanços biomédicos que importam na ruptura de certos paradigmas e a continuidade do reconhecimento da Humanidade enquanto tal, e, como tal, portadora de um quadro de valores que devem ser assegurados e respeitados ${ }^{\prime 123}$.

Portanto, a bioética como ciência pluridisciplinar ${ }^{123}$ representa a interconexão entre a medicina e o Direito. França, ao conceituar a medicina, diz: 
"A medicina é tão antiga quanto a dor e seu humanismo, tão velho quanto a piedade humana. Tem como finalidade precípua a investigação das mais diversas entidades nosológicas, e estabelecer condutas terapêuticas, no sentido de manter ou restituir a saúde dos indivíduos. É também missão dessa ciência orientar $e$ esclarecer os legisladores na elaboração das leis sobre os fatos médicos e fomentar 0 bem social"124.

Ao explicar a teoria tridimensional do direito REALE (1995) completa:

"Um análise em profundidade dos diversos sentidos da palavra Direito veio demonstrar que eles correspondem a três aspectos básicos, discerníveis em todo e qualquer momento da vida jurídica: um aspecto normativo (o Direito como ordenamento e sua respectiva ciência); um aspecto fático (o Direito como fato, ou em sua efetividade social e histórica) e um aspecto axiológico (o Direito como valor de Justiça)"125.

No caso da correlação entre a medicina e o Direito, este último será um balizador de condutas e garantidor de direitos e deveres em busca da paz social que é seu objetivo primordial.

\subsection{DA COMPATIBILIZAÇÃO ENTRE O DIREITO E A HEMOTERAPIA}

Fazer a correlação do exercício de um procedimento técnico com os fundamentos legais pertinentes não é uma tarefa fácil, porque o nível de especialidade do assunto inibe a manifestação de pessoas que não são aprofundadas no tema, como já dizia Perlingieri (2002):

"Da confrontação fato-norma pode-se individualizar o valor idôneo para ser reservado àquele fato concreto e o ordenamento assume um significado real sem perder a sua intrínseca função de "ordenar". Fato e norma - não já as palavras que os descrevem - são o objeto do conhecimento do jurista destinado a passar do particular ao particular, reduzindo tudo à unidade 
dos valores jurídicos sobre os quais se funda a convivência social e a justiça dos casos individuais.

Difícil é a individualização dos corolários de tal concepção. É necessário, em especial, uma teoria de interpretação que, superando as contraposições entre a fattispecie abstrata e a fattispecie concreta, procure dar a máxima valorização das peculiaridades do fato - não através de um procedimento mecânico de subsunção em rígidos e não completamente correspondentes esquemas legislativos, mas procurando, em respeito ao seu significado subjetivo, a normativa que seja mais compatível com os interesses e os valores em jogo segundo a hierarquia que compõe o ordenamento. A normativa deve ser individuada (sic.) levando em consideração, em conformidade com o critério de justiça reconhecido pelo ordenamento, todas as circunstancias atenuantes e agravantes do caso, de maneira a proporcionar (relativizzare) a decisão (com o caso) sem atentar ao princípio da igualdade. Trata-se de avaliar o fato analisando-o naquelas que poderiam parecer condições ou modalidades marginais e acessórias, de individuar a normativa do caso concreto à luz das normas e dos princípios, procurando no âmbito do ordenamento a disciplina "compatível" com aquele determinado regulamento de interesses"126.

Por essa razão, a descrição das fases do processo feita anteriormente neste trabalho teve por objetivo colaborar com o desenvolvimento lógico da correlação que buscamos.

O início do raciocínio a ser seguido é que todo médico deve primar pelo melhor exercício de sua profissão, não expondo o paciente desnecessariamente ao risco - sempre sopesando os riscos em face dos benefícios antes de optar por um determinado tratamento, não executando procedimentos para os quais ele não esteja habilitado a desempenhar ou que desconheça a forma de realização ${ }^{127}$. 
Quando o médico, por exemplo, realiza suas atividades sem a devida observância das condutas-padrões a serem seguidas (negligência), e/ou sem possuir capacitação para desempenhá-las (imperícia), e/ou expõe o paciente desnecessariamente ao risco (imprudência) existirá uma significante propensão de que essa conduta cause danos ao paciente.

Contudo, durante o exercício das atividades médicas, mesmo que todos os cuidados sejam criteriosamente observados, pode haver alguma reação adversa originária dessa ação médica, que também pode decorrer em prejuízos ao paciente, posto que a ciência médica não é exata.

Quando algum fato danoso acontece dizemos que houve um fato juridicamente relevante, porque não importa se o ato é lícito ou ilícito, se ele teve ou não repercussões jurídicas sempre haverá no Direito uma maneira positivada ou implícita de enquadramento e valoração diante das normas vigentes $^{128}$. Logicamente que o exercício da atividade médica em estrita obediência aos padrões e normas existentes excluirá a punibilidade em relação ao médico que realizou o procedimento, inclusive a lei brasileira vigente prevê essas excepcionalidades.

"Todo fato juridicamente relevante e, em particular, todo fato humano voluntário, todo ato de iniciativa privada têm uma função, a qual ou é predeterminada pelo ordenamento nos esquemas típicos, ou é modelada pela iniciativa dos sujeitos. A função, portanto, é a síntese causal do fato, a sua profunda e complexa razão justificadora: ela refere-se não somente à vontade dos sujeitos que o realizam, mas ao fato em si enquanto social e juridicamente relevante. A razão justificadora é ao mesmo tempo normativa, econômica, social política e por vezes também psicológica (assim é, por exemplo, em muitos atos familiares com conteúdo não patrimonial)"129. 
O enquadramento do fato à norma segue um esquema legal que é chamado de hierarquia das normas, que Perlingieri (2002) define esse assunto com precisão:

"A hierarquia das fontes não responde apenas a uma expressão de certeza formal do ordenamento para resolver os conflitos entre as normas emanadas por diversas fontes; é inspirada, sobretudo, em uma lógica substancial, isto é, nos valores e na conformidade com a filosofia de vida presente no modelo constitucional. O respeito à Constituição, fonte suprema, implica não somente a observância de certos procedimentos para emanar a norma (infraconstitucional), mas também, a necessidade de que o seu conteúdo atenda aos valores presentes (e organizados) na própria Constituição"130.

Ele deve ser enquadrado às normas vigentes a partir da Constituição Federal, que é a norma suprema do nosso ordenamento jurídico.

Ao aplicarmos essas premissas ao caso em tela, ou seja, à atividade hemoterápica, partimos do pressuposto de que toda atividade médica existe em benefício da saúde das pessoas. Assim sendo, devemos buscar a correspondente tutela no ordenamento jurídico a partir da Constituição Federal.

A Constituição Federal Brasileira vigente, seguindo a tendência de evolução social já consagrada há algum tempo nas Constituições de outros países como a França, Itália, Portugal e Estados Unidos, passou a reconhecer o princípio da dignidade da pessoa humana como um dos baldrames fundamentais do Estado Democrático de Direito (art. 1ํ, III $\mathrm{CF}^{131}$ ); dessa forma as pessoas passaram a ser "sujeito e ponto de referência objetivo" de toda proteção jurídica ${ }^{132}$, diferentemente do que acontecia até 
então, quando a preocupação de amparo estava voltada aos direitos da propriedade.

Essa mudança de paradigma, que alçou o princípio da dignidade da pessoa humana como pedra angular do direito, trouxe a primazia dos interesses individuais sociais e permitiu que seus corolários, tal como a integridade psicofísica ${ }^{133}$, pudessem ser ajustados à situação fática e à proteção do ordenamento tal como a bioética perquiria ${ }^{134}$.

Moraes, A. (2000) define o conceito de dignidade da pessoa humana:

"Dignidade da pessoa humana: concede unidade aos direitos e garantias fundamentais, sendo inerente às personalidades humanas. Esse fundamento afasta a idéia de predomínio das concepções transpessoalistas de Estado e Nação, em detrimento da liberdade individual. $A$ dignidade é um valor espiritual e moral inerente à pessoa, que se manifesta singularmente na autodeterminação consciente e responsável da própria vida e que traz consigo a pretensão ao respeito por parte das demais pessoas, constituindo-se um mínimo invulnerável que todo estatuto deve assegurar, de modo que, somente excepcionalmente, possam ser feitas limitações ao exercício dos direitos fundamentais, mas sempre sem menosprezar a necessária estima que merecem todas as pessoas enquanto seres humanos"135.

A evolução baseada no respeito à dignidade humana que havia sido defendida por Immanuel Kant como fundamento do imperativo categórico, não se limitou somente à Lei Maior, o Direito Civil também foi alcançado, especialmente a matéria de responsabilidade civil, "a qual acabou por se revelar a forma mais fácil e justa, até hoje, de tutelar a dignidade, isto é, a integridade psicofísica, a igualdade, a solidariedade e a liberdade humana"136. A questão é muito bem exposta por Bodin de Moraes (2006): 
"O princípio constitucional visa garantir o respeito e a proteção da dignidade humana não apenas no sentido de assegurar um tratamento humano $e$ não degradante, e tampouco conduz ao mero oferecimento de garantias à integridade física do ser humano. Dado o caráter normativo dos princípios constitucionais, princípios que contêm os valores ético-jurídicos fornecidos pela democracia, isto vem a significar a completa transformação do direito civil, de um direito que não mais encontra nos valores individualistas ou de outrora o seu fundamento axiológico.

Neste ambiente, de um renovado humanismo, a vulnerabilidade humana será tutelada, prioritariamente, onde quer que ela se manifeste. De modo que terão precedência os direitos e as prerrogativas de determinados grupos considerados, de uma maneira ou de outra, frágeis e que estão a exigir, por conseguinte, a especial proteção da lei, ${ }^{\text {i37. }}$.

Vê-se, pois, que a Constituição Federal não cria um direito às pessoas humanas, primeiramente ela as salvaguarda (art. 1ํㅡ, I e II CF) e por consequência, elas passam a ter direitos (art. $5^{\circ} \mathrm{CF}$ ), inclusive, ao de reparação no caso de ofensa a sua dignidade (integridade psicofísica, igualdade, solidariedade e liberdade humana).

A proteção constitucional acabou por erigir uma cláusula geral de tutela da pessoa humana, evidenciada pela interpretação correlacionada dos fundamentos (art. 1ํㅡ. I e II CF), dos objetivos (art. $3^{\circ}$, III CF) e dos direitos e garantias constitucionais (art. 5) das pessoas humanas, e que deve ser utilizada para o desenvolvimento dialético de subsunção do fato à norma.

Destarte, como "o alvo de toda atenção do médico é a saúde do ser humano e em benefício da qual deverá agir com o máximo de zelo e o melhor de sua capacidade profissional"138, não podemos deixar de concluir que toda ação médica culposa ativa ou omissiva que causar dano às 
pessoas vai se enquadrar na ofensa da cláusula geral de tutela da pessoa humana, que segundo Perligieri (2002) não se refere apenas aos direitos individuais de um determinado sujeito para seu único e exclusivo interesse, mas diz respeito aos direitos individuais sociais que são orientados pelo princípio da solidariedade ${ }^{139}$.

Assim como o desenvolvimento do raciocínio inicial de ajustamento do fato às normas vigentes, respeitando-se a hierarquia do ordenamento, podemos concluir que toda conduta (médica ou não) dolosa ou culposa vai se enquadrar na cláusula geral de tutela da pessoa humana, mas existem outras previsões constitucionais que também se alinham a essa problemática.

Entre os direitos individuais e coletivos das pessoas consubstanciados na cláusula geral de tutela da pessoa humana também está contido o direito à vida, previsto no caput do art. $5^{\circ} \mathrm{CF}$, que ao nos referirmos às atividades médicas acabam por nos remeter a outra proteção legal constitucional, que é o direito à saúde (art. 196 CF). Ele está normatizado como "um direito do cidadão e um dever do Estado garantido mediante políticas sociais e econômicas que visem à redução do risco de doença e de outros agravos e ao acesso universal e igualitário às ações e serviços para sua promoção, proteção e recuperação"131.

Mas o que é saúde?

"É uma condição em que um indivíduo ou grupo de indivíduos é capaz de realizar suas aspirações, satisfazer suas necessidades e mudar ou enfrentar o ambiente. A saúde é um recurso para a vida diária, e não um objetivo de vida; é um conceito positivo, enfatizando recursos sociais $e$ pessoais, tanto quanto as aptidões físicas. É um 
estado caracterizado pela integridade anatômica, fisiológica e psicológica; pela capacidade de desempenhar pessoalmente funções familiares, profissionais e sociais; pela habilidade para tratar com tensões físicas, biológicas, psicológicas ou sociais com um sentimento de bem-estar e livre do risco de doença ou morte extemporânea. É um estado de equilíbrio entre os seres humanos e o meio físico, biológico e social, compatível com plena atividade funcional"140.

Em complementação, o art. 197 da CF diz ainda que "são de relevância pública as ações e serviços de saúde, cabendo ao Poder Público dispor, nos termos da lei, sobre sua regulamentação, fiscalização e controle, devendo sua execução ser feita diretamente ou através de terceiros e, também, por pessoa física ou jurídica de direito privado"131.

Neste diapasão BURITY (1982) acrescenta:

"A vida, a integridade corporal, a honra e a liberdade são bens supremos da pessoa humana, cuja eficiente proteção se faz dever precípuo do Estado, na sua ação de preservar as condições básicas de perpetração da espécie e de manter a ordem e a tranqüilidade indispensáveis à sobrevivência das comunidades"141.

A integridade psicofísica do indivíduo (corolário do princípio da dignidade da pessoa humana) é um dos aspectos que definem o conceito de saúde. Contudo, como a hemoterapia é uma terapêutica que tem por objetivo a melhora ou a manutenção da saúde, consideramos que esses preceitos são basilares para a formação do pensamento dialético de conexão entre o direito e a hemoterapia.

Cumpre ressaltar que a República Federativa Brasileira é um Estado Democrático de Direito (art.1 ${ }^{\circ} \mathrm{CF}$ ) e isso pressupõe a rigorosa sujeição de todos os cidadãos ao sistema jurídico vigente no país, portanto, conforme 
previsão do inciso II do artigo $5^{\circ}$ da Constituição Federal ${ }^{131}$ : "ninguém será obrigado a fazer ou a deixar de fazer alguma coisa senão em virtude de lei".

\subsection{DA REGULAMENTAÇÃO DA HEMOTERAPIA}

Para França (1982), "o direito médico deve compreender um conjunto de normas necessário numa sociedade organizada, referentes à pessoa e à atividade médica, e impostas coativamente pelo Poder Público, disciplinando não apenas a profissão, mas também tudo aquilo a que estão obrigadas as pessoas ante a Medicina"142.

A tutela legal em relação ao sangue, matéria-prima da hemoterapia, está prevista na Lei Maior que prevê em seu $\S 4^{0}$ do art. 199 CF:

"A lei disporá sobre as condições e os requisitos que facilitem a remoção de órgãos, tecidos e substâncias humanas para fins de transplante, pesquisa e tratamento, bem como a coleta, processamento e transfusão de sangue e seus derivados, sendo vedado todo tipo de comercialização".

Somente treze anos após a promulgação da Constituição de 1988, o legislador publicou a Lei $n^{0} 10.205 / 2001^{143}$, que regulamentou o parágrafo supracitado e estabeleceu o ordenamento indispensável à execução adequada da atividade hemoterápica. Sete meses após a promulgação dessa lei foi publicado o Decreto $n^{\circ} 3.990 / 2001^{144}$ para regulamentá-la, porém, durante todo esse lapso temporal até os dias atuais, a forma de produção e execução, bem como os princípios gerais da especialidade, foram detalhadamente normatizados em Portarias e Resoluções do Ministério da Saúde.

O parágrafo primeiro do art. $3^{\circ}$ da Lei $n^{\circ} 10.205 / 2001$ prevê: 
"A hemoterapia é uma especialidade médica, estruturada e subsidiária de diversas ações médico-sanitárias corretivas e preventivas de agravo ao bem-estar individual e coletivo, integrando, indissoluvelmente, o processo de assistência à saúde.

A Lei no $10.205 / 2001$ enfatiza ainda que os serviços de hemoterapia em funcionamento ou os que virão a funcionar deverão obedecer as demais leis sanitárias vigentes do Ministério da Saúde e receber anualmente uma autorização de funcionamento do Órgão de Vigilância Sanitária de cada nível de governo ( $\left(2^{\circ}\right.$ do art. $\left.3^{\circ}\right)$. Sendo que as atividades executadas pelos serviços de hemoterapia devem estar sob responsabilidade de um médico hemoterapeuta ou hematologista, admitindo-se, no entanto, nos locais onde não haja esses especialistas, sua substituição por outro médico devidamente capacitado para execução da hemoterapia (art. $7^{0}$ ).

Contudo, o procedimento hemoterápico é uma das poucas práticas médicas regidas por lei. Assim sendo, a adequada observância das normas procedimentais vigentes no exercício da atividade é imperativa, coercível e não pode ser descumprida pelo médico sob a alegação de desconhecimento (art. 6ํำ da Lei de introdução ao Código Civil).

Neste diapasão, vale dizer que a infringência das normas existentes, além de configurar infração às normas técnicas específicas, também pode caracterizar descumprimento das disposições sanitárias vigentes e se enquadrar nas sanções previstas na Lei $n^{\circ} 6.437 / 77^{145}$. 


\subsection{DA CONCEITUAÇÃO DA ATIVIDADE}

Para o adequado deslinde da argumentação, tornam-se indispensáveis as lições de Hironaka (2005) ${ }^{146}$ :

"A ausência de inteiração da área do saber provocou, consequentemente, o fracionamento do próprio pensamento, bem como, do próprio conhecimento transplantado - como não poderia ter deixado de acontecer - este viés picotado também para a pesquisa e para o ensino, infelizmente. De consequência em consequência, e como produto final, esse processo de parcelamento acabou por produzir profissionalização igualmente especializada, distante do padrão contemporaneamente da globalização ou da mundialização.

O reclamo por um retorno e por uma maior integração entre os saberes reflete-se por todo complexo das inter-relações humanas $e$ transforma a própria sociedade, que solicita uma superação deste exagerado modelo de racionalidade científica e uma nova mente - entre nós -, nos espaços destinados a uma construção normativa tal que possa atender os anseios do homem de hoje e de sua circunstância valorativa renovada.

O direito, assim, e de resto como todos os demais saberes da contextualização geral do conhecimento, necessita de troca de experiências para reescrever seus meios e modos de alcançar, com sucesso, a sua própria finalidade: a construção de uma sociedade, livre, justa e solidária, conforme perspectiva constitucional fundamental, para atingir o objetivo essencial da Humanidade, isto é, a produção de uma vida digna em prol da conquista da paz social."

A Organização Mundial da Saúde (OMS) ressalta a importância da transfusão de sangue como método terapêutico, porém reconhece os riscos inerentes à atividade:

"Blood transfusion is an essential part of patient care. When used correctly, it saves lives and 
improves health. However, blood transfusion carries a potential risk acute or delayed complications and transfusion-transmitted infections and should be prescribed only to treat conditions associated with significant morbidity or mortality that cannot be prevented or managed effectively by other means" $^{147}$. (Grifos nossos)

Como dissemos anteriormente, a norma reguladora da atividade hemoterápica vigente no país é a RDC/MS nํ153/04 que no mesmo sentido da OMS afirma:

"A. 1 - Toda transfusão de sangue traz em si um risco, seja imediato ou tardio, devendo, portanto, ser criteriosamente indicada."

"A. 9 - A transfusão de sangue e componentes deve ser utilizada criteriosamente, tendo em conta que é um procedimento que não está isento de riscos. Sua indicação poderá ser objeto de análise pelo serviço de hemoterapia."

Chamone et al. (2001) ${ }^{148}$ concluem: "A apropriada indicação do uso do sangue e de seus componentes também é importante para minimizar o perigo de transmissão das viroses. Deve-se ter em conta que, mesmo com os avanços da medicina transfusional, o sangue não é $100 \%$ seguro em nenhum país".

Por todo o exposto, é notório o reconhecimento de que a transfusão de sangue é um procedimento de risco. Essa classificação insere o fato (transfusão de sangue) numa esfera de previsibilidade de dano, que não significa defeito do produto, falha na sua produção ou, ainda, na prestação do serviço. 
O risco é intrínseco à atividade - transfusão de sangue, mesmo que sejam utilizadas todas as tecnologias existentes e disponíveis no processo de produção, ainda assim remanescerá a possibilidade de contaminação por doenças transmissíveis, em razão do risco residual (janela imunológica, mutação viral, doenças emergentes etc.).

Porém, há que se considerar que a transfusão de sangue é uma terapia médica, uma forma de tratar o paciente. Dias $(2006)^{149}$ tece algumas considerações sobre a visão jurídica do tratamento médico:

"Tratamento é, em medicina e artes similares, a soma dos meios empregados para conservar a vida, melhorar a saúde ou aliviar a dor. É no tratamento, naturalmente, que ocorrem os casos mais numerosos de responsabilidade, por ser mais larga a oportunidade do exercício da medicina aos erros e procedimentos contrários às regras da profissão. Concederam fatos reveladores de erro ou culpa e, portanto, capazes de acarretar a responsabilidade do médico: a) o de expor o doente a riscos que podiam ser evitados como inúteis ou indispensáveis para o restabelecimento."

Em relação à contaminação por doenças infecciosas por transfusão de sangue a probabilidade de dano do procedimento, especificamente do risco residual atual de contaminação pelo vírus HIV, em São Paulo é de uma contaminação a cada 60.000 transfusões realizadas. Como padrão comparativo, na era Pré-NAT, em países desenvolvidos como a Itália, o risco de contaminação residual para HIV nas transfusões era de uma contaminação para 524.000 transfusões realizadas; no Canadá uma contaminação para 10.000.000 transfusões realizadas. Já em países em desenvolvimento como África do Sul, o risco residual de contaminação por 
HIV é de uma contaminação para 11.000 transfusões realizadas. Nos Estados Unidos o risco de contaminação residual de HIV na era Pré-NAT era de uma contaminação para 600.000 transfusões realizadas e, com a implantação do novo método de testagem sorológica (NAT) passou a ser de uma contaminação para 2.000 .000 transfusões realizadas ${ }^{83}$.

No Brasil, a Agência Nacional de Vigilância Sanitária (ANVISA) possui um Sistema Nacional de Hemovigilância no qual por meio do Sistema de Notificações em Vigilância Sanitária (NOTIVISA) os serviços de hemoterapia devem informar a ocorrência de reação transfusional. Como essa notificação ainda não é imposta por lei, ainda há um índice elevado de estimativa de subnotificações no país.

No ano de 2007, ocorreram 4.002.417 transfusões, com apenas 1.785 reações transfusionais notificadas à ANVISA - desse número, foi contabilizada um percentual de $85,1 \%$ de subnotificações, sendo que para totalizar esta estimativa utilizou-se a proporção de ocorrências de incidentes transfusionais de três reações para cada mil transfusões realizadas, baseados nos moldes da França e Holanda que estimam que em cada mil transfusões de sangue realizadas ocorram duas a três reações transfusionais (2-3/1.000 transfusões $)^{150}$. 
Quadro 3 - Frequência e percentual de notificações de reações transfusionais à ANVISA, classificadas por tipo de reação ocorridas no Brasil em 2007 e 2008.

\begin{tabular}{|c|c|c|c|c|}
\hline Diagnóstico de reação & Frequência 2007 & $\%$ & Frequência 2008 & $\%$ \\
\hline Febril não hemolítica & 899 & 50,3 & 1.311 & 50,2 \\
\hline Alérgica & 611 & 34,2 & 931 & 35,6 \\
\hline Anafilática & 16 & 0,9 & 16 & 0,6 \\
\hline Contaminação bacteriana & 4 & 0,2 & 6 & 0,2 \\
\hline $\begin{array}{l}\text { Hemolítica aguda } \\
\text { imunológica }\end{array}$ & 13 & 0,7 & 6 & 0,2 \\
\hline $\begin{array}{l}\text { Lesão pulmonar associada à } \\
\text { transfusão TRALI }\end{array}$ & 17 & 0,9 & 6 & 0,2 \\
\hline Hemolítica aguda não imune & 3 & 0,1 & 5 & 0,2 \\
\hline Hipotensiva & 7 & 0,4 & 8 & 0,3 \\
\hline Sobrecarga de volume & 42 & 2,3 & 73 & 2,8 \\
\hline Outras reações imediatas & 128 & 7,2 & 125 & 4,8 \\
\hline Doença transmissível & 0 & 0,0 & 7 & 0,3 \\
\hline Hemolítica tardia & 2 & 0,1 & 4 & 0,2 \\
\hline $\begin{array}{l}\text { Anticorpos } \\
\text { irregulares/isoimunização }\end{array}$ & 39 & 2,2 & 94 & 3,6 \\
\hline Outras reações tardias & 4 & 0,2 & 5 & 0,2 \\
\hline Total & 1785 & 100 & 2613 & 100 \\
\hline
\end{tabular}

Fonte: Anvisa ${ }^{151}$

Em uma análise simplista dos números supramencionados, vemos que as reações transfusionais são as consequências possíveis da atividade e não se resumem somente à contaminação por doenças transmissíveis. 
Dessa maneira, caso a execução da terapia transfusional resulte em dano ao paciente, o conhecimento do processo nos possibilita determinar quem são os profissionais envolvidos em cada etapa do procedimento, qual o grau de ingerência que cada um possui direta ou indiretamente sobre essas ações, assim como, se houve algum tipo de infração às normas existentes e se houve liame de causalidade entre a ação realizada e o resultado prejudicial obtido.

Por todo o exposto, concluímos que a terapêutica transfusão de sangue é uma atividade de risco, uma vez que os danos da técnica são possíveis e mensuráveis.

\subsection{DA PREVISÃO LEGAL ACERCA DA RESPONSABILIDADE} TRANSFUSIONAL

Azevedo $(2004)^{152}$ nos explica a origem da palavra "responsabilidade", in verbis:

"A palavra responsabilidade descende do verbo latino "respondere", de "spondeo", primitiva obrigação de natureza contratual do direito quiritário, romano, pela qual o devedor se vincula ao credor nos contratos verbais, por intermédio de pergunta e resposta ("Spondere mihi dare Centum? Spondeo"; ou seja, prometes me dar um centro? Prometo). Como é de notar-se, a ideia da palavra é a de responder por algo."

A responsabilidade médica já era prevista no Código de Hamurabi (2394 a.C.), que dizia que médicos ou cirurgiões que cometessem lesões corporais ou matassem um homem livre ou escravo poderiam ser punidos ${ }^{153}$. 
A Lex Aquilia de damno (468 d. C.) também punia a negligência, a imprudência e a imperícia. Foi o primeiro texto a prever a responsabilização médica com pena de morte ou deportação do médico culpado por infração profissional $^{154,155}$

Em 1602, o Parlamento de Paris proferiu o princípio da responsabilidade médica decorrente de acidentes advindos no tratamento médico, por esse princípio, o médico era responsável pelos resultados positivos ou negativos da terapia utilizada ${ }^{155,156}$.

Posteriormente, o Código Civil Francês de 1804 (arts. 1.382 e 1.383) e as leis e os códigos posteriores acabaram por estabelecer a teoria responsabilidade civil com os parâmetros de dever de reparação frente à prática de ato prejudicial a terceiro ${ }^{154,155}$.

No mesmo diapasão, Cavalieri Filho $(2007)^{156}$ prossegue:

"À luz do exposto, creio ser possível assentarmos duas premissas que nos servirão de suporte doutrinário. Primeira: não há responsabilidade, em qualquer modalidade, sem violação de dever jurídico preexistente, uma vez que responsabilidade pressupõe o descumprimento de uma obrigação. Segunda: para se identificar o responsável é necessário precisar o dever jurídico violado e quem o descumpri".

Conforme DINIZ (2004), a responsabilidade civil é uma sanção civil por derivar de regra de direito privado com função de proteção, interesse particular e também é compensatória por envolver reparação, ressarcimento ou indenização de dano causado por ato ilícito, contratual ou extracontratual e por ato lícito ${ }^{119}$ e complementa:

"Responsabilidade civil pressupõe uma relação jurídica entre a pessoa que sofreu o prejuízo e a 
que deve repará-lo, deslocando o ônus do dano sofrido pelo lesado para outra pessoa que, por lei, deverá suportá-lo, atendendo assim à necessidade moral, social e jurídica de garantir a segurança da vítima violada pelo autor do prejuízo. Visa, portanto, garantir o direito do lesado à segurança, mediante o pleno ressarcimento dos danos que sofreu, restabelecendo-se na medida do possível o status quo ante. Logo, o princípio que domina a responsabilidade civil na era contemporânea é o da restituitio in integrum, ou seja, da reposição completa da vítima à situação anterior a lesão, por meio de uma reconstituição natural, de recurso a uma situação material correspondente ou de indenização que represente do modo mais exato possível o valor do prejuízo no momento de seu ressarcimento" 119 .

O conceito de responsabilidade civil aplicável à hemoterapia está

disposto no Código Civil Brasileiro, nos artigos 186, 927, 949, 951, vejamos:

"Art. 186. Aquele que, por ação ou omissão voluntária, negligência ou imprudência, violar direito e causar dano a outrem, ainda que exclusivamente moral, comete ato ilícito."

"Art. 927. Aquele que, por ato ilícito (arts. 186 e 187), causar dano a outrem, fica obrigado a repará-lo.

Parágrafo único: Haverá obrigação de reparar o dano, independentemente de culpa, nos casos especificados em lei, ou quando a atividade normalmente desenvolvida pelo autor do dano implicar, por sua natureza, risco para os direitos de outrem."

"Art. 949. No caso de lesão ou outra ofensa à saúde, o ofensor indenizará o ofendido das despesas do tratamento e dos lucros cessantes até ao fim da convalescença, além de algum outro prejuízo que o ofendido prove haver sofrido."

“Art. 951. O disposto nos arts. 948, 949 e 950 aplica-se ainda no caso de indenização devida por aquele que, no exercício de atividade 
profissional, por negligência, imprudência ou imperícia, causar a morte do paciente, agravar-lhe o mal, causar-lhe lesão, ou inabilitá-lo para o trabalho."

Entretanto, há que se destacar que o Código de Defesa do Consumidor (CDC) prevê como direitos básicos do consumidor em seu art. $6^{0}:$

"I - a proteção da vida, saúde e segurança contra os riscos provocados por práticas no fornecimento de produtos e serviços considerados perigosos ou nocivos;

(...)

III - a informação adequada e clara sobre os diferentes produtos e serviços, com especificação correta de quantidade, características, composição, qualidade e preço, bem como sobre os riscos que apresentem;"

O CDC possui ainda uma seção de proteção à saúde e segurança que prevê:

"Art. 8․ Os produtos e serviços colocados no mercado de consumo não acarretarão riscos à saúde ou segurança dos consumidores, exceto os considerados normais e previsíveis em decorrência de sua natureza e fruição, obrigandose os fornecedores, em qualquer hipótese, a dar as informações necessárias e adequadas a seu respeito."

"Art. 9". O fornecedor de produtos e serviços potencialmente nocivos ou perigosos à saúde ou segurança deverá informar, de maneira ostensiva e adequada, a respeito da sua nocividade ou periculosidade, sem prejuízo da adoção de outras medidas cabíveis em cada caso concreto."

"Art. 10. O fornecedor não poderá colocar no mercado de consumo produto ou serviço que sabe ou deveria saber apresentar alto grau de nocividade ou periculosidade à saúde ou segurança." 
A RDC/MS nํ 153/04 define:

"Art. 14, § 4. A responsabilidade pessoal dos profissionais liberais será apurada mediante a verificação de culpa."

"A. 3 - A responsabilidade técnica e administrativa pelos serviços de hemoterapia deve ficar a cargo de um médico especialista em hemoterapia e ou hematologia, ou ser qualificado por órgão competente devidamente reconhecido para este fim pelo Sistema Estadual de Sangue. A este médico, o responsável técnico, cabe a responsabilidade final por todas as atividades médicas, técnicas e administrativas. Estas responsabilidades incluem o cumprimento das normas técnicas e a determinação da adequação das indicações da transfusão de sangue e de componentes."

"I.7.8 - O médico do serviço de hemoterapia pode suspender uma transfusão, quando considerá-la desnecessária. Estes casos devem ser discutidos no Comitê Transfusional da instituição."

Ao aplicarmos os ensinamentos de Hironaka mencionados anteriormente, podemos concluir que a norma regulamentadora da atividade hemoterápica no país, utiliza a expressão responsabilidade, quando parece estar considerando o conceito de obrigação.

No mesmo sentido, Cavalieri Filho (2007) $)^{156}$ diz:

"Em síntese, em toda obrigação há um dever jurídico originário, enquanto na responsabilidade há um dever jurídico sucessivo. Daí a feliz imagem de Larenz ao dizer que "a responsabilidade é à sombra da obrigação". Assim como não há sombra sem corpo físico, também não há responsabilidade sem a correspondente obrigação. Sempre que quisermos saber quem é o responsável teremos que identificar aquele a quem a lei imputou a obrigação, porque ninguém poderá ser 
responsabilizado por nada sem ter violado dever jurídico preexistente."

O Código Civil estabelece a teoria geral de responsabilidade civil vigente; o Código de Defesa do Consumidor trata das obrigações dos prestadores de serviços quando configurada uma relação de consumo e dos casos onde pode haver o dever de reparar o dano eventualmente causado na sua prestação; e a RDC/MS nº 153/04 determina a obrigação total do procedimento a um agente específico, o médico hemoterapeuta, o que não coaduna com a realidade das obrigações estabelecidas no processo.

\subsection{DAS RELAÇÕES JURÍDICAS}

O procedimento transfusional é uma atividade médica complexa que envolve vários profissionais e instituições com obrigações distintas que se relacionam entre si de maneira variada. Existem as obrigações do serviço de hemoterapia; do médico que indica o procedimento transfusional; do médico que acompanha a realização da transfusão; da equipe de enfermagem, que faz a infusão do hemocomponente; da instituição hospitalar que contrata ou possui um serviço de hemoterapia e do Estado como financiador, tutor e regulador das atividades hemoterápicas.

O Serviço de Hemoterapia enquanto: a) o fornecedor de hemocomponente a ser transfundido possui obrigação referente à execução dos procedimentos do ciclo do sangue (processo produtivo) em observância à RDC/MS no 153/04 e às demais legislações aplicáveis, desde a coleta até a liberação do hemocomponente para uso do serviço de hemoterapia, como 
também, o dever de fornecer o hemocomponente hígido e com as características solicitadas pelo médico que prescreveu a transfusão; b) o fornecedor de hemocomponentes e executor do procedimento transfusional tem obrigação referente à execução dos procedimentos do ciclo do sangue em observância à RDC/MS nº 153/04 e às demais legislações aplicáveis, desde a coleta até o fim da transfusão do hemocomponente, e, eventualmente, a identificação e tratamento das reações transfusionais que venham a ocorrer. Nesse caso, excetua-se o dever sobre a indicação transfusional que deve recair sobre o médico que efetuou a prescrição da transfusão; e, c) o avaliador das solicitações de hemocomponentes, o serviço de hemoterapia, por intermédio de seu médico hemoterapeuta ou do seu Comitê Transfusional, tem o dever de analisar as requisições de hemocomponentes e desaconselhar a realização da transfusão, conforme previsto no item I.7.8 da RDC/MS nำ 153/04.

Além disso, há que mencionar que o serviço de hemoterapia pode ser público ou privado, o que implica diretamente a implantação de novas técnicas disponíveis no mercado, uma vez que os serviços de hemoterapia públicos dependem do orçamento público para custear suas atividades; pode ou não pertencer à instituição hospitalar que fará a transfusão e/ou que mantenha vínculo com o médico que indicou a realização do procedimento; como também, pode ou não ter realizado todo o processo produtivo do hemocomponente.

Como já dissemos, o médico que prescreveu a transfusão de sangue tem a obrigação de: utilizar a conduta técnica mais segura e adequada para o paciente que está sendo tratado; analisar as condições clínicas do 
paciente; verificar se há alternativa terapêutica mais segura disponível antes de optar pela transfusão; avaliar os riscos e os benefícios da utilização da terapia transfusional; obter o consentimento informado do paciente, fazer a indicação da transfusão com base nos gatilhos transfusionais estabelecidos por instituições-referência como: American Association of Blood Bank $(\mathrm{AABB})^{9}$, International Society of Blood Transfusion (ISBT), Agência Nacional de Vigilância Sanitária (ANVISA) etc., ou pelos Comitês Transfusionais das Instituições Hospitalares que realizam transfusão de sangue e com isso determinar: o tipo de hemocomponente a ser infundido, a quantidade, e em alguns casos requisitar outras especificações ao hemocomponente, como por exemplo, aquecimento, filtração, irradiação, lavagem etc.

Vale ressaltar que o vínculo jurídico existente entre o médico, que decide e prescreve a transfusão de sangue, e a instituição hospitalar ou o serviço de hemoterapia, que realizará a transfusão, pode variar. O médico pode ser funcionário da instituição hospitalar ou do serviço de hemoterapia e, portanto, ser obrigado a seguir as diretrizes estabelecidas pela entidade, além de obedecer às normas vigentes ou ser autônomo e utilizar as dependências da instituição hospitalar, somente para executar seus serviços (isto pode ocorrer por intermédio da celebração de contratos de parceria, locação, cessão onerosa de espaço etc.) ou ainda poderá ser um prestador de serviço vinculado a outra pessoa jurídica, uma cooperativa, por exemplo.

O médico responsável pela supervisão da transfusão de sangue possui o dever de: acompanhar a transfusão; suspender a transfusão em casos de divergência de informações entre os dados pessoais do receptor e 
do hemocomponente que será infundido, ou de má aparência do hemocomponente; interromper imediatamente o procedimento transfusional quando o receptor apresentar algum desconforto ou reação durante a transfusão e encaminhar uma amostra de sangue pós-transfusão e a bolsa de componente infundida para análise do serviço de hemoterapia; diagnosticar e tratar as reações transfusionais que porventura ocorram.

A equipe de enfermagem que realizará a transfusão tem o dever de: coletar e identificar corretamente as amostras do receptor; verificar as condições clínicas do receptor e anotá-las no prontuário; conferir as informações pessoais do receptor e do hemocomponente a ser transfundido e anotá-las no prontuário; suspender a transfusão em caso de incongruência de informações entre os dados pessoais do receptor e do hemocomponente a ser transfundido; proceder à infusão; acompanhar os primeiros dez minutos de infusão à beira do leito do paciente; supervisionar constantemente o período restante de infusão; interromper a transfusão ao identificar alguma reação no receptor e chamar um médico para avaliar o paciente; anotar todos os procedimentos e reações no prontuário do paciente.

Cabe dizer que a equipe de enfermagem que realizará a transfusão pode ser composta por funcionários da instituição hospitalar e/ou do serviço de hemoterapia, e, portanto ser obrigada a seguir as diretrizes estabelecidas pela entidade, além das imposições legais, ou ainda ser terceirizada por intermédio de uma prestadora de serviços como uma cooperativa, por exemplo. 
A instituição hospitalar que realiza a transfusão de sangue e não possui seu próprio serviço de hemoterapia deve formalizar seu suprimento de hemocomponentes junto a um serviço de hemoterapia fornecedor, mediante a celebração de um contrato, convênio ou termo de compromisso (§ $3^{\circ}$, do art. $3^{\circ}$ da RDC/MS nำ $151 / 011^{157}$ e item T.1. RDC/MS no 153/04) que estabeleça inclusive o suprimento em caso de transfusão de extrema urgência (item I.1.2.d RDC/MS nำ153/04). No documento, carecerão constar as obrigações técnicas e financeiras de cada uma das partes, a obrigação de adequação e do transporte dos hemocomponentes, as penalidades para a não-execução das obrigações e a vigência da relação.

Neste sentido, o item A.4 da RDC/MS no 153/04 impõe que as instituições hospitalares que tenham atendimento de emergência, ou obstetrícia, ou que realizem cirurgias de médio porte, firmem contrato de fornecimento de hemocomponentes com um serviço de hemoterapia. Esse mesmo item determina que instituições hospitalares que realizam intervenções cirúrgicas de grande porte, ou que efetuem mais de 60 (sessenta) transfusões por mês, possuam, pelo menos, uma agência transfusional dentro das suas instalações. Logicamente, a instituição hospitalar deverá estabelecer uma relação de fornecimento com serviço de hemoterapia que cumpra as disposições legais e proveja o sangue dentro dos melhores padrões técnicos existentes. Cumpre evidenciar que as instituições hospitalares que realizem procedimentos transfusionais devem criar um Comitê Transfusional visando o estabelecimento de diretrizes internas voltadas à padronização de condutas técnicas procedimentais para minimizar os riscos da atividade. 
Por fim, há o dever do Estado como tutor e regulador do exercício da atividade hemoterápica, assim como possuidor e financiador do serviço de hemoterapia e/ou instituição hospitalar. Como tutor e regulador das atividades hemoterápicas, existe o dever de implantar e/ou cobrar a implantação das melhores técnicas disponíveis para redução dos riscos transfusionais, como por exemplo, a implantação do NAT, previsto na legislação há mais de seis anos e que até o momento não está sendo realizada nos serviços de hemoterapia públicos; por lhe pertencer o serviço de hemoterapia, há a obrigação de cumprir as diretrizes estabelecidas na RDC/MS no 153/04 e nas demais legislações aplicáveis; de possuir profissionais capacitados e treinados para execução das atividades (inclusive médico hemoterapeuta); e, por lhe pertencer a instituição hospitalar, há o dever de possuir profissionais capacitados e treinados para a execução das atividades (médicos que indiquem as transfusões e enfermeiros que realizem o procedimento); tutelar as atividades técnicas executadas (criação de Comitês); zelar pela integridade física, psíquica e moral dos pacientes e condições adequadas que contemplem os avanços em hemoterapia e a medicina em geral.

Ao considerarmos essas situações obrigacionais envolvendo um só procedimento, faz-se relevante a menção das definições de Cavalieri Filho $(2007)^{154}$

"Em síntese, nas obrigações de conteúdo determinado, a identificação do dever originário se faz com facilidade, em face da lei ou do negócio jurídico, que são sua fonte. Nas obrigações de conteúdo indefinido, entretanto, em que apenas 
se aponta para um fim (guardar, administrar, não causar dano etc.), sem indicação das condutas adequadas para atingir, teremos que descobrir em cada caso os atos que o obrigado deverá realizar para poder cumprir a obrigação originária. Vale dizer: o sujeito tem de integrar a norma, porque esta Ihe confia determinação dos atos que hão de constituir a conduta devida."

Estabelecidos esses paradigmas, caso haja um dano decorrente da transfusão de sangue, a busca pela indenização deve partir de uma retrospectiva das relações jurídicas supramencionadas para que haja a correta identificação do agente causador do dano e com isso a vítima possa pleitear eventualmente o devido ressarcimento.

\subsubsection{DA APLICAÇÃO DAS NORMAS VIGENTES}

Conforme exposto anteriormente, o conceito de responsabilidade civil aplicável à conduta hemoterápica está previsto no Código Civil Brasileiro nos artigos 186, 927, 949, 951. No entanto, alguns artigos do Código de Defesa do Consumidor, como os incisos I e III do art. $6^{\circ}$, art. $8^{\circ}$, art. $9^{\circ}$, art. $10^{\circ}$ e o $\S$ $4^{0}$ do art. 14 , também podem se enquadrar ao caso em questão.

Em alguns casos, a jurisprudência reconhece a atividade médica como uma prestação de serviço que estabelece uma relação de consumo entre as partes. Vejamos alguns casos:

"EMENTA: Responsabilidade civil. Dano moral. Infestação pelo vírus do HIV através de transfusão de sangue em hospital. Prova. Exibição de documentos. Depreendendo-se dos autos que 0 autor varão recebeu uma determinada quantia de sangue, só havendo prova de normalidade quanto à parte dela, assim 
mesmo produzida pelo próprio nosocômio unilateralmente, tem-se por cumprido o ônus probatório incumbido ao postulante da ação, a luz da doutrina da carga dinâmica probatória. Fato anterior ao $\mathrm{CDC}$. Serviço público delegado e consequente responsabilidade por este ângulo. Quantificação do dano. Atendendo-se às circunstâncias do fato, a gravidade do dano e do sofrimento, a obrigatoriedade de não causar o hospital doenças nos pacientes, ao caráter de sociedade de economia mista do ofensor, repartindo-se parte do ônus da condenação sobre toda a sociedade, bem como a parâmetros do órgão fracionário, e o valor da indenização fixado em 450 salários mínimos para cada autor, com juros de mora de $6 \%$ ao ano desde a data do fato. Sucumbência do vencido. Exibição de documentos. Prontuário médico e documento do paciente, que tem direito a recebê-lo. Circunstâncias normais, aliadas as do caso concreto, que conduzem a conclusão da recusa na entrega do prontuário. Procedência da ação. Sucumbência do requerido. Apelação provida. (TJ/RS. Apelação Cível no 70001195619, Nona Câmara Cível, Relatora: Des. Rejane Maria Dias de Castro Bins, Julgado em 30/08/2000.)" (Grifos nossos)

"Cuida-se de relação de consumo disciplinada pelo Código de Defesa do Consumidor, que estabelece a responsabilidade objetiva do prestador de serviços (art. 14).

É fato incontroverso que a autora, em 24.01.91, submeteu-se a cesariana realizada pelo segundo réu, Dr. CMCA recebendo a parturiente transfusão de sangue fornecido pela primeira ré.

A prova pericial concluiu que o procedimento médico foi adequado, tanto no tocante à cesariana quanto em relação à transfusão, necessária em razão de um processo de coagulação intravascular.

$A$ autora demonstrou que não era portadora do vírus da Hepatite "C" antes da transfusão, passando a apresentá-lo após o evento.

A primeira ré, por seu turno, nega que o vírus tenha sido contraído na transfusão de sangue.

Pelo exame dos autos, verifica-se que, quando do parto a autora contava com 35 anos de idade e sua gravidez era considerada de risco. 
Durante a preparação para cirurgia, todos os exames foram realizados e não houve comprovação de doença hepática anterior.

(...)

Nesse sentido, cabia a primeira ré adotar todas as cautelas que o caso impõe, certificando-se previamente da qualidade do sangue fornecido para transfusão.

Vale salientar que, à época do evento, embora não fosse obrigatório, já existia teste de sorologia hábil a detectar o vírus da Hepatite $C$.

Dessa forma, o nexo causal entre a conduta e o dano suportado foi demonstrado pela autora $e$ não refutado pela ré, resultando do exame conjunto das provas e indícios produzidos nos autos.

(...)

Por outro lado, a responsabilidade do segundo réu, de caráter subjetivo (art. 14, $\S 4^{\circ}$ do CDC), não restou demonstrada, pois o procedimento médico adequado ao caso foi adotado, inexistindo culpa profissional pelo dano suportado pela paciente." (TJ/RJ. Apelação Cível $n^{\circ}$ 2005.001.42582, Sexta Câmara Civil, Revisor designado. Des. Luis Felipe Salomão, Data do julgamento: 09/05/2006.)

"Ementa: APELAÇÃO CÍVEL - AGRAVO INTERPOSTO CONTRA O RECEBIMENTO DOS EFEITOS DA APELAÇÃO - RECEBIMENTO NA FORMA RETIDA PELO JULGADOR - DECISÃO IRRECORRIDA - PERDA DE OBJETO - AÇÃO DE INDENIZAÇÃO POR DANOS MORAIS E MATERIAIS - CONSUMIDOR - MENOR PACIENTE DE HOSPITAL CONTAMINADO PELO VÍRUS DA AIDS - FALECIMENTO NO CURSO DO PROCESSO - ENTIDADE QUE NÃO LOGROU COMPROVAR AUSÊNCIA DE SUA RESPONSABILIDADE PARA O EVENTO DANOSO - RISCO NA PRESTAÇÃO DO SERVIÇO - ÔNUS DA PROVA - INTELIGÊNCIA DO ART. 6ํㅡ, VIII E 14, DO CÓDIGO DE DEFESA DO CONSUMIDOR - ADEQUAÇÃO DA INDENIZAÇÃO POR DANOS MORAIS HONORÁRIOS DEVIDOS SOBRE AS PARCELAS VENCIDAS E DOZE DAS VINCENDAS." (TJ/RS. Apelação Cível $n^{\circ}$ 
2.0000.00.484233-7/000. Relatora. Des. Hilda Teixeira da Costa, data do julgamento: 09/03/2006, data da publicação: 13/05/2006.)

Note-se que em ambos os Códigos há previsão de implicação de responsabilidade civil objetiva, sem apuração de culpa, em questões que envolvam atividades de risco. Da mesma forma que em ambos os Códigos existe a disposição de responsabilização civil subjetiva, mediante apuração de culpa, dos profissionais liberais.

O Conselho Federal de Medicina, ao publicar o Novo Código de Ética Médica (Resolução CFM no 1931/2009), fez questão de explicitar em seu Capítulo I denominado Princípios Gerais que: "XX - A natureza personalíssima da atuação profissional do médico não caracteriza relação de consumo". Todavia não há como afastar a relação consumista da ligação paciente-hospital e talvez seja esse o ponto que induza os operadores de direito a fazer tal correlação.

Não cabe ao presente estudo discutir se a atividade médica caracteriza ou não uma relação de consumo segundo prevê a doutrina jurídica, visto que essa questão requer uma análise profunda do tema. Entretanto, vale salientar assim como dito acima que em ambos os Códigos o ponto tratado é o mesmo, ou seja, a dúvida entre a configuração da responsabilidade civil objetiva por ser a transfusão de sangue uma atividade de risco ou a configuração da responsabilidade subjetiva pelo fato de ser uma atividade médica. Dessa forma, em consonância com os ditames do Código de Ética Médica optaremos por abordar em relação à 
responsabilidade médica somente as normas do Código Civil, reiterando que as conclusões seriam as mesmas se adotassemos uma ou outra legislação.

Com intuito de esclarecer a ambiguidade sobre 0 adequado enquadramento da atividade hemoterápica, bem como as demais relações obrigacionais do processo, passaremos a analisar as duas vertentes do instituto da responsabilidade civil.

Assim, segundo Aguiar Junior $(2000)^{158}$ a responsabilidade civil originária da ação humana tem como hipótese a existência de uma conduta voluntária, o dano injusto sofrido pela vítima, que pode ser patrimonial ou extrapatrimonial; o nexo causal entre o dano e a ação do agente; o fator de conexão da responsabilidade pelo dano ao agente, de natureza subjetiva (culpa ou dolo), ou objetiva (risco, equidade etc.).

O art. 927 do CC em seu caput prevê a obrigação de indenizar mediante a apuração de culpa do agente e também dispõe em seu parágrafo único a obrigação de indenizar independentemente de haver culpa em casos específicos.

Juristas como Azevedo (2004) ${ }^{152}$ reconhecem a evolução que houve no Código Civil quando o legislador erigiu o dever de reparar - a teoria do risco como fonte legislativa, vejamos:

"Nesse ponto, o novo CC inova em duas situações: a responsabilidade objetiva pura, conforme o que estiver especificado em lei, e a responsabilidade objetiva pura, em razão do risco criado pela atividade do agente, 'por sua atividade normalmente desenvolvida', que 'implicar, por sua natureza, risco para o direito de outrem'." 
Pereira (2000) ${ }^{159}$ ao criticar o conceito geral de responsabilidade civil fundamentada na culpa do Código Civil de 1916, diz:

"Mais do que nunca é necessário dedicar-se o escritor à exposição da teoria do risco juntamente com a doutrina subjetiva. É que em qualquer circunstância quem se dedica à responsabilidade civil deve ter presentes duas fontes: a legislativa, pois que o dever ressarcitório há de se fundar basicamente em a norma definida no direito positivo; e a jurisprudencial, pois que na decisão dos casos em espécie, mesmo nos sistemas de direito escrito como é o nosso, encontrar-se-ão elementos que concorrem para atualizar a hermenêutica das normas legais aplicáveis e adminículos seguros e úteis para acompanhar $o$ desenvolvimento dos princípios."

Sobre a teoria do risco, Lima $(1938)^{160}$ ensina:

"O direito não surge por encanto, diz PEZELLA (432), mas pressupõe estrutura econômica suficiente para que sua ação possa se desenvolver e sintetizar-se. Assim sendo, dentro da estrutura econômica moderna, neste burburinho infernal de movimento criador de danos, impossível seria manter o princípio de igualdade, que deve reinar juridicamente entre os homens, nos moldes da teoria da culpa. (...) $A$ teoria objetiva da responsabilidade civil, partindo da verdade real e incontestável que a vida forneceu ao jurista - a criação da insegurança material da vítima, da desigualdade manifesta entre os criadores de riscos e aqueles que suportam os efeitos nocivos destes perigos criados - procurou na segurança jurídica, responsabilizando o homem pelo fato decorrente de sua atividade, aquela igualdade a que se refere o notável jurista italiano. (...) Materializouse a função da responsabilidade em face do dano, rebuscando somente o nexo de causalidade e o risco criado, para não se deixar a vítima inocente sem a reparação do mal sofrido pelo criador da atividade disseminadora de perigos." 
Um dos grandes defensores da responsabilidade civil objetiva, Dias $(2006)^{92}$, nos relata uma nova tendência jurisprudencial:

"O estudo de jurisprudência de um século na França revelou que a extrema prudência e circunspeção com que os juízes apreciam a responsabilidade médica. Não hesitam, é certo, em face dos casos de erro comum, como negligência, imprudência ou omissão. Quando, entretanto, a espécie envolve o exame da diretriz seguida pelo médico, do valor terapêutico ou da oportunidade da medicação ministrada ao doente ou da operação levada a efeito, crescem as dificuldades enfrentadas pelos tribunais que assim, pendem para a solução mais fácil, isto é, a irresponsabilidade. É em reação a essa timidez que se sustenta, energicamente - com o perigo, entretanto, de ir ao extremo oposto - que o médico deve responder por todo e qualquer erro, praticado ou não da boa-fé ou por mera ignorância das normas essenciais da arte, por inabilidade ou imperícia, deixando de prevenir ou remediar acidente evitável, grave ou leve."

Em posição diametralmente oposta à corrente doutrinária supramencionada, Carvalho (2004) ${ }^{161}$ define a situação de lesão ou sequela previsível decorrente de atividade médica como iatrogenia e nesses casos conclui pela exclusão de responsabilização dos médicos:

"Se por um lado, a lesão previsível - iatrogenia é resultado do atuar médico, por outro, a imprudência, a negligência e a imperícia são causas que, uma vez, comprovadas, geram reparação civil. Definida como lesão previsível ou sequela do tratamento decorrente da invasão do corpo, a iatrogenia, ou dano iatrogênico, é também identificado como dano necessário e esperado do atuar médico. A medicina moderna, ao conceituar a iatrogenia como todo dano causado ao paciente pela ação médica ou os 
males provocados pelo tratamento prescrito, estanca de forma direta o ingresso no campo da responsabilidade civil, já que os profissionais médicos que cuidam da saúde alheia, assumem a obrigação de meio com a finalidade de aplicar a arte, perícia e zelo que detêm e que seus pacientes presumem, cuja aferição eventual desvio não vai além da reparação terapêutica. Afastado, pois, o erro médico, conclui-se que o dano suportado pelo autor é iatrogênico, previsível e necessário ao que foi submetido o autor, decorrente pois, do atuar médico isento de responsabilidade civil."

Parnasco (1979), ao comentar a importância da responsabilidade médica, faz algumas considerações que confrontam o pensamento de Carvalho (2004):

"Na responsabilidade, tal como entende a lei civil, não se trata de capacidade mais ou menos ampla, de talento mais ou menos brilhante, mais ou menos sólido, senão somente da garantia contra a imprudência, a negligência e a ignorância crassa das coisas que se deviam

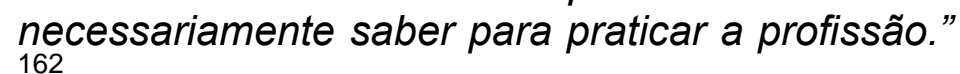

Alguns juristas como Kfouri Neto $(2007)^{163}$ e Azevedo, M. (2002) ${ }^{164}$ reconhecem que a transfusão de sangue em si é um tratamento médico, por essa razão, caso ocorra algum prejuízo ao paciente, a conduta deve ser tratada sob a égide do art. 951 ou do caput do 927, ambos do CC, que determinam a responsabilização do profissional pela teoria da responsabilidade subjetiva que pressupõe a apuração de culpa.

Nesse ponto, cabe o adendo de que a transfusão de sangue é tão e somente $\mathrm{o}$ ato de infundir o sangue ou o hemocomponente em um paciente que não necessariamente é realizado pelo médico que fez a prescrição médica e que é o responsável pela exposição ou não do paciente ao risco. 
Todavia, existem processos anteriores, como exemplo o processo de produção e liberação do hemocomponente para uso, bem como as obrigações concorrentes, como exemplo, os deveres da enfermagem, que influem diretamente no resultado da atividade.

Para Kfouri Neto (2007) ${ }^{163}$ a culpa médica dever ser apurada sob o enfoque da teoria da responsabilidade subjetiva, no entanto ele define que o serviço de hemoterapia pode ser objetivamente responsabilizado sobre a obrigação de fornecimento de sangue hígido:

"se houver erro grosseiro, por exemplo, na coleta do sangue ou no próprio ato de transfusão" (...) "Pode-se configurar, também responsabilidade objetiva da entidade que forneceu o sangue Banco de Sangue ou agência coletadora." (...) "Provas de compatibilidade pré-transfusionais são obrigatórias - de responsabilidade do médico que realiza a transfusão, não de quem indica."

Cavalieri Filho $(2007)^{156}$ define os elementos necessários para a apuração da conduta culposa:

a) “Conduta voluntária com resultado involuntário;

b) Previsão ou previsibilidade; e,

c) Falta de cuidado, cautela, diligência ou atenção."

Portanto, toda atividade médica, como também toda a atividade exercida por profissional liberal no decorrer do processo, deve ser avaliada segundo a teoria da responsabilidade subjetiva, nos termos do art. 951 do CC ou até mesmo do $\S 4^{\circ}$ do art. 14 do CDC.

Cumpre ressaltar que caso decorra algum dano do processo transfusional, o médico que fez a indicação e a prescrição da transfusão de sangue nos termos do art. 951 do CC, também deverá responder pelo dano 
(responsabilidade solidária - art. 942 CC), se agir com negligência, imprudência ou imperícia ao efetuar equivocadamente a prescrição e indicação de transfusão na exposição indevida do paciente ao risco potencial.

Entretanto, como vimos no transcorrer deste trabalho, existem outras etapas do processo que podem influir no resultado final da transfusão.

Conforme mencionamos anteriormente, os eventuais danos podem ou não ocorrer em virtude do procedimento transfusional em si, por esse motivo, se sobrevier algum dano ao receptor para que haja uma responsabilização justa é necessária a segregação das fases do processo para a avaliação correta das obrigações e a identificação exata dos possíveis culpados.

Nessa relação, há que dizer que as instituições hospitalares e os serviços de hemoterapia responderão objetiva e solidariamente, caso seus funcionários, auxiliares ou prepostos sejam culpados pelos eventos danosos ocorridos ao paciente, em razão da presunção JURES ET JURE, de culpa in vigilando da relação contratual existente perante as instituições (arts. 932, III; 933 e parágrafo único do art. 942 todos do CC e Súmula 341 do STJ) ${ }^{165}$. A seguir transcreveremos alguns Acórdãos relacionados a esse tema:

"Depreende-se dos autos que o autor, em janeiro de 1995, permaneceu internado no Hospital SL, na cidade de Teófilo Otoni, durante um tratamento contra meningite. Encontrando-se em estado grave, o menor foi submetido a uma transfusão de sangue.

Cerca de um ano após o ocorrido, o apelado apresentou um quadro de "infecção respiratória recorrente, diarreia associada à inapetência", segundo o Dr. GA (f. 248), médico que o 
consultou e acabou por diagnosticar a contaminação pelo vírus HIV.

Quando o apelado foi internado no hospital réu, este não teve o cuidado de realizar os exames para verificar se aquele era ou não portador do vírus da AIDS. A nosso ver, foi um equívoco.

É fato incontroverso a realização da transfusão de sangue no autor, uma vez que confirmada pelo próprio hospital. No entanto, verifica-se que o apelante não mantém em seus registros os dados completos dos doadores de sangue, conforme exigência da legislação pertinente, visto que sequer conseguiu localizar o doador do sangue utilizado para o tratamento do apelado.

Ademais, não foi apresentado o resultado do exame realizado no material (sangue) utilizado na transfusão, que atestasse a inexistência do vírus HIV.

Ora, a conduta do réu demonstra sua negligência, o que é inconcebível para uma instituição de tamanha relevância, já que lida diretamente com a vida das pessoas."

"Aliás, é notória a contradição entre os depoimentos do representante legal do réu, Dr. $O E$, e do Dr. GT, quanto ao Banco de Sangue.

O Dr. OE afirma que 'o Hospital dispunha de Banco de Sangue, sob a responsabilidade do Dr. GT' e que 'o sangue para transfusão era coletado no hospital, amostras eram enviadas para o Dr. GT, ficando o sangue estocado no Hospital'. (f. 149).

No entanto, o Dr. GT que não tem informações precisas sobre as pessoas que constam na listagem de dezembro de 1994. Ora, sendo o Banco de Sangue de sua responsabilidade, no mínimo, deveria ter todos os dados dos doadores. O Dr. JMS afirma que cada doador tinha uma ficha de controle e a cada doação o sangue era examinado. Segundo ele, o controle ficava no fichário do Banco de Sangue, além do livro constando o rol dos doadores e das fichas (f. 
268/269). Ocorre que foi apresentado um caderno constando, tão somente, o nome do doador, o tipo de sangue, data da coleta e quantidade do material. Não há identificação detalhada dos doadores, muito menos o resultado dos exames realizados.

É nítida a falta de controle do réu sobre o material coletado.

A nosso ver, restou comprovada a realização da transfusão de sangue no autor, pelo hospital réu, o contágio pelo vírus HIV e o nexo de causalidade. Assim, demonstrada a responsabilidade do apelante, passamos ao quantum indenizatório." (Tribunal de Justiça de Minas Gerais, Apelação $n^{0}$ 2.0000.00.4073385/000 (1), Relator: Des. Alvimar de Ávila, data do julgamento: 17/3/2004, data da publicação: 3/4/2004.)

"Conforme já exposto no relatório, I.C.P. ajuizou ação de indenização contra o Hospital S.J.B. e o Estado de Santa Catarina, objetivando o ressarcimento por danos morais e materiais decorrentes da contaminação pelo HIV, agente causador da Síndrome da Imunodeficiência Adquirida - SIDA/AIDS.

No caso em questão, a apelada, em 24/5/1997, foi submetida à cirurgia de curetagem uterina no Hospital S.J.B., e, diante de considerável perda de sangue, necessitou de transfusões que resultaram no recebimento de sangue contaminado com o vírus HIV, fornecido pelo Banco de Sangue do mesmo hospital, originando na aquisição do vírus da AIDS.

Com efeito, a controvérsia suscitada pelo Estado de Santa Catarina restringe-se à análise da existência ou não do nexo causal entre a conduta realizada pelo Hospital S.J.B., que realizou a transfusão na apelada do sangue contido na bolsa 505, o qual estava contaminado pelo vírus HIV, uma vez que a Central Sorológica de Criciúma estava mantendo sob suspeita o material, tendo 
em vista que no mapa onde eram catalogados os exames apontava a sua inutilização.

O Estado de Santa Catarina alega, em suas razões de apelação, que 'para melhor situar a relação entre o Hospital e o Estado de Santa Catarina, o Banco de Sangue no qual foi utilizado o sangue contaminado era de responsabilidade total do Hospital S.J.B. Ltda., estando sediado fisicamente nesse local, operado por funcionários do Hospital, que se encarregavam da coleta, guarda e utilização do sangue e derivados' (fl.366).

No entanto, infere-se dos autos que o Hospital S.J.B. recebia os doadores para a coleta de sangue, e após o seu recolhimento em porções separadas, as amostras eram enviadas à Central Sorológica, subsidiária do HEMOSC, na cidade de Criciúma. Esta unidade, por sua vez, realizava os exames necessários e detectava eventuais infecções em caráter preventivo. Assim, a Central preenchia um mapa, indicando os códigos relativos a cada doador, como também os testes que deveriam ser realizados. Com este documento, verificava-se se o sangue poderia ser transfundido aos pacientes que porventura viessem a necessitá-lo.

O sangue contaminado que a apelada recebeu estava na bolsa 505 que, de acordo com o mapa elaborado pela Central Sorológica em 21/5/1997 (fls. 42), havia a necessidade da elaboração de novos exames referentes à hepatite $B$ e HIV. Contudo, no dia 23 de maio de 1997, um dia antes da transfusão, o mapa colacionado às fls. 41 demonstra a indicação do caráter nãoreagente no novo exame de Hepatite $B$ realizado, sendo que no espaço destinado a informações acerca do HIV, não foi acrescentado nenhuma ressalva. Para tanto, somente em 12 de junho de 1997, quase 20 dias após transfusão, é que a Central descreveu no mapa de exames que o vírus HIV estava reagente na bolsa 505 (fl.43).

Dessa forma, verifica-se ser evidente a responsabilidade da Central Sorológica, pois, 
conforme afirmado pelo próprio Estado, cabia-Ihe 'tão somente promover a análise das amostras enviadas pelo Hospital e, após, remeter 0 resultado, através de mapa' (fl. 366).

Ora, a análise dos sangues doados não pode ser caracterizada como uma singela atividade prestada pelo Estado pela Central Sorológica, a qual se constitui numa instituição que, presumese, reunir profissionais especializados na coleta, análise, separação e distribuição do sangue, bem como de seus componentes. Nesse sentido, surge o dever do Estado de fiscalizar e controlar o sangue, cujo fluxo deve ser infinitas vezes mais relevantes do que qualquer outro produto, que, inclusive, exigia ações concretas, eficazes e imediatas diante de quaisquer rumores que denunciassem perigo à saúde dos usuários do sistema-médico hospitalar. Entretanto, esse não foi o caminho seguido.

\section{(...)}

O procedimento realizado pela Central Sorológica demonstra a falha do sistema adotado pelo Estado, uma vez que alguns servidores da Central realizavam a confirmação dos exames por telefone. Constata-se também que, após o triste ocorrido, a Central Sorológica passou a agir com mais rigor, deixando de repassar resultados de exames por telefone, e que após a instalação do HEMOSC na cidade de Criciúma, esta unidade passou a coletar e examinar o sangue recolhido e a preencher todos os espaços dos mapas dos exames sorológicos.

Flagrante, pois, a negligência estatal, decorrente de medidas tardiamente iniciadas, tendo em vista que a instituição da política nacional do sangue data de 1965, através da Lei $n^{0}$ 4.701, ratificada pela Lei $n^{0}$ 7.649, de 25 de janeiro de 1988, que estabeleceu 'a obrigatoriedade do cadastramento dos doadores de sangue bem como a realização de exames laboratoriais no sangue coletado, visando prevenir a propagação de doenças'. 
Dessa forma, constata-se que a Central Sorológica não agiu de acordo com os dispositivos legais pertinentes aos serviços hemoterápicos, deixando de controlar e fiscalizar um serviço essencial. Constata-se que, além de enviar em branco o Mapa dos Exames Sorológicos referente à bolsa 505 (fls. 41/42), não fez nenhuma anotação quanto ao resultado do teste Anti-HIV.

Note-se ainda que agiu com descaso ao ter devolvido ao Hospital o sangue contaminando, liberando a sua utilização por telefone. No entanto, tal fato não pode mitigar a responsabilidade do Hospital S.J.B., conforme se verá a seguir.

\section{(...)}

O Hospital S.J.B. também alegou, em suas razões de apelação, a inexistência de culpa por sua parte, uma vez que o fato foi desencadeado por culpa da Central Sorológica do Estado, a quem coube a responsabilidade de realizar os exames para aferir a qualidade do sangue, tendo, ainda, a obrigação legal de fiscalizá-los, não havendo por que liberar o resultado por telefone. Afirmou também que possui uma relação de sujeição à Central Sorológica, a qual detém o monopólio dos exames de sangue.

Pois bem, conforme informado na peça contestatória (fls. 129/135) e ratificado nas razões de recurso (fls.333/334), o Hospital apelante era o responsável pela coleta de sangue, que, ao receber os doadores, coletava-lhes o sangue $e$ armazenava-o separadamente das outras porções coletadas, sendo que uma delas era enviada para a Central Sorológica.

No entanto, não pode ser atenuada a sua responsabilidade, pois inexistia, no momento da transfusão, a comprovação documental de que o sangue poderia ser transmitido à apelada, devendo ter sido desconsiderada a liberação da bolsa 505 por telefone. Ademais, infere-se dos documentos de fls. 41/43 que os exames definitivos referentes ao teste Anti-HIV somente 
foram realizados quando a transfusão já havia ocorrido.

\section{(...)}

Destarte, a existência de uma relação de subordinação entre a Central Sorológica e o Estado de Santa Catarina não exclui a responsabilidade do Hospital no triste ocorrido. Visto que, ao transfundir o sangue da bolsa 505 à apelada, não possuía em mãos o mapa elaborado pela Central, pois, de acordo com o depoimento já reproduzido, eram frequentes as informações acerca dos exames por telefone, as quais eram anotadas num "caderninho de rascunho", e que os mapas ficavam aguardando a sua retirada pelo Hospital na Central Sorológica.

Ora, o Hospital não poderia ter transfundido o sangue na apelada haja vista que não existia prova documental sobre a sua qualidade, ou seja, o mapa dos exames que era elaborado pela Central não estava no Hospital, e sim à espera da sua retirada na própria Central. Assim, mesmo que fosse frequente o contato por telefone entre a Central Sorológica e o Hospital, é de se considerar tal ato negligente, pois a falta de formalidade que existia fez com que as partes tomassem novas medidas de procedimento após $o$ acontecido.

Como visto, o Hospital S.J.B. deve também ser responsabilizado pelo evento, pois não produziu qualquer prova que pudesse suprimir a sua responsabilidade. Outrossim, elucida-se que os mapas anexados ao processo demonstram que 0 exame Anti-HIV foi realizado em momento após a transfusão.

Assim, por restar positivado nos autos, através da prova testemunhal e documental, o nexo de causalidade entre o fato e o dano, considera-se suficiente o dever de indenizar do Hospital S.J.B." (TJ/SC. Apelação cível no 2001.003210-4, Primeira Câmara de Direito Público, Relator: Des. Nicanor da Silveira, data do julgamento: 27/5/2004.) 
Ainda sobre os serviços de hemoterapia, devemos evidenciar que além da obrigação JURES ET JURE pelos atos de seus funcionários ou prepostos, aqueles igualmente podem ser responsabilizados em decorrência das infrações procedimentais à RDC/MS no 153/04 e legislações correlatas, como também pelas contaminações por doenças infecciosas ocasionadas pela transfusão de sangue que é um risco real da atividade.

Sobre a transgressão das legislações técnicas aplicáveis é evidente a configuração de responsabilidade nos termos do art. 927, caput do CC e pelo viés do CDC haveria a imputação em função da prestação imprópria do serviço ( $\S 2^{\circ}$, art. $20 \mathrm{CDC}$ ). Porém, em relação às contaminações por doenças infecciosas ocasionadas pela transfusão de sangue, existe uma corrente jurisprudencial que define esse fato como excludente de responsabilidade civil frente à ocorrência de um caso fortuito caracterizado pela inevitabilidade do evento e pela ausência de culpa dos serviços que realizam triagens sorológicas dentro dos padrões preconizados pela $\mathrm{RDC} / \mathrm{MS} \mathrm{n}^{\mathrm{0}}$ 153/04.

Todavia, quando explicamos no decorrer do presente trabalho que a atividade transfusional é uma atividade de risco, trouxemos para análise a diferença percentual de contaminação em razão da transfusão entre a utilização da técnica de testagem sorológica NAT, que reduz o período de janela imunológica para detecção dos vírus supramencionados sobre as técnicas previstas na RDC/MS nำ153/04.

Por outro lado, o fato da não utilização da melhor técnica disponível pode e deve ser entendido como um descaso das instituições frente ao risco 
envolvido na transfusão, ainda mais ao considerarmos que a utilização deste método de testagem está normatizado e vigente há pelo menos seis anos.

Note-se que, segundo Sabino et al. (1999) ${ }^{166}$ a taxa de incidência de contaminação pelo vírus HIV entre os anos de 1996 a 1998, em 114.103 doadores analisados da Fundação Pró-Sangue Hemocentro de São Paulo foi de 25,9 (IC 95\%: 18,2 a 36,1) por 100 mil pessoas-ano. Entre 1997 e 1999, Kupek ${ }^{167}$ fez um estudo semelhante com 11.286 doadores do Hemocentro de Santa Catarina para o vírus HCV e determinou a taxa de incidência de 51 (IC 95\%: 23 a 99) por 100 mil pessoas-ano para este vírus.

Deste modo, se a atividade é potencialmente arriscada e é notória a existência da janela imunológica, os serviços de hemoterapia devem utilizar todos os meios hábeis acessíveis no mercado para realizar suas atividades, visando à mitigação do risco para somente assim, concluírem pela impossibilidade de impedir a ocorrência do dano. Neste caso, o enquadramento da responsabilidade civil seguiria os termos do art. 927, caput do CC e sob a ótica do CDC existiria a atribuição de culpa de acordo com a prestação imprópria do serviço (§ 2ํㅡㄹ. art. 20 CDC).

A última questão a ser tratada é a responsabilidade do Estado sobre a questão hemoterápica. A doutrina brasileira é unânime em admitir a responsabilidade objetiva do Poder Público sobre as atividades, pois no momento em que ele desempenha papel de prestador de serviços the é imputada a responsabilidade objetiva, como previsto no art. 37 . $\S 6^{\circ}$ da Constituição Federal.

Nesse sentido di Pietro (1999) ${ }^{168}$ dispõe: 
"Todos parecem concordar em que se trata de responsabilidade objetiva, que implica averiguar se o dano teve como causa o funcionamento de um serviço público, sem interessar se foi regular ou não."

Este é o entendimento unânime da jurisprudência, vejamos:

"Pelo relatório de fls. 114/121, firmado pela equipe obstétrica de plantão, a paciente chegou ao hospital com um sangramento vaginal intermitente, em regular estado geral, com feto vivo, em boa vitalidade (fls. 114). Todavia, o quadro evoluiu para pior, com aumento do sangramento vaginal com o feto já apresentando bradicardia fetal e a paciente com pulso fino e mucosa descorada. Com a evolução do quadro para pior, chegou-se à conclusão da necessidade de uma cesariana (fls. 115).

No curso da intervenção cirúrgica, houve necessidade de transfusão sanguínea. Ocasião em que se verificou um procedimento incorreto dos médicos, Dr. ZC e Dr. SML (fls. 152), que, sem a coleta do sangue da paciente para a contraprova da tipagem, ordenaram à enfermeira EAS providenciar o sangue $A$ (positivo) para a paciente. Observe-se que o Banco de Sangue estava fechado (fls. 154) e o local da chave foi indicado pelo Dr. Z (fls. 143), que fez anotação de $A$ (positivo) na requisição de sangue (fls. 151).

A negligência médica deve ser anotada, principalmente, do médico anestesista, que olvidou a respectiva coleta, como medida preparatória da cirurgia e aceitou o sangue sem examinar o prontuário da paciente que já estava internada no hospital há dois dias (fls. 153).

Faltou, portanto, ao anestesista a previsibilidade da eventual necessidade de transfusão de sangue. O nexo de previsibilidade é o supedâneo da conduta culposa no âmbito do Direito. Se ausente a previsibilidade, a culpa não se faz presente.

A vítima recebeu doação de sangue incompatível, pois era '0+', ou seja do tipo doador universal, só podendo receber de outro igual, noção que nenhum médico ou paramédico podia ignorar, por ser noção abecedária, acessível até a qualquer pessoa não ligada ao sistema de saúde. 
A vítima foi internada devido a um quadro hemorrágico intenso e foi submetida a um tratamento cirúrgico, havendo necessidade de transfusão, recebendo sangue incompatível, sem os cuidados de anterior coleta para a contraprova da tipagem, valendo-se o médico, de forma descurada de informes da paciente, sem se preocupar em consultar o prontuário da vítima, que já estava internada há dois dias. Sua morte por septicemia foi decorrente de complicações intra e pós-operatórias (fls. 206), por receber sangue incompatível e contaminado com o vírus HIVIAIDS.

Interessante anotar que o sangue incompatível e contaminado com o vírus HIV/AIDS contribuiu para a morte, com intensa relação de nexo de causalidade com o quadro septicêmico final (fls. 206).

A transfusão de sangue incompatível e contaminado com o vírus HIVIAIDS foi desencadeante do óbito da vítima. Caso não houvesse a inadequada transfusão, o quadro septicêmico poderia ser diagnosticado clinicamente (febre, calafrios, mal-estar geral, insuficiência circulatória aguda (schock séptico). Utilizando-se do recurso laboratorial que permite, quando efetuado com oportunidade, isolar a bactéria responsável pelo mal, o que é de suma importância para orientação terapêutica medicamentosa (antibióticos).

Mas a transfusão do sangue incompatível, agravado pelo vírus HIV/AIDS, tornou o quadro septicêmico de evolução irreversível, ocasionando a morte da paciente. '(*...) Há intensa relação do nexo de causalidade com o quadro septicêmico final', conforme concluiu o laudo pericial do Instituto de Medicina Social e de Criminologia de São Paulo (IMESC) de fls. 206/207.

A responsabilidade dos agentes da Administração está caracterizada. A culpa no campo médico pela negligência sobre a coleta de sangue, antes de iniciar-se a cirurgia, pois é sempre previsível a eventual utilização de sangue. Soma-se, ainda, a circunstância de não ter sido efetuada a coleta de sangue para tipagem, ordenando à enfermagem proceder à transfusão de sangue do tipo $A$ (positivo), quando a paciente só podia receber do tipo $O$ (positivo). 
O fato incontroverso, admitido pela ré em sua resposta de fls. 174, é que a vítima chegou ao Hospital MCL com choque hipovolêmico. A hipovolemia consiste na diminuição da massa de sangue circulante no organismo. Tal circunstância era mais do que suficiente para evitar-se a conduta da equipe obstétrica de expectativa de evolução para pior do quadro da paciente, evidenciando-se, na oportunidade, o sangramento vaginal constante (fls. 114). Este estado não podia ser classificado como regular, mas, sim, de alarma, providenciando-se a abertura do Banco de Sangue, com a vinda de funcionário habilitado, a fim de proceder às necessárias provas sorológicas para afastar a sífilis, o vírus HIVIAIDS, a moléstia de Chagas e Hepatite $B$, além da indispensável contraprova com a coleta do sangue da paciente para a necessária tipagem.

Por outro lado, é inadmissível que o médico anestesista fosse para uma cirurgia de paciente hipovolêmica, sem ter à sua disposição a bolsa de sangue adequada, com todos os resultados das provas sorológicas e a respectiva tipagem. Não se alegue emergência, pois houve a conduta médica da expectativa (fls. 114) da evolução do quadro para pior. A menos que se queira argumentar a inexistência de previsibilidade de um quadro hipovolêmico que, com sangramento intermitente, não possa piorar. Aguardava a equipe obstétrica que o quadro hipovolêmico, com sangramento intermitente pudesse melhorar, sem qualquer providência médica? Ou era previsível que a hipovolemia, sem interferência de cuidados médicos adequados, pudesse melhorar? O nexo da previsibilidade evidenciado não afasta a culpa da equipe obstétrica.

Indiscutível a culpa dos médicos com procedimentos inadequados, especialmente do anestesista, e a responsabilidade do pessoal paramédico, ignorando noções abecedárias sobre a compatibilidade de transfusão sanguínea. Há, portanto, concorrência subjetiva, culposa dos médicos, com a responsabilidade objetiva do Município, estando provado o nexo etiológico, justificando-se a indenização pelo dano moral causado aos menores, em decorrência da responsabilidade objetiva, conforme preceito constitucional (CF, $\S 6^{-}$do art. 37)." (Tribunal de Justiça do Estado de São Paulo, Apelação Cível 
$n^{0}$ 101.749-5/2-00, Relator: Des. Alberto Zvirblis, Quinta Câmara de Direito Público, data do julgamento: 9/8/2001.)

Ao mesmo tempo, o Poder Público é o financiador, tutor e regulador das atividades hemoterápicas. Destarte, sob o mesmo prisma da responsabilidade objetiva descrito acima ele poderá ser responsabilizado pelo descaso na implantação e fiscalização de medidas que tenham por objetivo o aumento da segurança transfusional, ressaltando que não é somente a concretização da utilização da técnica NAT que fará mudanças significativas em favor da segurança transfusional, o Relatório da OMS de novembro/2009 ${ }^{78}$ diz que os países devem implementar critérios mais rígidos para seleção de doadores e incentivar a doação voluntária, altruísta e não remunerada; direta ou indiretamente essas mudanças podem e devem ser feitas sob a égide do art. 196 da CF:

"Art. 196 - A saúde é direito de todos e dever do Estado, garantido mediante políticas sociais e econômicas que visem à redução do risco de doença e de outros agravos e ao acesso universal e igualitário às ações e serviços para sua promoção, proteção e recuperação." (grifos nossos)

Assim sendo, a hemoterapia é uma especialidade médica e deve ser exercida por profissionais que detenham o conhecimento necessário para executá-la. Não basta a presunç

ão do conhecimento, deve haver a certeza dos riscos frente à administração de um produto potencialmente nocivo, e caso haja algum prejuízo ao paciente a legislação civil vigente nos oferece a possibilidade de responsabilização do(s) agente(s) causador (es) do dano. 
6.Conclusões 
Em face de todo o exposto, concluímos que a terapêutica transfusional é uma atividade médica e de risco que deve ser executada em estrita observância à legislação técnica competente.

Mesmo que haja toda cautela e observância das normas vigentes, podem ocorrer reações transfusionais prejudiciais à saúde do paciente. Como acontece em todo tratamento médico, efeitos adversos são incomuns, mas esperados, e podem não ser originários de erros de conduta dos profissionais envolvidos nos processos.

Apesar disso, caso haja alguma intercorrência danosa originária da atividade transfusional, o Código Civil Brasileiro e o Código de Defesa do Consumidor possuem mecanismos que proporcionam a justa classificação da responsabilidade (objetiva ou subjetiva) do agente causador e a devida reparação dos danos causados. 
7. Referências Bibliográficas 
1. Stedman dicionário médico. Traduzido por Araujo CLC, Vanzelloti IR, Lemos Jl, Azevedo MF. Rio de Janeiro: Guanabara Koogan. 25a edição ilustrada, 1996. p. 1355.

2. Brasil. Ministério da Saúde. Secretaria de Atenção à Saúde. Departamento de Atenção Especializada. Guia para o uso de hemocomponentes. Brasília: Ministério da Saúde; 2008. p. 11.

3. Oliveira LCO, Cozac APC, NC. Reações transfusionais: diagnóstico e tratamento. In: Simpósio: Urgências e Emergências Hematológicas. Capítulo II.

4. Madjdpour C, Heindi V, Spahn DR. Risks, benefits, alternatives and indications of allogenic blood transfusion. Minerva Anestesiol. 72(5).

5. Mendrone Jr, A. Transfusão sanguínea. Diagnóstico e tratamento. Sociedade Brasileira de Clínica Médica. São Paulo: Manole; v. 2.

6. Brasil. Ministério da Saúde. Agência Nacional de Vigilância Sanitária. Manual técnico de hemovigilância. Brasília/DF: MS; 2004. (Série A. Normas e Manuais Técnicos).

7. Serious Hazards of Transfusion. Haemovigilance and experience of the serious hazards of transfusion. Scheme in the United Kingdom (UK), 21st, November, 2005.

8.Chamone DAF, Novaretti MCZ, Dorlhiac-Llacer PE. Manual da transfusão de sangue. São Paulo: Manole; 2001.

9. American Association of Blood Banks. Technical manual. 13th ed. Bethesda: AABB; Chap: 27-8.

10. British Committee for Standards in Haematology Blood Transfusion Task Force. The administration of blood and blood components and the management of the transfused patient. Transf Med. 1999. 
11. Serious Hazards of Transfusion. Shot in the arm for safer blood transfusion. BMJ. 1996;313(7076).

12. Healthy Service Circular. Better Blood Transfusion - Appropriate use of blood. Julho, 2002.

13. Willianson ML. Systems contributing to the assurance of transfusions safety in the United Kingdon. Vox Sanguinis. 77.

14. Cappi F. La transfusione del sangue dalle origine ai nostril giorni. Available from: http://www.medicalsystems.it/editoria/Caleido_Lette/CalLettPDF/7Cappi.pdf.

15. Wintrobe MM. Blood pure and enloquent. US: McGraw-Hill Inc.; 1980. p. 660.

16. Red Gold, the epic history of blood. Mirror of the soul - $2500 \mathrm{BCe}-999 \mathrm{Ce}$. Available from: http://www.pbs.org/wnet/redgold/history/timeline1.html.

17. Rossi EC, Simon TL, Moss GS. Transfusion in transition. In: Principles of transfusion medicine. Baltimore: Williams \& Wilkins; 1991. p. 1.

18. Novaretti MCZ. História da medicina transfusional. Fundação Pró-Sangue Hemocentro de São Paulo; 2004.

19. Stanford Encyclopedia of Phylosofy. Alcmaeon. Available from: http://plato.stanford.edu/entries/alcmaeon/.

20. Ness PM. Transfusion medicine: an overview and update. Clin Chemistry. 2000;46:1270-6.

21. Wikipedia. Biles negra. Disponível em: http://pt.wikipedia.org/wiki/B\%C3\%ADlis_negra, consultado em 9/3/09.

22. Encyclopedia Britannica. Taurobolium. Disponível em: http://www.britannica.com/EBchecked/topic/584394/Taurobolium, consultado em 12/3/09. 
23. Souza MASM. A arte médica em Roma antiga nos de Medicina de Celso. Disponível em: http://www2.dlc.ua.pt/classicos/De\%20medicina.pdf, consultado em 12/3/09.

24. Ala Al-Din Abu al-Hasan Ali Ibn Abi Al-Hazm Al-Qarshi Ibn Al-Nafis Al Damishqui, Ibn al-Nafis. Available from: http://www.dec.ufcg.edu.br/biografias/lbnNafis.html, consultado em 10/3/09.

25. Wintrobe MM. Blood pure and enloquent. US: McGraw-Hill Inc.;1980. p. 660.

26. Wintrobe MM. Blood pure and enloquent. US: McGraw-Hill Inc.;1980. p. 661.

27. Global Oneness. Blood transfusion. Available from: http://www.experiencefestival.com/a/Blood_transfusion/id/430458, consultado em 7/3/09.

28. Puro Sangue. História da transfusão de sangue. Disponível em: http://purosangue.wordpress.com/historia-da-transfusao-de-sangue/, consultado em 7/3/09.

29. Gonzales TT. Impacto da mudança do perfil dos doadores de sangue na evolução dos marcadores sorológicos para HIV e Doença de Chagas na Fundação Pró-Sangue no período de 1995 a 2001. [Tese]. São Paulo: Faculdade de Medicina da Universidade de São Paulo; 2003.

30. Red Gold, the epic history of blood. Status quo under fire - 1000-1699. Available from: http://www.pbs.org/wnet/redgold/history/timeline2.html, consultado em 10/3/09.

31. Wikipedia. Andrea Caesalpino. Disponível em: http://en.wikipedia.org/wiki/Andrea_Caesalpino, consultado em 12/3/09. 
32. BBC Home. William Harvey (1578-1657). Available from: http://www.bbc.co.uk/history/historic_figures/harvey_william.shtml, consultado em 10/3/09.

33. Wikipedia. Willian Harvey. Disponível em: http://en.wikipedia.org/wiki/William_Harvey, consultado em 10/3/09.

34. Greenwalt TJ. A short history of transfusion medicine. . 1999;37:550-63.

35. Swammerdam's Science. Swammerdam's microscopes. Available from: http://www.janswammerdam.net/techno.html, consultado em 10/3/09.

36. Starr Douglas. "Blood: an epic history of medicine and commerce". New York: First Quill, 1998. p. 8.

37. Wintrobe MM. Blood pure and enloquent. US: McGraw-Hill Inc.; 1980. p. 662.

38. Vialibri. Claude Tardy. Available from: http://www.vialibri.net/item_pg/27116231654-tardy-claude-collection-works-follows-traitt\%E9-mouvement-circulaire-sang-des.htm

39. Wintrobe MM. Blood pure and enloquent. US: McGraw-Hill Inc.; 1980. p. 664.

40. Red Gold. The epic history of blood. William Hewson. Available from: http://www.pbs.org/wnet/redgold/innovators/bio_hewson.html, consultado em 18/3/09.

41. Red Gold. The epic history of blood. Discovery and exploration - 1700-1919. Available from: http://www.pbs.org/wnet/redgold/history/timeline3.html, consultado em 18/3/09.

42. Greenwalt TJ. Transfusion: the first decade. Transfusion. 1999;37(1):91-2.

43. Wintrobe MM. Blood pure and enloquent. US: McGraw-Hill Inc.; 1980. p. 668.

44. Wintrobe MM. Blood pure and enloquent. US: McGraw-Hill Inc.; 1980. p. 669. 
45. Wintrobe MM. Blood pure and enloquent. US: McGraw-Hill Inc.; 1980. p. 671.

46. Wintrobe MM. Blood pure and enloquent. US: McGraw-Hill Inc.; 1980. p. 688.

47. Junqueira PC, Rosemblit J, Hamerschlak. História da hemoterapia no Brasil. Rev Bras Hematol Hemoter. 2005;27(3):201-7.

48. Nobel Prize (org). The nobel prize in physiology or medicine 1930. Available from: http://nobelprize.org/nobel_prizes/medicine/laureates/1930/index.html, consultado em 18/3/09.

49. Wintrobe MM. Blood pure and enloquent. US: McGraw-Hill Inc.; 1980. p. 676.

50. Hess JR. The first blood banker: Osvald Hope Roberteson. Transfusion. 2000;40:110-3.

51. Wintrobe MM. Blood pure and enloquent. US: McGraw-Hill Inc.; 1980. p. 670.

52. Wintrobe MM. Blood pure and enloquent. US: McGraw-Hill Inc.; 1980. p. 673.

53. Wintrobe MM. Blood pure and enloquent. US: McGraw-Hill Inc.; 1980. p. 672.

54. Wintrobe MM. Blood pure and enloquent. US: McGraw-Hill Inc.; 1980. p. 678.

55. Schmidt PJ. John Elliot and the evolution of American blood bank, 1934 to 1954. Transfusion. 2000;40:608-12.

56. Wintrobe MM. Blood pure and enloquent. US: McGraw-Hill Inc.; 1980. p. 682.

57. Loutit, JF, Mollison PL, Maureen Young I, Lucas EJ. Citric acid-sodium citrateglucose mixtures for blood storage. Quarterly Journal of Experimental Physiology and Cognate Medical Sciences 32.3 p. 183-202. Available from: http://ep.physoc.org/cgi/content/abstract/32/3/183, consultado em 19/3/09. 
58. Brasil. Lei no 1075, de 27 de março de 1950. Dispõe sobre a doação voluntária de sangue. Diário Oficial da União, Rio de Janeiro, no 83, 12 abr. 1950. Seção 1, p. 5425.

59. Brasil. Lei no 4701, de 28 de junho de 1965. Dispõe sobre o exercício da atividade hemoterápica no Brasil e dá outras providências. Diário Oficial da União, Brasília, no 123, 1 jul. 1965. Seção 1, pt.1. p. 6113-4.

60. Brasil. Comissão Nacional de Hemoterapia. Portaria no 1, de 25 de abril de 1968. Estabelece os conceitos das operações desempenhadas pelos órgãos executivos de atividade hemoterápica, dos agentes hemoterápicos, do doador de sangue e receptor de transfusão. Diário Oficial da União, Brasília, no 96, 21 maio 1968. Seção 1, pt.1. p. 4078-9. Alterados itens: 9 do título I e 6.3 do Título II, pela Portaria no 2, de 30/10/1968.

61. Brasil. Comissão Nacional de Hemoterapia. Portaria no 4, de 25 de setembro de 1969. Estabelece instruções sobre a rotina de atendimento a doadores para a realização da operação de coleta de sangue. Diário Oficial da União, Brasília, no 10, 15 jan.1970. Seção 1, pt.1. p. 343-5.

62. World Health Organization. Screening donated blood for transfusiontransmissible infections: recommendations. Geneve 2010. Available in http://www.who.int/bloodsafety/ScreeningDonatedBloodforTransfusion.pdf.

63. Brasil. Lei no 6437, de 20 de agosto de 1977. Configura infrações à legislação sanitária federal, estabelece as sanções respectivas e dá outras providências. Diário Oficial da União, Brasília, no 162, 24 ago. 1977. Seção 1, pt.1. p. 11145-50.

64. Absolute Astronomy. Blood bank. Available from: http://www.absoluteastronomy.com/topics/Blood_bank, consultado em 19/3/09.

65. Brasil. Ministério da Saúde. Gabinete do Ministro. Portaria Interministerial no 7 Bsb., de 30 de abril de 1980. Aprova as diretrizes básicas do Programa Nacional de 
Sangue e Hemoderivados-Pró-Sangue. Define as atribuições da COMART, instituída pela Portaria Interministerial MS/MPAS no 2, de 11 de fevereiro de 1980. Diário Oficial da União, Brasília, no 85, 8 maio 1980. Seção 1. p. 8226-9.

66. Learoyd P. A short history of blood transfusion. National Blood Service Scientific \& Technical Training. January, 2006.

67. São Paulo (Estado). Lei no 5190, de 20 de junho de 1986. Dispõe sobre a realização de testes para detecção de anticorpos do vírus da Síndrome da Deficiência Imunológica Adquirida (AIDS). Diário Oficial do Estado. São Paulo, 21 jun. 1986. Seção 1. v. 96, no 116. p.1.

68. Brasil. Ministério da Previdência e Assistência Social. Gabinete do Ministro. Portaria Interministerial MPAS/MS no 14, de 18 de maio de 1987. Determina que a aplicação transfusional de sangue e hemoderivados, patrocinada com recursos da Previdência, seja procedida pelos testes sorológicos necessários à detecção e confirmação da infecção pelo agente AIDS. Diário Oficial da União, Brasília, no 92 , 20 maio 1987. Seção 1. p. 7536-7.

69. Brasil. Lei no 649, de 25 de janeiro de 1988. Estabelece a obrigatoriedade do cadastramento dos doadores de sangue, bem como a realização de exames laboratoriais no sangue coletado, visando prevenir a propagação de doenças e dá outras providências. Diário Oficial da União, Brasília, no 18, 27 jan. 1988. Seção 1. p. 1609.

70. Brasil. Ministério da Saúde. Gabinete do Ministro. Portaria no $721 \mathrm{GM}$, de 9 de agosto de 1989. Aprova normas técnicas para a coleta, o processamento e a transfusão de sangue, componentes e derivados e dá outras providências. Diário Oficial da União, Brasília, no 153, 11 ago. 1989. Seção 1. p.13643-13650. Revogada pela Portaria no 103, de 6/2/2003.

71. Reitman J. Bad blood - Crisis in the American Red Cross. New York: Kesington; 1996. p. 45. 
72. São Paulo (Estado). Secretaria da Saúde. Centro de Vigilância Sanitária. Portaria CVS 10, de 30 de junho de 1992. Dispõe sobre a obrigatoriedade de todos os estabelecimentos hemoterápicos realizarem testes individualizados para pesquisa de Hepatite $C$, na seleção pré-transfusional e pré-industrial e dá outras providências. Diário Oficial do Estado. São Paulo, 1 jul. 1992. Seção 1. v. 102, no 123. p. 30. Revogada pela Portaria CVS 1, de 6/1/1994.

73.Brasil. Ministério da Saúde. Gabinete do Ministro. Portaria no 1376, de 19 de novembro de 1993. Aprova alterações na Portaria no 21/GM, de 9 de agosto de 1989, que institui normas técnicas para coleta, processamento e transfusão de sangue, componentes e derivados e dá outras providências. Diário Oficial da União, Brasília, no 229, 2 dez. 1993. Seção 1. p. 18405-15. Revogada pela Portaria no 103, de 6/2/2003.

74. Brasil. Ministério da Saúde. Gabinete do Ministro. Portaria n.262, de 05 de fevereiro de 2002. Torna obrigatório, no âmbito da Hemorrede Nacional, a inclusão nos Serviços de Hemoterapia públicos, filantrópicos e/ou privados contratados pelo SUS, e privados, os testes de amplificação e detecção de ácidos nucléicos (NAT), para HIV e HCV, em todas as amostras de sangue de doadores. Diário Oficial da União, Brasília, n.26, 06 fev. 2002. Seção 1, p.49.

75. Brasil. Ministério da Saúde. Gabinete do Ministro. Portaria n.1407, de 01 de agosto de 2002. Determina a inclusão, no âmbito da Hemorrede Nacional, nos Serviços de Hemoterapia públicos, filantrópicos, privados contratados pelo SUS, e exclusivamente privados, a realização de testes para detecção de ácidos nucléicos (NAT) para o vírus da Imunodeficiência Humana (HIV) e o vírus da Hepatite C (HCV), nas amostras de doadores. Diário Oficial da União, Brasília, n.148, 02 ago. 2002. Seção 1, p.33.

76. Brasil. Ministério da Saúde. Gabinete do Ministro. Portaria n.79, de 31 de janeiro de 2003. Determina a implantação, no âmbito da Hemorrede Nacional, nos Serviços de Hemoterapia públicos, filantrópicos, privados contratados pelo SUS, e exclusivamente privados, a realização dos testes de amplificação e de detecção de 
ácidos nucléicos (NAT) para HIV e para HCV, nas amostras de sangue de doadores. Diário Oficial da União, Brasília, n.24, 03 fev. 2003. Seção 1, p.20.

77. Brasil. Ministério da Saúde. Gabinete do Ministro. Portaria n.112, de 29 de janeiro de 2004. Dispõe sobre a implantação e realização, no âmbito da Hemorrede Nacional, de testes de amplificação e detecção de ácidos nucléicos (NAT) para HIV e HCV. Diário Oficial da União, Brasília, n.21, 30 jan. 2004. Seção 1, p.71-72.

78. World Health Organization. Availability, safety and quality of blood products. Report by the Secretariat. Executive Board EB126/19. 126th Session 19 November 2009. Provisional agenda item 4.16.

79. American Association of Blood Bank. Terapêutica Transfusional - Manual para médicos traduzido para o português por Nukui, Y, Cliquet, MG. 3a ed. em português, 2003. p. 1.

80. Brasil. Ministério da Saúde. Resolução de Diretoria Colegiada. RDC/MS no $153 / 04$.

81. Brasil. Fundação Pró-Sangue Hemocentro de São Paulo. Disponível em: http://www.prosangue.sp.gov.br/prosangue/actiondoacao.do?acao=requisitos

82. World Health Organization. Who Library Cataloguing-in-Publication Data Screening donated blood for transfusion-transmissible infections: recommendations, 2010. $\quad$ p. $3 . \quad$ Available In: http://www.who.int/bloodsafety/ScreeningDonatedBloodforTransfusion.pdf. 
83. Almeida N. Perfil epidemiológico de doadores de sangue com diagnóstico sorológico de HIV e Sífilis. [Tese de Doutorado]. São Paulo: Faculdade de Medicina da Universidade de São Paulo; 2007.

84. CLT. Art. 473 - O empregado poderá deixar de comparecer ao serviço sem prejuízo do salário (...) IV - por 1 (um) dia, em cada 12 (doze) meses de trabalho, em caso de doação voluntária de sangue devidamente comprovada.

85. Brasil. Ministério da Saúde. Resolução do Conselho Nacional de Saúde no 196/96, de 10 de outubro de 1996.

86. Dorlhiac-Llacer PE. Doação de sangue e testes laboratoriais no sangue do doador, In: Chamone DAF, Novaretti MCZ, Dorlhiac-Llacer PE. Manual de transfusão sanguínea. São Paulo: Roca; 2001.

87. Allain JP, Stramer SL, Carneiro-Proietti ABF, Martins ML, Lopes da Silva SN, Ribeiro M, Proietti FA, Reesink HW. Transfusion-transmitted infectious diseases. Published by Elsevier Ltd. Available from: www.sciencedirect.com.

88. Mayr WR. New frontier in blood transfusion. ISBT Science Series. 2008;3:37-8.

89.

Salves.

Virologia.

Disponível

em: http://74.125.93.104/search?q=cache:8Sbnh5uuBoEJ:www.salves.com.br/virtua/aidsvirol.ht $\mathrm{m}+\mathrm{variante}+$ +virais $\& \mathrm{~cd}=2 \& \mathrm{hl}=\mathrm{pt}-\mathrm{BR} \& \mathrm{ct}=\mathrm{clnk} \& \mathrm{gl}=\mathrm{BR}$. 
90. Dodd RY. Emerging transfusion infections: species barriers and the risk for transfusion medicine. ISBT Science Series. 2008;3:71-76.

91. Bush MP. Human immunodeficiency virus: a global problem with ongoing implications for transfusion medicine. ISBT Science Series. 2008;3:170-174.

92. Allain JP, Candotti D. Current problems with detection and transmission of hepatitis viruses. ISBT Science Series. 2008;3:104-106.

93. Kleinman S. Blood donor screening with nucleic acid amplifications tests for human immunodeficiency virus, hepatitis $\mathrm{C}$ virus and hepatitis $\mathrm{B}$ virus. ISBT Science Series. 2008;3:191-195.

94. Bush MP, Lee LL, Satten GA, Henrard DR, Farzadegan H, Nelson KE, Read S, Dodd RY, Petersen LR. Time of detection of viral and serologic markers preceding human immunodeficiency virus type 1 seroconversion: implications for screening of blood and tissue donors. Transfusion. 2003;35:91-97.

95. Otani MM. Programa de avaliação externa para os testes de triagem sorológica de doadores de bancos de sangue dos centros de referência da América Latina: utilização de multipainel específico. [Tese] São Paulo: Faculdade de Ciências Farmacêuticas da Universidade de São Paulo; 2003. 
96. Weusten JJAM, Van Drimmelen HAJ, Nico L. Mathematic modeling of the risk of HBV, HCV and HIV transmission by window-phase donations not detected by NAT. Transfusion. 2002;42:537-548.

97. Fundação Pró-Sangue Hemocentro de São Paulo. Procedimento operacional padrão POP 022-003, Tipagem ABO-Rh, Revisão 07.

98. Bain BJ. Células sanguíneas - um guia prático. Traduzido por Failace R. 3a ed. Porto Alegre: Artmed; 2004. p. 69.

99. Bain BJ. Células sanguíneas - um guia prático. Traduzido por Failace R. 3a ed. Porto Alegre: Artmed; 2004. p. 91.

100. Bain BJ. Células sanguíneas - um guia prático. Traduzido por Failace R. 3a ed. Porto Alegre: Artmed; 2004. p. 126.

101. Fundação Pró-Sangue Hemocentro de São Paulo. O sangue e seus constituintes.

Disponível

em:

www.prosangue.sp.gov.br/prosangue/arquivos/curiosidades/O-sangue-e-seusconstituintes.ppt. Consultado em 26/4/09.

102. Brasil. Ministério da Saúde. Secretaria de Atenção à Saúde. Departamento de Atenção Especializada. Guia para o uso de hemocomponentes. Brasília: Ministério da Saúde; 2008. p. 16 
103. Faber JC. Quality management in blood establishments: with special emphasis on the European situation. ISBT Science Series. 2008;3:18-25.

104. Mintz PD. Quality assessment and improvement of blood transfusion pratices. In: Mintz PD. Transfusion therapy: clinical principles and practice, 2nd ed. Bethesda: AABB; 2005.

105. Mendrone JR. A. Transfusão sanguínea. In: Diagnóstico e tratamento. v. 2, Sociedade Brasileira de Clínica Médica. Manole: Antônio Carlos Lopes; 2006. p. 895.

106. Fundação Pró-Sangue Hemocentro de São Paulo. Procedimento operacional padrão POP 020-002, Manuseio, Armazenamento, Embalagem, Preservação e Entrega de Componentes Sanguíneos.

107. World Healthy Organization. The clinical use of blood. Available from: http://www.who.int/bloodsafety.

108. Murpy MF, Brunskill S, Stanworth S, Dorée C, Roberts D, Hyde C. How to further develop the evidence base for transfusion medicine. ISBT Science Series. $2008 ; 3: 45-47$.

109. Sibinga GTS, Murphy MF. Hemovigilance: an approach to risk management in transfusion medicine. In: Mintz PD. Transfusion therapy: clinical principles and practice, 2nd ed. Bethesda: AABB; 2005 
110. American Association of Blood Banks. Technical Manual 12-14th ed. Standarts 1-22nd ed. Versão em CD-Rom.

111. Isbister JP. Transfusion practice in clinical care. ISBT Science Series. 2008; 3:8-12.

112. Petrides M, Aubuchon JP. To transfusion or not transfuse: an assessment of risk and benefits. In: Mintz PD. Transfusion therapy: clinical principles and practice, 2nd ed. Bethesda: AABB; 2005

113. Becker JL. Administration of blood components. In: Mintz PD. Transfusion therapy: clinical principles and practice, 2nd ed. Bethesda: AABB; 2005.

114. Brofin ED. Overview of medical-legal issues in transfusion medicine in United States. In: Mintz PD. Transfusion therapy: clinical principles and practice, 2nd ed. Bethesda: AABB; 2005.

115. Hospital das Clínicas da Faculdade de Medicina da Universidade de São Paulo. Comitê de Bioética (Cobi). Disponível em: www.hcnet.usp.br/adm/dc/cobi/parecer/parecer_06_2005.pdf

116. Hospital das Clínicas da Faculdade de Medicina da Universidade de São Paulo. Comissão de Avaliação e Controle em Medicina Transfusional (CACTM). 
Padronização para utilização de sangue e hemocomponentes no Hospital das Clínicas da Faculdade de Medicina da Universidade de São Paulo.

117. Gomes EFP, Jorge CR. Testes pré-transfusionais. In: Chamone DAF, Novaretti MCZ, Dorlhiac-Llacer PE. Manual de transfusão sanguínea. São Paulo: Roca; 2001.

118. Brasil. Ministério da Saúde. Secretaria de Atenção à Saúde. Departamento de Atenção Especializada. Guia para o uso de hemocomponentes. Brasília: Ministério da Saúde; 2008. p. 28.

119. Diniz MH. O estado atual do biodireito - atualizado conforme novo Código Civil (Lei no 10.406, de 10 de janeiro de 2002) e Lei de Biossegurança (Lei no 11.105, de 24 de março de 2005). 3a edição. São Paulo: Saraiva; 2006. p. 6-8.

120. Reale M. Lições preliminares de Direito. 22a edição. São Paulo: Saraiva; 1995. p. 29.

121. Durand G. Introdução geral à bioética - histórias, conceitos e instrumentos. São Paulo: Loyola; 2003. p. 20.

122. Reale M. Lições preliminares de Direito. 22a edição. São Paulo: Saraiva; 1995. p. 31-32. 
123. Hironaka GMF. Bioética e biodireito: revolução biotecnológica, perplexidade humana e prospectiva jurídica inquietante. Elaborado em 08/2001. In: http://jus2.uol.com.br/dourtina/texto.asp?id=4193, consultado em 1/4/2010.

124. França GV. Direito médico. 3a edição. São Paulo: Fundo Editorial BykProcienx; 1982. p.3.

125. Reale M. Lições preliminares de Direito. 22a edição. São Paulo: Saraiva; 1995. p. 65.

126. Perlingieri P. Perfis do Direito civil, introdução ao Direito civil constitucional. 3a edição. Rio de Janeiro: Renovar; 2002. p. 104-105.

127. Brasil. Código de Ética Médica - Resolução no 1931/2009. Conselho Federal de Medicina. Publicada no Diário Oficial da União, Brasília, 24 set. 2009. Seção I, p. 90. Retificação publicada no Diário Oficial da União, Brasília, 13 out. 2009. Seção I, p. 173.

128. Perlingieri P. Perfis do Direito civil, introdução ao Direito civil constitucional. 3a edição. Rio de Janeiro: Renovar; 2002. p. 90.

129. Perlingieri P. Perfis do Direito civil, introdução ao Direito civil constitucional. 3a edição. Rio de Janeiro: Renovar; 2002. p. 96. 
130. Perlingieri P. Perfis do Direito civil, introdução ao Direito civil constitucional. $3 a$ edição. Rio de Janeiro: Renovar; 2002. p. 9-10.

131. Brasil. Constituição da República Federativa do Brasil. Brasília: Senado Federal; 1988.

132. Moraes MCB. Danos à pessoa humana - uma análise Civil-Constitucional dos Danos Morais. Rio de Janeiro: Renovar; 2003. p. 182.

133. Moraes MCB. O princípio da dignidade humana. In: Princípios do Direito Civil Contemporâneo. Moraes MCB. (Coordenador) Rio de Janeiro: Renovar; 2006. p. 5

134. Martins-Costa, JH. Bioética e dignidade da pessoa humana: rumo à construção do biodireito. In: Revista Trimestral de Direito Civil. São Paulo: Padma; 2000; Vol. 3, (jul./set.2000). p. 66.

135. Moraes A. Direito Constitucional. 8a edição, atualizada com a EC no 28/00. São Paulo: Atlas; 2000. p.48.

136. Moraes MCB. Danos à pessoa humana - uma análise Civil-Constitucional dos Danos Morais. Rio de Janeiro: Renovar; 2003. p. 185.

137. Moraes MCB. O princípio da dignidade humana. In: Princípios do Direito Civil Contemporâneo. Moraes MCB. (Coordenador) Rio de Janeiro: Renovar; 2006. p. 15. 
138. Brasil. Conselho Federal de Medicina. Resolução CFM no 1931/2009. Diário Oficial da União, Brasília, 24 set. 2009. Seção I, p. 90. Retificação publicada no Diário Oficial da União, Brasília, 13 out. 2009. Seção I, p.173.

139. Perlingieri P. Perfis do Direito civil, introdução ao Direito civil constitucional. 3a edição. Rio de Janeiro: Renovar; 2002. p. 38.

140. Rey L. Dicionário de termos técnicos de medicina e saúde. Rio de Janeiro: Guanabara Koogan; 2003. p. 813.

141. Burity T. A propósito de direito médico. In: Direito Médico. França G V. 3a edição. São Paulo: Fundo Editorial Byk-Procienx; 1982. p. XV.

142. França GV. Direito médico. 3a edição. São Paulo: Fundo Editorial BykProcienx; 1982. p.XIX.

143. Brasil. Lei no 10205, de 21 de março de 2001. Diário Oficial da União, Brasília, no 57-E, 22 mar. 2001. Seção 1, p. 1-2.

144. Brasil. Decreto no 3990, de 30 de outubro de 2001. Diário Oficial da União, Brasília, no 209, 31 out. 2001. Seção 1, p. 1-3.

145. Brasil. Lei no 6.437, de 20 de agosto de 1977. Diário Oficial da União, Brasília, 24 ago. 1977. 
146. Hironaka GMFN. Responsabilidade pressuposta. Belo Horizonte: Del Rey; 2005. p. 355.

147. World Health Organization. Aide-memoire - Blood Safety. Available from: http://www.who.int/bloodsafety/clinical_use/en/Aide-Memoire_23.3.04.pdf.

148. Chamone DAF, Saez-Alquezar A., Salles NA., Bassit L., Sabino E. Triagem sorológica em bancos de sangue. In: Chamone DAF, Novaretti MCZ, DorlhiacLlacer PE. Manual de transfusão sanguínea. São Paulo: Roca; 2001.

149. Dias JA. Da responsabilidade civil. XI edição revisada, atualizada e ampliada de acordo com o Código Civil de 2002 por Rui Berford Dias. Rio de Janeiro: Renovar; 2006.

150. Brasil. Ministério da Saúde. Agência Nacional de Vigilância Sanitária. Boletim de Hemovigilância no 2. Brasília/DF: MS; 2009. p. 7. Disponível em: http://www.anvisa.gov.br/sangue/hemovigilancia/boletim_hemo_2009.pdf

151. Brasil. Ministério da Saúde. Agência Nacional de Vigilância Sanitária. Boletim de Hemovigilância no 02. Brasília/DF: MS; 2009. p. 10.

Brasil. Ministério da Saúde. Agência Nacional de Vigilância Sanitária. Boletim de Hemovigilância no 02. Brasília/DF: MS; 2009. p. 10.

152. Azevedo AV. Teoria geral das obrigações - responsabilidade civil. 10a edição. São Paulo: Ed. Atlas; 2004. p. 266. 
153. Parnasco WL. A responsabilidade civil, penal e ética dos médicos. Rio de Janeiro: Forense; 1979. p. 35.

154. Diniz MH. Curso de Direito Civil Brasileiro - Responsabilidade Civil; vol. 7. 18a edição revista, aumentada e atualizada de acordo com o Novo Código Civil (Lei no 10.406, de 10 de janeiro de 2002 e Projeto de lei no 6.960/2002. São Paulo: Saraiva; 2004. p. 12-13.

155. Parnasco WL. A responsabilidade civil, penal e ética dos médicos. Rio de Janeiro: Forense; 1979. p. 37.

156. Cavalieri Filho C. Programa de responsabilidade civil. 7a edição revista e ampliada. São Paulo: Ed. Atlas; 2007.

157. Brasil. Ministério da Saúde. Agência Nacional de Vigilância Sanitária. Diretoria Colegiada. Resolução RDC no 151, 21 agosto 2001. Diário Oficial da União. Brasília, no 161-E, 22 agosto 2001. Seção 1. p. 29-31

158. Aguiar Júnior RR. Responsabilidade civil do Médico. 2000. Disponível em: http://bdjur.stj.gov.br/dspace/handle/2011/555.

159. Pereira CMS. Responsabilidade civil - revista e atualizada de acordo com a Constituição de 1988. 9a edição. Rio de Janeiro: Forense; 2000. p. 280. 
160. Lima A. Da culpa ao risco. São Paulo: Ed. Revista dos Tribunais; 1938. p. 220221.

161. Tribunal de Justiça do Rio Grande do Sul. Relator Desembargador Maldonado de Carvalho. Apelação no 11.913/2004, 9a Câmara Cível. Votação unânime.

162. Parnasco WL. A responsabilidade civil, penal e ética dos médicos. Rio de Janeiro: Forense; 1979. p. 43.

163. Kfouri Neto M. Responsabilidade civil do médico. 6a edição revista, atualizada e ampliada. São Paulo: Ed. Revista dos Tribunais; 2007. p. 69.

164. Azevedo MAV. AIDS e responsabilidade civil. São Paulo: Atlas; 2002. p. 83.

165. Diniz MH. Curso de Direito Civil Brasileiro - Responsabilidade Civil, 7o volume. 18a edição revista, aumentada e atualizada de acordo com o Novo Código Civil (Lei no 10.406, de 10/1/2002 e o Projeto de Lei no 6.960/2002). São Paulo: Ed. Saraiva; 2004. p. 347.

166. Sabino EC, Salles N, Saez-Alquezar A, Ribeiro GS, Chamone DF, Busch MP. Estimated risk of transfusion-transmitted HIV infection in São Paulo, Brazil. Transfusion. 1999;39:1152-3.

167. Kupek EJ. Residual transfusion risk for hepatitis B and C in southern Brazil, 1991-99. J Viral Hepat. 2001;8:78-82. 
168. Di Pietro MSZ. Direito administrativo. 11a edição. São Paulo: Atlas; 1999. p. 505. 